\title{
Investigação da relação entre parâmetros da compactação giratória e de deformação permanente em misturas asfálticas densas
}

Dissertação apresentada à Escola de
Engenharia de São Carlos da Universidade
de São Paulo, como parte dos requisitos
para a obtenção do título de Mestre em
Ciências, Programa de Pós Graduação em
Engenharia de Transportes.

Área de Concentração: Infraestrutura de Transportes.

Orientadora: Profa ${ }^{a}$. Dra . Ana Paula Furlan

São Carlos

2014 
AUTORIZO A REPRODUCÃO TOTAL OU PARCIAL RESTE TRABALHO, POR QUALQUER MEIO ĆONVENCIONAL OU ELETRÓNICO, PARA FINS DE ESTUDO E PESQUISA, DESDE QUE CITADA A FONTE.

Soares, Jessica Santiago

Investigaçio da relaçlo entre parametros da compactaçlo giratoria e de deformaça permanente en misturas asfalticas densas / Jessica Santiago Soares: orientadora Ana Paula Furlan. Slo Carlos, 2014.

Dissertaçlo (Mestrado) - Programa de Pos-Graduaçăo em Engenharia de Transportes e Area de Concentraçlo em Infra-Estrutura de Transporte -- Escola de Engenharia de S9o Carlos da Universidade de S9o Paulo, 2014.

1. Compactaço giratoria. 2. Deformaço permanente. 3. Creep estático e dinamico . 4. Misturas asfílticas. 5. Asfaltos convencionais e modificados por polfmero SBS. 6. Cal hidratada. I. Título. 


\section{FOLHA DE JULGAMENTO}

Candidata: Engenheira JESSICA SANTIAGO SOARES.

Título da dissertação: "Investigação da relação entre parâmetros da compactação giratória e deformação permanente de misturas asfálticas densas".

Data da defesa: 08/08/2014

Comissão Julgadora:

Profa. Dra. Ana Paula Furlan (Orientadora)

(Escola de Engenharia de São Carlos/EESC)

Profa. Dra. Lilian Tais de Gouveia

(Universidade Estadual de Ponta Grossa/PR)

Prof. Dr. Glauco Túlio Pessa Fabbri

(Escola de Engenharia de São Carlos/EESC)
Resultado:
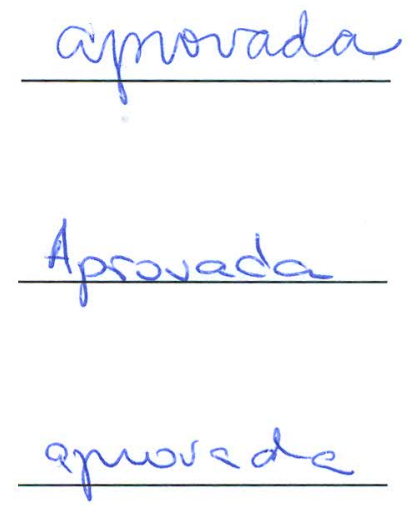

Coordenador do Programa de Pós-Graduação em Engenharia de Transportes: Prof. Associado Paulo César Lima Segantine

Presidente da Comissão de Pós-Graduação:

Prof. Associado Paulo César Lima Segantine 
Dedico esta dissertação à minha família: Maria Helena, Dionel, Andressa e André. Vocês são a razão da minha vida. 



\section{A}

Primeiramente a Deus, por me guiar, iluminar, fortalecer, abençoar e por muitas vezes me levantar;

Aos meus pais, por não medirem esforços para me educar para a vida e para os desafios, por valorizarem a formação acadêmica e por acreditarem no meu potencial. Obrigada ainda por todo amor que me foi dado;

Aos meus irmãos e ao Leandro, pela paciência, pelos incentivos, pelas palavras amigas e por todo carinho nos momentos mais difíceis;

À minha tia Neuza, por ser uma segunda mãe para mim e por sempre estar ao meu lado e da minha família ao longo desta jornada;

À memória da minha avó Amália, por todo o carinho e amor inabalável, que ainda é presente na minha vida;

À minha orientadora Prof. Dra. Ana Paula Furlan, pelo suporte recebido neste trabalho e por todas as críticas, que me fizeram amadurecer nas vidas pessoal e acadêmica. Agradeço também pela amizade e por me guiar na realização deste projeto profissional;

À querida Maria José Zagatto Penha, pela presença amiga e por ser esta pessoa generosa. Obrigada pela ajuda prestada quando necessitei;

Aos docentes do STT, pelos ensinamentos e experiências compartilhadas, que tanto enriquecem a formação acadêmica;

Aos técnicos do Laboratório de Estradas do Departamento de Transportes da EESC/USP, Antonio Carlos Gigante, João D. Pereira Filho e Paulo Toyama. E aos funcionários do STT, Alexandre, Elisabeth, Heloísa, Magali, Paulinho e Toco, pela amizade e por toda atenção despendida;

Aos queridos colegas e amigos do STT e em especial à Andressa, Cecília, Marcela, Suzana e Thais. Pelas conversas, risadas, companhia e por diversas vezes atenuarem a saudade da família. Agradeço ainda novamente à Andressa, por todas as elucidações e sugestões à pesquisa;

Às queridas amigas Heloisa Helena, Rosana e Tauany, pelo estímulo e torcida;

E por fim, ao CNPq pela bolsa de estudo concedida para a realização desta pesquisa pelo período de 2 anos. 

Não há fatos eternos, como não há verdades absolutas.

(Friedrich Nietzsche) 



\section{RESUMO}

Soares, J. S. Investigação da relação entre parâmetros da compactação giratória e de deformação permanente em misturas asfálticas densas. 2014. 98 p. Dissertação (Mestrado) - Escola de Engenharia de São Carlos, Universidade de São Paulo, São Carlos, 2014.

Esta pesquisa tem como objetivo estudar a relação entre parâmetros de compactação e de deformação permanente à luz dos ensaios de compactação giratória Superpave ${ }^{\circledR}$ e de ensaios de compressão uniaxial estática e dinâmica. Foram estudadas 8 misturas asfálticas com a mesma granulometria (Faixa C) e tipo de agregado mineral (granito) porém variou-se o ligante asfáltico (CAP 50/70 e CAP 50/70+SBS), o volume de vazios ( $4 \%$ e $7 \%$ ) e a adição de cal hidratada. A partir dos resultados do ensaio de compactação observou-se que a inclinação das curvas de compactação das misturas compactadas a $7 \%$ foram mais acentuadas do que as de $4 \%$ e os parâmetros incidentais deste ensaio foram sensíveis à presença de cal e à variação do asfalto das misturas testadas. Quanto aos resultados dos ensaios de creep estático e dinâmico, notou-se que as misturas com $\mathrm{Vv}$ de $4 \%$ e as com asfalto modificado apresentam menor suscetibilidade à deformação permanente, no entanto, essas vantagens do asfalto modificado foram observadas somente nos ensaios de creep dinâmico. No que se refere às relações entre os parâmetros de compactação e de deformação permanente, os ajuste não se mostraram promissores como verificado pela qualidade dos ajustes $\left(R^{2}\right)$ exceto para algumas relações com CDI e TDI $\mathrm{m}$.

Palavras chave: compactação giratória, deformação permanente, creep estático e dinâmico, misturas asfálticas, asfaltos convencional e modificado por polímero SBS e cal hidratada. 


\begin{abstract}
SOARES, J.S. Investigation of relationship between the gyratory compaction and rutting parameters of asphalt mixtures. 2014. 98 p. Dissertação (Mestrado) Escola de Engenharia de São Carlos, Universidade de São Paulo, São Carlos, 2014.

This research aims to study relations between compaction and permanent deformation by means of Superpave ${ }^{\circledR}$ gyratory compaction and static and dynamic creep tests. Thus, eight asphalt mixtures were evaluated which were composed by same type (granite) and gradation (dense) of mineral aggregate but two types of asphalt binder (Pen 50/70 AC and Pen 50/70+SBS AC), two different levels of air voids $(4 \%$ and $7 \%)$ and the addition of hydrated lime. Compaction results indicated that curve slopes of $7 \%$ air void asphalt mixtures were stronger than the $4 \%$ ones, and compaction parameters were sensitive to lime addition and asphalt type change. Static and dynamic creep test results indicated that $4 \%$ air void and modified asphalt mixtures presented lower susceptibility to rutting, but, these modified asphalt advantages were observed only in dynamic creep tests. In regard to relation between compaction and rutting parameters, linear models did not fit accurately, excepting some CDI and $\mathrm{TDI}_{\mathrm{m}}$ ones.
\end{abstract}

Key words: gyratory compaction, rutting, static and dynamic creep tests, asphalt mixtures, conventional and SBS polymer modified asphalts and hydrated lime. 


\section{LISTA DE FIGURAS}

Figura 1- llustração esquemática simplificada mostrando a formação de trilha de rodas.

Figura 2 - Efeito do percentual de ligante em uma mistura asfáltica com a mesma granulometria (Adaptado de Gardete, 2006).

Figura 3 - Esquema da estrutura da mistura asfáltica antes da compactação final (Adaptado de Micaelo, 2008).

Figura 4 - Esquema da estrutura da mistura asfáltica após a compactação final (Adaptado de Micaelo, 2008).

Figura 5 - Prensa giratória do Texas (Harman et al., 2002). 34

Figura 6 - Esquema do CGS (Motta et al., 1996). 38

Figura 7 - Curva de densificação obtida na compactação giratória Superpave®......39

Figura 8- Representação gráfica do índice CDI (Nascimento, 2008). 41

Figura 9 - Representação gráfica do índice TDI (Nascimento, 2008). 41

Figura 10 - Esquema 3-2 de Pine (1997) - (Adaptado de Prowell and Brown, 2007).

Figura 11 - Esquema 3-2-2 de Vavrik e Carpenter (1998) - (Adaptado de Prowell and Brown, 2007).

Figura 12 - Curva de creep estático (Moura, 2010).

Figura 13 - Curva de fluência de uma mistura asfáltica.

Figura 14 - Curva de fluência de uma mistura asfáltica.

Figura 15 - Relação entre Flow Number versus afundamento de trilha de roda das pistas de Minnesota (Witczak et al., 2002). 50

Figura 16 - Faixa C do DNIT, limites superior, inferior e centro de faixa.. 52

Figura 17 - Curva da viscosidade versus temperatura dos ligantes asfálticos estudados. .54

Figura 18 - Compactador Giratório Superpave $₫$. 57

Figura 19 - Representação do cálculo dos parâmetros CDI e TDIm. 60

Figura 20 - Carregamento creep estático. 
Figura 21 - Exemplo de tela do ensaio de Creep Estático em Labview 7.1® 63

Figura 22 - Tempo de carregamento e descarregamento do creep dinâmico. 64

Figura 23 - Curvas de densificação para misturas com Vv $=4 \%$. 68

Figura 24 - Curvas de densificação para misturas com Vv $=7 \%$. 68

Figura 25 - Valores médios para inclinação da curva de densificação. 69

Figura 26 - Valores de CDI das 8 misturas asfálticas testadas. 71

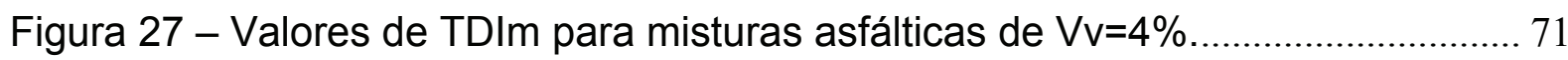

Figura 28 - Valores médios de LP para as misturas asfálticas de $\mathrm{Vv}=4 \%$............. 74

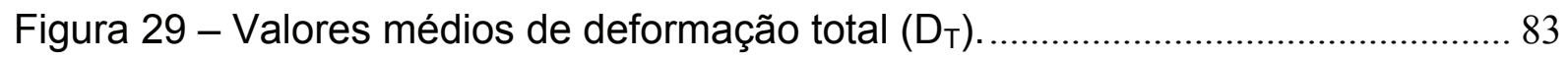

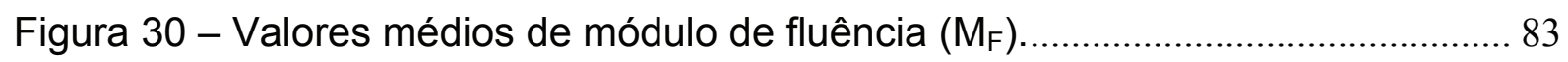

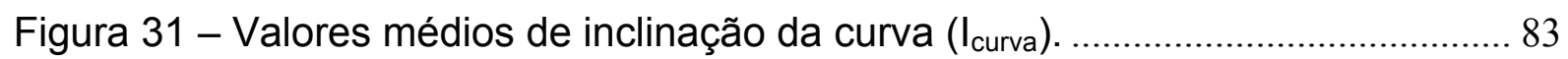

Figura $32-I_{\text {curva }}$ de compactação versus parâmetros de creep estático. .................... 88

Figura 33 - Correlações entre CDI e parâmetros de creep estático. ........................... 90

Figura 34 - Correlações entre CDI e parâmetros de creep estático. ........................... 91

Figura 35 - Ajuste linear para correlações entre TDIm e parâmetros de creep estático.

Figura 36 - Correlações entre CDI e parâmetros de creep estático.

Figura 37 - Correlações entre $I_{\text {curva }}$ de compactação e parâmetros de creep dinâmico.

Figura 38 - Correlações entre CDI e creep dinâmico. 95

Figura 39 - Correlações entre TDIm e de creep dinâmico. 96

Figura 40 - Correlações entre LP e de creep dinâmico. 97 


\section{LISTA DE TABELAS}

Tabela 1 - Fatores que atuam no afundamento de trilha de roda nos revestimentos asfálticos (Adaptado de Mahmoud e Bahia, 2004).

Tabela 2 - Histórico da evolução dos compactadores giratórios (Adaptado de Harman et al., 2002).

Tabela 3 - Valores de CDI e TDI sugeridos por Nascimento ( 2008) para rodovias brasileiras.

Tabela 4 - Alturas do corpo de prova no compactador giratório para determinação do LP 3-3-3 ou3-2.

Tabela 5 - Especificações de tempos de carregamento e repouso, tensão de carregamento, altura do corpo de prova e temperatura (Adaptada de Mugayar, 2004)

Tabela 6 - Quadro resumo dos ensaios de caracterização dos agregados.

Tabela 7 - Valores obtidos de temperatura de usinagem e compactação. 54

Tabela $8-\mathrm{N}$ de projeto segundo o tráfego a ser simulado. 58

Tabela 9 - Nomenclatura das misturas asfálticas da pesquisa. 67

Tabela 10 - Valores médios para inclinação da curva de compactação.

Tabela 11 - Valores de CDI e TDIm para misturas asfálticas com Vv=4\%. 70

Tabela 12 - Valores de CDI para misturas asfálticas com $V_{v}=7 \%$. 71

Tabela 13 - Valores médios de LP para as misturas asfálticas de $\mathrm{Vv}=4 \%$. .73

Tabela 14 - Volumes de vazios inicial/no LP/final, na compactação. 74

Tabela 15 - Valores médios dos parâmetros de ensaio de Creep Estático $40^{\circ} \mathrm{C}$......76

Tabela 16 - Valores médios dos parâmetros de ensaio de Creep Estático $50^{\circ} \mathrm{C}$......76

Tabela 17 - Quadro resumo das análises realizadas sobre os efeitos do aumento do volume de vazios de $4 \%$ para $7 \%$.

Tabela 18 - Quadro resumo das análises realizadas sobre os efeitos da adição do SBS ao ligante asfáltico.

Tabela 19 - Quadro resumo das análises realizadas sobre os efeitos da adição de cal nas misturas asfálticas. 
Tabela 20 - Valores médios dos parâmetros de ensaio de Creep Dinâmico $40^{\circ} \mathrm{C} \ldots 82$

Tabela 21 - Valores médios dos parâmetros de ensaio de Creep Dinâmico $50^{\circ} \mathrm{C} \ldots 82$

Tabela 22 - Resumo dos efeitos do aumento do volume de vazios de $4 \%$ para $7 \% .85$

Tabela 23 - Resumo dos efeitos da adição de SBS ao ligante asfáltico..................... 86

Tabela 24 - Resumo dos efeitos da adição de cal nas misturas asfálticas. ............... 87

Tabela 25 - Classificação proposta para as correlações............................................. 88 


\section{SÍMBOLOS E ABREVIATURAS}

AASHTO - American Association of State Highway and Transportation Officials ASTM - American Society for Testing and Materials

ATR - Afundamento de trilha de roda

BRP - Borracha reciclada de pneu

CAP - Cimento asfáltico de petróleo

CDI - Construction Densification Index

CE - Condições experimentais

CEI - Contact Energy Index

CFI - Compaction Force Index

CGS - Compactador giratório Superpave ${ }^{\circledR}$

CP - Corpo de prova

DNER - Departamento Nacional de Estradas de Rodagem

DNIT - Departamento nacional de infraestrutura de transporte

DOT - Departament of Transportation

DP - Deformação permanente

$D_{T}-$ Deformação total

$\varepsilon_{1 \mathrm{t}}-$ Deformação recuperável

$E_{c}$ - Módulo de creep dinâmico

EVA - Etileno acetato de vinila

$\varepsilon_{\text {rel }}-$ Deformação relativa

$\varepsilon_{\text {rel(t) }}-$ Deslocamento relativo

$\varepsilon_{\mathrm{vp}}-$ Deformação não recuperável

FHWA - Federal Highway Admnistration

$\mathrm{FN}$ - Flow number 
FT - Flow time

$\mathrm{G}_{\mathrm{mm} \text { - Densidade máxima teórica }}$

$\mathrm{h}_{\mathrm{cp}-}$ Altura do corpo de prova

HMA - Hot mix asphalt

$I_{\text {curva }}$ - Inclinação da curva

LP - Locking point

LVDT - Linear Variable Differential Transducer

$M_{F}$ - Módulo de fluência

NCHRP -National Cooperative Highway Research Program

$\mathrm{N}_{\text {ini }}-$ Número de giros inicial

$\mathrm{N}_{\mathrm{lp}}$ - Número de giros no locking point

$\mathrm{N}_{\text {proj }}$ - Número de giros de projeto

$\mathrm{N}-\mathrm{SR}_{\max }$ - Número de giros em relação à tensão máxima

PG - Performance grade

PTA - Ponto de travamento dos agregados

PPA - Ácido polifosfórico

SHRP - Strategic Highway Research Program

SBS - Estireno- butadieno- estireno

SBR - Borracha- estireno -butadieno

SUPERPAVE - Superior Performing Asphalt Pavements

TDI - Traffic Densification Index

TDI $_{m}$ - Traffic Densification Index Modified

TFI - Traffic Force Index

$\mathrm{T}_{\mathrm{i}}-$ Teor de ligante asfáltico inicial

$\sigma-$ Tensão aplicada

Vv - Volume de vazios 


\section{ÍNDICE}

\section{INTRODUÇÃO}

1.1. Considerações iniciais.......................................................................... 19

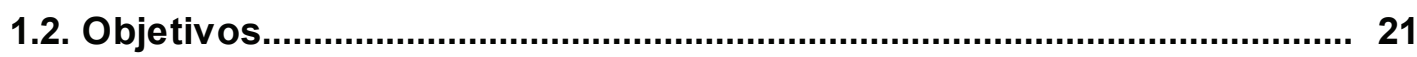

1.3. Organização do trabalho.......................................................................... 22

\section{REVISÃO DE LITERATURA}

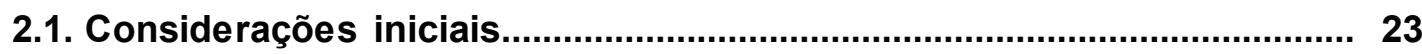

2.2. Deformação permanente....................................................................... 23

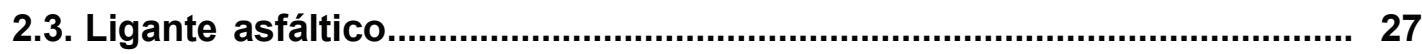

2.4. Fíler de cal hidratada............................................................................ 29

2.5. Compactação e compactabilidade de misturas asfálticas........................ 31

2.6. Compactação giratória em misturas asfálticas...................................... 33

2.7. Compactador giratório Superpave ${ }^{\circledR}$ (CGS).............................................. 36

2.8. Parâmetros oriundos da compactação....................................................... 39

2.8.1. Construction and Traffic Densification Index (CDI - TDI) .................... 40

2.8.2. Locking Point................................................................................ 43

2.9. Ensaios de previsão de deformação permanente.................................. 45

2.9.1. Creep estático........................................................................... 46

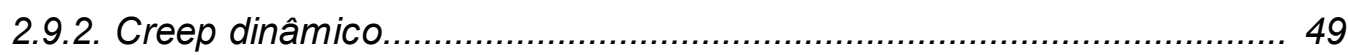

3. MATERIAIS

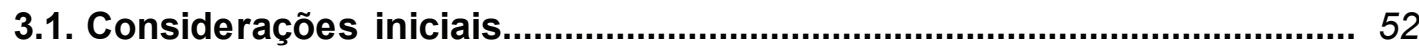

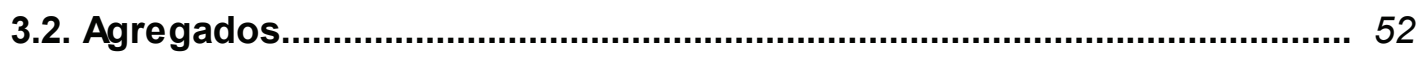

3.3. Ligante asfáltico.......................................................................... 53

3.4. Cal hidratada............................................................................................ 55

4. MÉTODOS

4.1. Considerações iniciais.......................................................................... 56

4.2. Mistura asfáltica................................................................................ 57

4.3. Processamento da curva de compactação................................................ 56

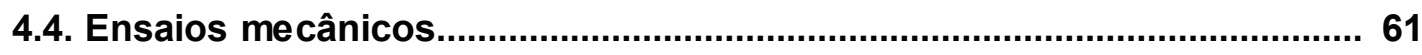

4.4.1. Fluência por compressão uniaxial estática (creep estático).................. 61

4.4.2. Fluência por compressão uniaxial dinâmica (creep dinâmico).............. 63

4.5. Análise e tratamento dos dados..................................................................6 64

\section{APRESENTAÇÃO E ANÁLISE DE DADOS}

5.1. Considerações iniciais............................................................................6 66

5.2. Parâmetros oriundos da compactação..................................................... 67

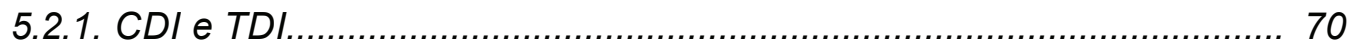

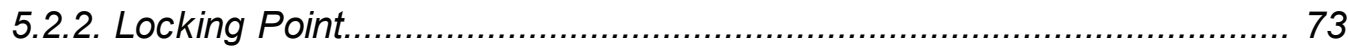

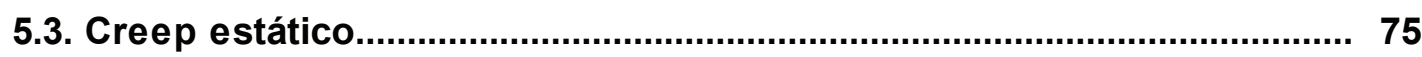




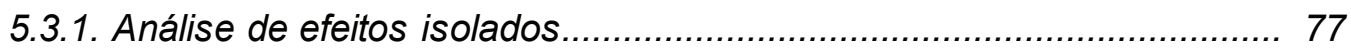

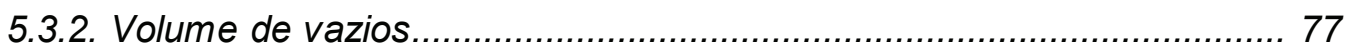

5.3.3. Ligante asfáltico..................................................................... 79

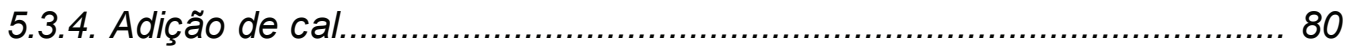

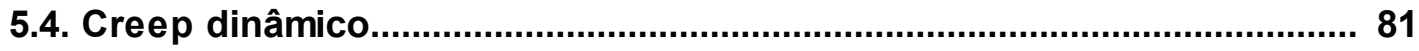

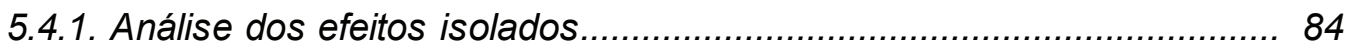

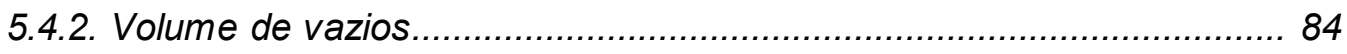

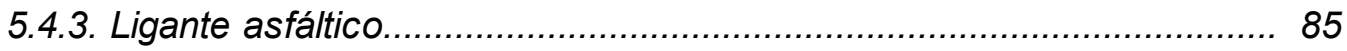

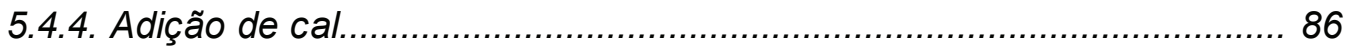

5.5. Relações entre compactação e deformação permanente ........................ 87

5.5.1. Compactação versus creep estático............................................... 88

5.5.5. Compactação versus creep dinâmico.............................................. 94

\section{CONCLUSÕES E SUGESTÕES}

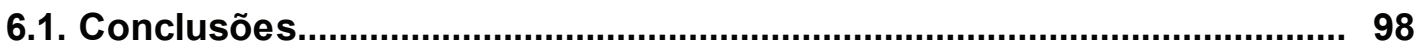

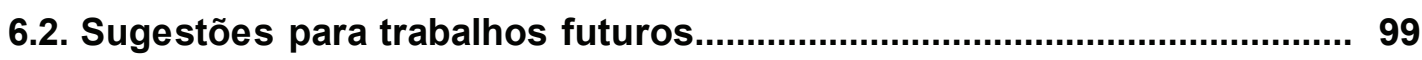

$\begin{array}{ll}\text { 7. REFERÊNCIAS BIBLIOGRÁFICAS } & 100\end{array}$

ANEXO 1 - Valores das inclinações das curvas de compactação

ANEXO 2 - Valores de locking point das misturas asfáticas

ANEXO 3 - Valores de CDI e TDI das misturas asfálticas

ANEXO 4 - Valores de creep estático na temperatura de $40^{\circ} \mathrm{C}$

ANEXO 5 - Valores de creep estático na temperatura de $50^{\circ} \mathrm{C}$

ANEXO 6 - Valores de creep dinâmico na temperatura de $40^{\circ} \mathrm{C}$

ANEXO 7 - Valores de creep dinâmico na temperatura de $50^{\circ} \mathrm{C}$ 
CAPÍTULO 1

\section{INTRODUÇÃO}

\subsection{CONSIDERAÇÕES INICIAIS}

As solicitações de cargas de tráfego são responsáveis pelo desenvolvimento de um dos principais mecanismos de degradação dos pavimentos asfálticos: as deformações permanentes nas trilhas de roda. Além de danificar o pavimento e prejudicar a serventia da estrada, afeta a segurança da via aumentando os riscos de aquaplanagem, uma vez que a água pode se acumular nas depressões.

Este mecanismo de degradação ocorre por variados motivos como, por exemplo, por deformações plásticas excessivas do subleito ou pela baixa estabilidade da capa asfáltica. Quando a deformação permanente é um problema da falta de suporte do subleito, as soluções são mais difíceis, onerosas e trabalhosas, visto que são necessárias intervenções em mais de uma camada da estrutura do pavimento. No entanto, quando o afundamento em trilha de roda (ATR) é devido a problemas com as mistura asfáltica, a solução é melhorá-la buscando prevenir o desenvolvimento do defeito, com o emprego de distribuições granulométricas adequadas, ou de ligantes asfálticos mais duros, ou ainda a combinação de ambas alternativas.

Uma gama de literaturas recomenda a incorporação de aditivos a fim de melhorar as características mecânicas e até reológicas das misturas asfálticas. Entre os mais usados e mais aceitos até o momento estão a cal hidratada e os polímeros. A cal hidratada contribui significativamente para o enrijecimento do mástique (combinação entre ligante asfáltico, fíler e ar) e em decorrência deste fenômeno torna a mistura asfáltica mais resistente ao desenvolvimento de deformações permanentes em altas temperaturas. Já alguns polímeros podem tornar o ligante asfáltico mais rígido e deste modo melhoram a resistência a deformações plásticas.

Nesse sentido, pode-se dizer que a dosagem das misturas asfálticas tem influência decisiva no seu bom desempenho. Atualmente, com o método de dosagem Superpave ${ }^{\circledR}$ (Superior Performing Asphalt Pavements), são observadas técnicas mais sofisticadas de seleção e controle de materiais e de produção de 
misturas asfálticas se comparado à metodologia Marshall, que é a mais utilizada até o momento no Brasil.

Uma das principais diferenças entre os dois métodos de dosagem está na seleção dos materiais que no método Marshall, baseia-se nas propriedades volumétricas, enquanto que no método de dosagem Superpave ${ }^{\circledR}$ além destas propriedades, os fatores clima e tráfego também são considerados. O modo de compactação dos corpos de prova também é diferente nesses métodos de dosagem. Na dosagem Marshall se utiliza a compactação por impacto, já na metodologia Superpave ${ }^{\circledR}$ a compactação ocorre por amassamento com o emprego de um compactador giratório. Proweel e Brown (2007) destacam que a compactação realizada pelo compactador giratório Superpave ${ }^{\circledR}$ geralmente leva a um menor teor de asfalto na mistura do que a compactação Marshall. O que leva a crer que haja excesso de ligante em misturas asfálticas projetadas pelo método Marshall em função de uma energia menor envolvida no processo. Considerando que haverá excesso de asfalto na mistura no método Marshall, pode-se prever uma maior tendência ao desenvolvimento de afundamentos nas trilhas de roda.

No que diz respeito aos agregados, o arranjo do esqueleto pétreo pode dar uma indicação da resistência da mistura asfáltica e, consequentemente, do seu comportamento mecânico. Muitos estudos vêm tentando relacionar as propriedades dos agregados com o desempenho das misturas. No entanto, esta não é uma questão fácil de ser respondida, pois uma única propriedade desse material pode influenciar em características fundamentais das misturas, acarretando em alterações no todo (GOUVEIA, 2006).

Este tipo de avaliação a respeito da distribuição granulométrica e dosagem dos ligantes asfálticos não são simples e é uma tentativa de obter uma previsão de comportamento do produto mistura asfáltica. Bahia et al., (1998) propôs dois índices a partir das curvas de compactação de misturas asfálticas: Construction Densification Index (CDI) e Traffic Densification Index (TDI). Admite-se que estes índices são capazes de representar o comportamento das misturas asfálticas durante a construção da pista e a vida de serviço. Mahmoud e Bahia (2004) afirmam que estes parâmetros são capazes de refletir a trabalhabilidade e a resistência à deformação permanente das misturas asfálticas. Um valor elevado de CDI para uma determinada mistura asfáltica requer aplicação de grande quantidade 
de energia para compactar durante a construção. Enquanto que são desejáveis valores elevados de TDI para as misturas asfálticas, pois ao longo da vida de serviço acredita-se que será exigido um alto volume de tráfego para compactar.

No ano de 1997, o Departamento do Estado de Illinois introduziu o conceito de Locking Point, que seria uma alternativa de substituição do número de giros de projeto $\left(\mathrm{N}_{\text {proj }}\right)$. Este conceito defendido por Pine tem como maior objetivo evitar o excesso de compactação nas misturas asfálticas, evitando assim a degradação dos agregados minerais. No número de giro de locking point (LP) ou do português ponto de travamento dos agregados (PTA), é defendido que o LP pode ser usado para representar a aplicação da energia para alcançar um nível de compactação e resistência à deformação permanente de uma mistura asfáltica (LEIVA e VILLACORTA, 2007; PROWELL e BROWN , 2007).

\subsection{OBJETIVOS}

O objetivo principal desta pesquisa é estudar a relação entre parâmetros de compactação e de deformação permanente, com base em resultados de ensaios de compactação giratória Superpave ${ }^{\circledR}$ e de fluência por compressão axial, respectivamente.

Este estudo tem também outros objetivos secundários:

i) Avaliar e quantificar a influência de certos parâmetros como: índice de volume de vazios, ligante asfáltico e adição de cal; podem exercer na curva de compactação e de fluência das misturas asfálticas.

ii) Utilizar o conceito de Locking Point para avaliar as misturas asfálticas quanto à rigidez.

iii) Relacionar os parâmetros incidentais do ensaio de compactação (Locking Point, Inclinação da Curva de compactação e CDI e TDIm) e os parâmetros obtidos nos ensaios de fluência por compressão uniaxial estático e dinâmico (deformação total e recuperável, recuperação e módulo de fluência). 


\subsection{ORGANIZAÇÃO DO TRABALHO}

Este trabalho é apresentado em 6 capítulos, sendo o Capítulo 1 da introdução e objetivos. No Capítulo 2 é apresentada a revisão de literatura, onde são discorridos assuntos pertinentes à compactação e à deformação permanente em misturas asfálticas. São também discutidos temas importantes relacionados aos materiais constituintes de misturas asfálticas, com ênfase nos seus efeitos sobre a compactação e a deformação permanente. É apresentado um breve histórico sobre o Compactador Giratório Superpave ${ }^{\circledR}$, assim como os parâmetros da curva de densificação e parâmetros obtidos nos ensaios de fluência por compressão axial estático e dinâmico. No Capítulo 3, estão descritos os materiais utilizados no estudo. No Capítulo 4 está descrito o método experimental desenvolvido na pesquisa, bem como o procedimento para o processamento das curvas de densificação e curvas dos ensaios de compressão uniaxial estática e dinâmica. No Capítulo 5 são apresentados os resultados dos ensaios e são feitas as análises dos dados. $O$ Capítulo 6 contém as conclusões da pesquisa e são feitas sugestões para trabalhos futuros. 
CAPÍTULO 2

\section{REVISÃO DE LITERATURA}

\subsection{CONSIDERAÇÕES INICIAIS}

Neste capítulo são discutidos assuntos pertinentes ao desenvolvimento do presente estudo. Primeiramente foi feita uma revisão de literatura sobre a compactação em misturas asfálticas, e fatores que influenciam o processo, em seguida foram discutidas as compactações Marshall, Superpave ${ }^{\circledR}$, previsões da compactação em campo, além de um breve histórico do compactador giratório Superpave ${ }^{\circledR}$.

São abordados também neste contexto os parâmetros extraídos da curva de compactação como: Densification Index (CDI) e Traffic Densification Index (TDI) e locking point (LP). Em seguida é feita uma revisão sobre a deformação permanente em misturas asfálticas, onde se discute também a respeito dos efeitos dos aditivos que visam melhorar o comportamento das misturas asfálticas, além de discorrer a respeito dos ensaios de creep estático e creep dinâmico, que são ferramentas de previsão de deformação permanente em misturas asfálticas.

\subsection{DEFORMAÇÃO PERMANENTE}

A deformação permanente é caracterizada por depressões longitudinais que ocorrem devido a deformações plásticas ao longo da trilha de roda (Figura 1). Este defeito é comum em revestimentos asfálticos de rodovias brasileiras, seja por problemas da mistura asfáltica, como baixa resistência ao cisalhamento ou alta suscetibilidade térmica, ou por reflexo de densificação ou rupturas localizadas nas camadas subjacentes e/ou no subleito. 


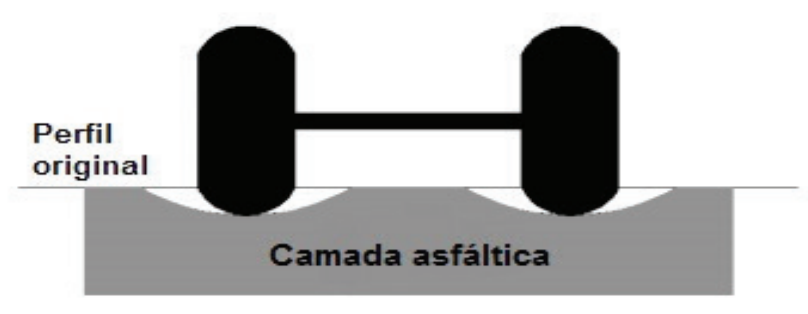

Figura 1- llustração esquemática simplificada mostrando a formação de trilha de rodas.

Segundo Witczak (2007), a deformação permanente é categorizada em três tipos, definidos por suas respectivas causas: compressão vertical, fluência lateral ou movimento plástico e deformação mecânica.

A) Compressão vertical: A densificação dos materiais geralmente é causada pelo excessivo volume de vazios e/ou inadequada compactação da mistura asfáltica, o que permite que a capa asfáltica e as demais camadas subjacentes compactem quando solicitadas pelas cargas de tráfego.

B) Fluência lateral ou movimento plástico: Caracteriza-se por uma depressão próxima ao centro da trilha de roda que, ao contrário da deformação permanente causada por compressão vertical, é acompanhada de sobrelevação lateral. Geralmente, as depressões formadas resultam em deformações permanentes de níveis moderado a alto. Este defeito ocorre em misturas asfálticas que possuem baixa resistência ao cisalhamento ou que sofreram compactação inadequada.

C) Deformação mecânica: Resulta da baixa resistência (e/ou ruptura localizada) da base, sub-base e/ou subleito em combinação com misturas asfálticas muito rígidas. É acompanhada por uma fissuração longitudinal típica na superfície do pavimento.

O tráfego é um fator importante no desenvolvimento da deformação permanente, principalmente a velocidade que ocorrem estas solicitações de carga. Velocidades baixas de carga de tráfego são mais prejudiciais, pois correspondem a ter a carga sobre uma determinada zona do pavimento durante um maior intervalo de tempo. Desta forma as deformações obtidas são superiores, existindo uma parcela de deformação irreversível também superior (GARDETE, 2006). 
Outro fator provável causador de deformação permanente é a inapropriada seleção do teor de ligante asfáltico. Para cada mistura asfáltica há de ser dosada a quantidade de ligante asfáltico suficiente por garantir uma ligação satisfatória do arranjo pétreo. Deve-se evitar uma quantidade excessiva de ligante asfáltico, pois a mistura asfáltica pode se deformar com maior facilidade quando solicitada, tornandose uma mistura de baixa resistência à deformação permanente, como ilustra a Figura 2. Em vias de tráfego leve é recomendado um percentual de teor de asfalto maior que em vias de tráfego pesado, a fim de auxiliar na durabilidade do concreto asfáltico. O motivo da recomendação de se evitar a alta porcentagem de asfalto em vias de tráfego intenso é devido ao problema de exsudação, que é decorrente da alta densificação da mistura asfáltica sob altas temperaturas (MAHMOUD e BAHIA, 2004; MUGAYAR, 2004; GARDETE, 2006).
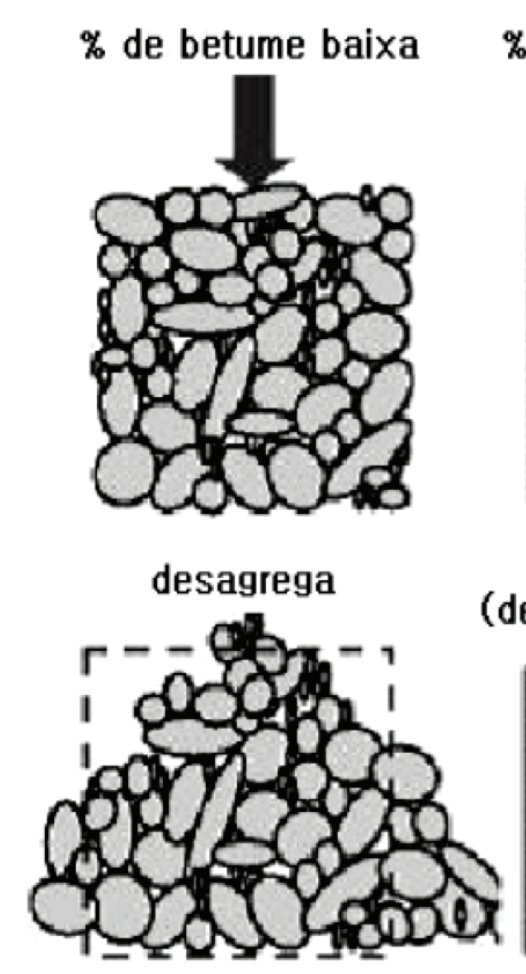

\% de betume ótima

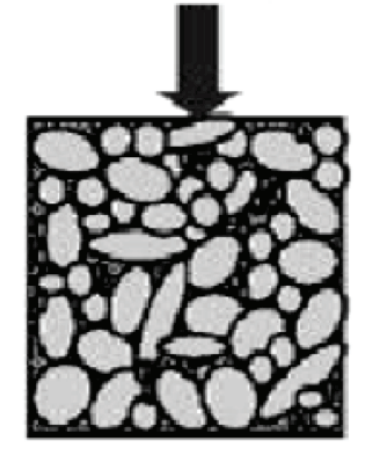

suporta a carga

(deformação aceitável)

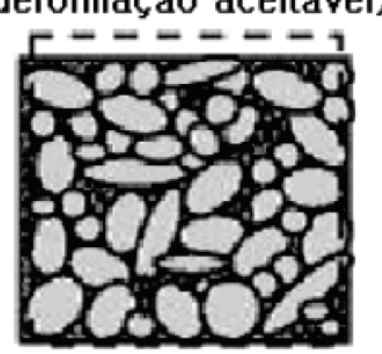

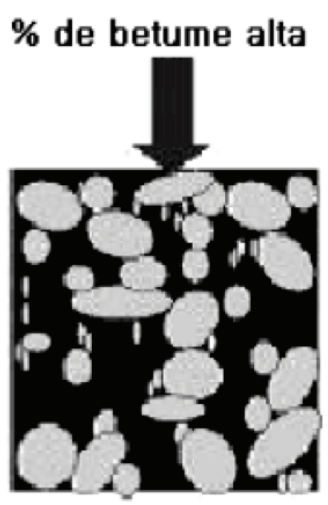

deformação excessiva

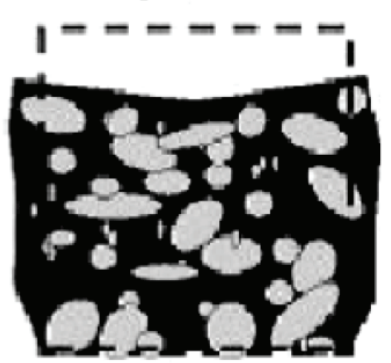

Figura 2 - Efeito do percentual de ligante asfáltico em uma mistura asfáltica com a mesma distribuição granulométrica (Adaptado de Gardete, 2006).

Numa escala de importância, é entendido que os agregados exercem maior influência na resistência à deformação permanente se comparados ao ligante asfáltico, a Federal Highway Admninistration (FHWA) chega a fixar em 80\% o percentual de responsabilidade dos agregados responderem na prevenção do 
desenvolvimento da deformação permanente. De modo geral, misturas asfálticas compostas com agregados de textura rugosa, forma angular e mais cúbicos resultam em melhor intertravamento do esqueleto pétreo e maior resistência ao cisalhamento. Além desses fatores, também a graduação dos agregados é importante, misturas de graduação densa ou contínua geralmente mostram uma tendência de atenuar os efeitos da deformação permanente, devido ao maior contato entre as partículas e, consequentemente, menor volume de vazios. Alguns estudos indicam ainda a melhora na resistência à deformação permanente em misturas asfálticas com mais agregados grossos, ou seja, com agregados de diâmetro máximo nominal maiores. Contudo, as misturas de graduação aberta se deformam com maior facilidade do que as de graduação densa (MAHMOUD e BAHIA, 2004; MUGAYAR, 2004; ONOFRE, 2012).

Quando a redução no volume de vazios nas misturas asfálticas ocorre pelo aumento do teor de asfalto, há um aumento da tendência à deformação permanente. A viscosidade do ligante também pode ter relação com a deformação permanente. Os asfaltos menos viscosos resultam em misturas asfálticas com menor rigidez que, consequentemente, podem ser mais suscetíveis a deformações irrecuperáveis (MAHMOUD e BAHIA, 2004).

Nascimento (2008), estudando o comportamento à deformação permanente de misturas densas, concluiu que o comportamento do ligante asfáltico exerce pouca influência na resistência das misturas à deformação permanente se comparado ao esqueleto pétreo, além de não garantir a estabilidade do material. Caso o esqueleto pétreo não suporte as cargas, dificilmente o ligante asfáltico compensará esta deficiência. $\mathrm{O}$ autor também concluiu que misturas com ligantes asfálticos de maior consistência e esqueleto pétreo deficiente tiveram desempenho inferior ao de misturas com ligantes de menor consistência com esqueleto pétreo projetado adequadamente.

Para Bernucci et al. (2007) o desenvolvimento da deformação permanente pode ser evitado por meio da seleção adequada dos materiais, compactação satisfatória, elaboração de um projeto de pavimento satisfatório e rigoroso controle de qualidade de construção.

Anderson et al. (2002), estudando a relação entre deformação permanente dos pavimentos em serviço e as propriedades mensuráveis da mistura asfáltica 
durante a compactação no CGS, observou que o parâmetro número de giros na tensão de cisalhamento máximo $\left(\mathrm{N}-\mathrm{SR}_{\mathrm{Max}}\right)$ durante a compactação poderia prever o desempenho das misturas asfálticas quanto à rigidez e à deformação permanente.

Em suma, a deformação permanente nas camadas asfálticas é um fenômeno que depende de um conjunto de fatores. Agregado, ligante asfáltico, propriedades volumétricas, efeitos do clima e tráfego podem afetar o desempenho global das misturas asfálticas. Ocorre ainda também que estas propriedades mudam ao longo do tempo, devido ao envelhecimento, até que a mistura asfáltica chegue ao fim do seu ciclo de vida útil. Mahmoud e Bahia (2004) compilaram os fatores influentes e seus efeitos na resistência ao afundamento em trilhas de rodas, como apresentado na Tabela 1.

Tabela 1 - Fatores que atuam no afundamento de trilha de roda nos revestimentos asfálticos (Adaptado de Mahmoud e Bahia, 2004).

\begin{tabular}{c|c|c|c}
\hline & Fator & Variação do fator & Resistência ao ATR \\
\hline \multirow{3}{*}{ Agregados } & Textura superficial & Lisa para rugosa & Aumento \\
\cline { 2 - 4 } & Granulometria & Descontínua para densa & Aumento \\
\cline { 2 - 4 } & Forma & Arredondada para angular & Aumento \\
\cline { 2 - 4 } & Tamanho & Aumento no tamanho máximo & Aumento \\
\hline \multirow{2}{*}{ Ligante } & Rigidez & Aumento & Aumento \\
\hline \multirow{2}{*}{ Mistura } & Teor de ligante & Aumento & Redução \\
\cline { 2 - 4 } Asfática & Percentual de vazios & Aumento & Redução \\
\cline { 2 - 4 } & VAM & Aumento & Redução \\
\hline
\end{tabular}

\subsection{LIGANTE ASFÁLTICO}

O papel do ligante asfáltico é manter os agregados que constituem o arranjo pétreo unidos, de tal maneira que as partículas não se desloquem, resistindo assim ao esforço cisalhante que ocorre nos pontos de contato dos agregados. Uma das principais características do asfalto é a suscetibilidade à temperatura, de modo que suas propriedades são dependentes da temperatura e a ausência de referência da temperatura de caracterização deste material inviabiliza a interpretação. $\mathrm{O}$ asfalto 
também depende do tempo de carregamento e deste modo os fatores temperatura e carregamento podem ser intercambiados. Assim, um carregamento lento pode simular altas temperaturas e um carregamento rápido pode simular baixas temperaturas (Motta, 1996).

Os asfaltos de maior consistência originam misturas asfálticas mais resistentes à deformação permanente. $O$ fato da intensidade do efeito do asfalto na prevenção da deformação permanente ser menor quando comparado ao efeito dos agregados se deve à suscetibilidade térmica dos asfaltos. Nas temperaturas em que a mistura asfáltica encontra-se suscetível ao desenvolvimento da deformação permanente, o asfalto encontra-se mais próximo do seu ponto de amolecimento e portanto está menos viscoso, perdendo assim sua resistência em relação às solicitações de carga do tráfego (MAHBOUD e LITTLE, 1988; HUBBER, 1999; BERNUCCl et al., 2007; LEIVA, 2007).

Com o intuito de aumentar a viscosidade e melhorar o desempenho dos ligantes menos viscosos à temperaturas de serviço mais elevadas, pode-se recorrer ao uso de modificadores, como a adição de polímeros. Para Bahia et al. (1998), a classe de polímeros elastômeros confere maior elasticidade ao asfalto e, por consequência, torna os pavimentos mais flexíveis, ou seja, como uma melhor resposta à deformação.

Um parâmetro usualmente utilizado na previsão de propriedades elásticas em asfaltos modificados por polímeros é o ângulo de fase. Gradientes menores de ângulos de fase apontam que o asfalto tem maior elasticidade e menor tendência à deformação permanente (NASCIMENTO, 2008).

Valkering et al. (1990) realizaram um dos principais estudos sobre modificação de asfalto com polímero tipo Estireno-Butadieno-Estireno (SBS). Nele verificou-se que misturas com SBS exibiram redução da profundidade da trilha de rodas em relação às misturas com asfalto convencional.

Outros polímeros também tiveram o uso difundido em misturas asfálticas, dentre eles estão: borracha estireno butadieno (SBR) e o copolímero etileno acetato de vinila (EVA). Além desses exemplos, é usual a adição de borracha reciclada de pneu (BRP) para melhorar as propriedades do asfalto, mas a BRP pode ser usada também em substituição ao agregado. 
Leite (1999) empregou a classificação de asfaltos do Superpave ${ }^{\circledR}$ em diversos ligantes modificados com SBS, SBR e EVA, assim como com borracha reciclada (BRP). A adição destes polímeros e da borracha promoveram mudanças na reologia dos asfaltos elevando o performance grade (PG), por exemplo, um asfalto CAP 20 , classificado como PG 64 -16, apresentou classificação PG 76 -28 após a adição de $15 \%$ de BRP. Já um asfalto tipo CAP 40, classificado como PG $70-10$, apresentou classificação PG 76 -28 com a adição de 5,5\% de SBS.

Vale ressaltar que melhorar as propriedades elásticas e de rigidez dos ligantes pela modificação com polímeros não é determinante no que se refere à influência do asfalto na qualidade e na resistência à deformação permanente das misturas asfálticas. Há que se adequar também a quantidade de asfalto, pois estudos comprovam que quando em excesso, potencializa defeitos como a exsudação e os afundamentos nas trilhas de roda.

\subsection{FÍLER DE CAL HIDRATADA}

O filler exerce importantes funções na estrutura da mistura asfáltica, preenche uma parcela dos vazios entre os agregados graúdos nas misturas ou, dependendo da dimensão, forma o mástique (combinação de ligante asfáltico, fíler e ar) e altera as propriedades dos ligantes asfálticos.

A cal hidratada em adição ou substituição do agregado nas misturas asfálticas pode mitigar os danos por umidade. Além do benefício já citado, ela é utilizada com variadas finalidades e por proporcionar múltiplos benefícios, entre eles:

i) o enrijecimento do asfalto e a formação do mástique;

ii) a melhora da resistência ao avanço da ruptura em baixas temperaturas;

iii) a mudança nas propriedades plásticas dos finos com a melhora da estabilidade e da durabilidade da mistura asfáltica;

iv) a alteração favorável da oxidação, interagindo com produtos de oxidação para reduzir seus efeitos deletérios na mistura afáltica;

a redução do efeito da água no descolamento (stripping).

Devido ao fato das partículas de cal possuírem tamanhos reduzidos (frequentemente $50 \%$ menor do que $5 \mu$ ) se comparadas a outros fíleres, esta leva 
vantagem em relação ao uso, pois resulta em maiores concentrações da substância no filme asfáltico, contribuindo significativamente para o enrijecimento do mástique. A rigidez do mástique exerce influência na resistência à fadiga em temperaturas intermediárias, na resistência à deformação permanente em altas temperaturas e na resistência ao trincamento em baixas temperaturas (BERGER et al., 2006; BARDINI et al., 2010 ).

Furlan (2006) constatou que a substituição de 1\% do filer natural por cal hidratada (tipo $\mathrm{CH} 1$ ) não imprimiu mudanças significativas nas propriedades originais (resistência e rigidez) das misturas asfálticas. Porém, quando em condições de parcial saturação, ficou evidente a melhoria na retenção de propriedades, mesmo após ciclos de condicionamentos térmicos, sobretudo em misturas constituídas de agregados graníticos.

Berger e Huege (2006), avaliando o módulo dinâmico $\left(\mathrm{E}^{*}\right)$ de misturas asfálticas, encontraram que a cal hidratada demonstra ser superior em relação a fíleres inertes em misturas asfálticas em condições de temperaturas elevadas. Esses pesquisadores afirmam ainda que a cal hidratada fortalecerá a mistura asfáltica o suficiente para resistir às deformações permanentes, principalmente nos primeiros anos de vida de serviço de um pavimento.

Quanto ao modo de aplicação, existem várias técnicas de incorporação da cal à mistura asfáltica. Os tipos mais usuais são a adição "a seco" e "diretamente ao asfalto". No método "a seco" a cal é misturada ao agregado e posteriormente o asfalto é misturado aos agregados. Já no outro método a cal é adicionada diretamente no ligante asfáltico e somente após este passo o asfalto é misturado aos agregados. A cal pode ser adicionada ao agregado tanto úmido quanto seco, pois quando adicionada ao agregado com superfície úmida, a porcentagem em massa pode aumentar de dois a três por cento em relação a mistura de cal com agregado de superfície seca. E esta umidade ioniza o agregado e ajuda a distribuir a cal na superfície do agregado (LITTLE e EPPS, 2001).

A cal viva $(\mathrm{CaO})$ não deve ser adicionada diretamente à mistura asfáltica, porque em contato com a água durante a vida de serviço, pode reagir e dar origem a $\mathrm{Ca}(\mathrm{OH})_{2}$. Esta reação expansiva pode criar uma variação de volume na mistura asfáltica, prejudicando o seu desempenho e reduzindo sua resistência (LITTLE e EPPS, 2001). 
Em suma a incorporação de cal nas misturas asfálticas é benéfica, pois reduz os efeitos deletérios da umidade no pavimento asfáltico, proporciona um bom desempenho em altas temperaturas, aumentando a resistência à deformação permanente, e aumentando o ciclo de vida do pavimento. Sebaaly (2006) afirmou que a cal aumenta em cerca de $40 \%$ a vida útil do pavimento. Porém, devido ao enrijecimento do mástique asfáltico, a taxa de relaxação das tensões diminui, o que em baixas temperaturas pode favorecer o desenvolvimento de rupturas de origem térmica e de trincas por fadiga.

\subsection{COMPACTAÇÃO E COMPACTIBILIDADE DE MISTURAS ASFÁLTICAS}

A compactação é um processo mecânico de aplicação de forças que tem a finalidade de reduzir o volume do material e por consequência promover maior densificação. Para Micaelo (2008) esta etapa construtiva é crucial para o futuro desempenho do pavimento. E é por meio deste processo que a mistura asfáltica passa do estado solto para o denso, pois partículas antes distantes umas das outras passam a ter contato entre si, como ilustrado nas figuras 3 e 4 .

$\mathrm{Na}$ compactação, além do fator temperatura, três variáveis compõem este processo e são ferramentas importantes de interpretação do teste: tensão aplicada, densidade e volume de vazios. Por meio da leitura de ensaio e obtendo estes parâmetros pode-se entender o comportamento/resposta do material durante $\mathrm{o}$ processo de compactação.

Segundo o Asphalt Institute (1989), a compactação é importante devido a três fatores:

1. Com o aumento do contato entre agregados ocorre maior atrito interno e por consequência resulta em uma mistura de maior estabilidade;

2. A redução do volume de vazios $(\mathrm{Vv})$, reduz a penetração da água e do ar, tornando a mistura mais resistente ao envelhecimento por oxidação e promove maior proteção da base;

3. Uma vez pouco compactado, o revestimento asfáltico apresentará maior volume de vazios, e desta forma ocorrerá pós-compactação pelo tráfego, que se apresentará nas trilhas de roda resultando em deformação permanente. 


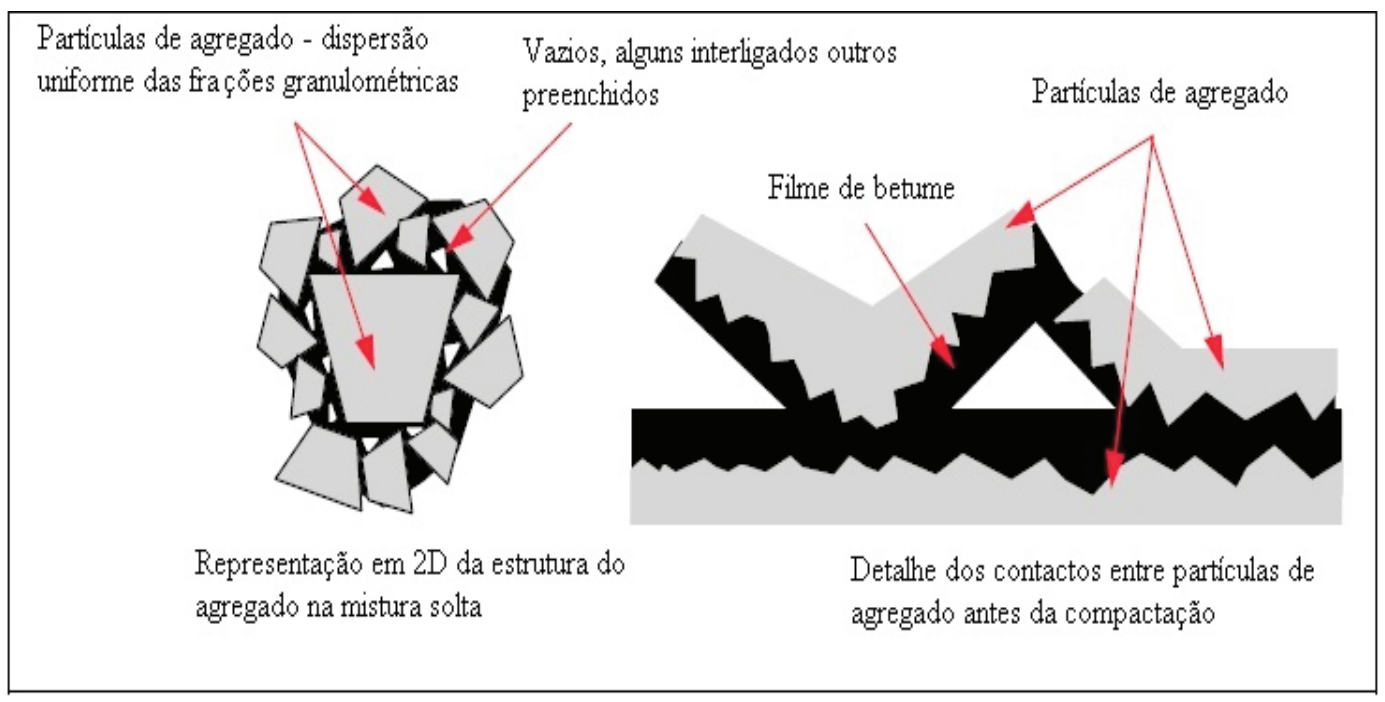

Figura 3 - Esquema da estrutura da mistura asfáltica antes da compactação final (Adaptado de Micaelo, 2008).

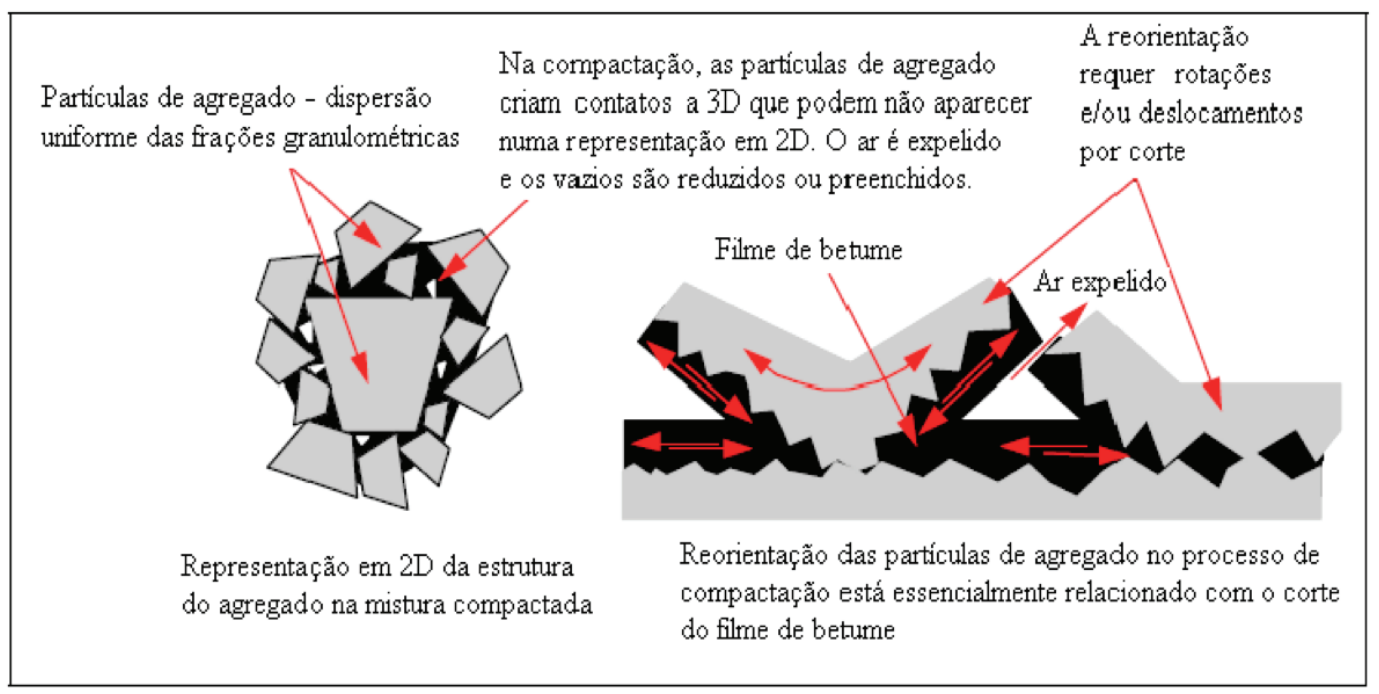

Figura 4 - Esquema da estrutura da mistura asfáltica após a compactação final (Adaptado de Micaelo, 2008).

Para Roberts et al. (1996 ), em campo, uma gama de variáveis influencia a eficiência da compactação de misturas asfálticas, como: temperatura do ar, umidade ambiente, espessura da camada asfáltica e temperatura da mistura asfáltica no momento da compactação.

A resistência à compactação é um efeito combinado entre agregado e asfalto, assim sendo a temperatura é muito importante neste processo. $\mathrm{O}$ asfalto tende a ser mais viscoso em temperaturas mais baixas e mais fluido em altas temperaturas. Logo, se a mistura estiver em temperaturas mais baixas que a indicada para o 
processo oferecerá maior resistência à compactação. Por outro lado temperaturas mais altas que as de compactação podem produzir sobrecompactação.

Mahmoud e Bahia (2004), afirmam que o teor de asfalto maior que o de projeto pode levar a problemas como redução do volume de vazios causando uma possível instabilidade da mistura asfáltica. Por outro lado, o conteúdo de asfalto abaixo do teor ótimo irá comprometer a durabilidade da mistura asfáltica.

Sob o esforço de compactação, a mistura asfáltica se densifica, expulsando o ar. Nesta etapa construtiva, os vazios entre as partículas são reduzidos e a área de contato entre elas aumenta. A modificação do volume de vazios nas misturas asfáltica é importante, pois aumenta a sua impermeabilidade, promove maior atrito interno entre os agregados, além de evitar a possibilidade de pós-compactação pelas cargas de tráfego.

Para Anderson et al. (2002), uma mistura asfáltica bem projetada, ou seja, com bom arranjo pétreo e adequado teor de asfalto, pode compactar a $4 \%$ de volume de vazios no final do processo de compactação, enquanto uma mistura asfáltica com arranjo pétreo inadequado e/ou elevado teor de asfalto pode compactar a $2 \%$ de volume de vazios para a mesma energia de compactação.

Uma gama de literaturas abordam a questão do intervalo de volume de vazios ideal no final da compactação e na pós-compactação pelo tráfego. Na metodologia Superpave $^{\circledR}$, é recomendada a obtenção de $4 \%$ de volume de vazios no número de giro de projeto $\left(\mathrm{N}_{\text {proj }}\right)$. A AASHTO (2007) orienta que os corpos de prova de misturas asfálticas devam ter volume de vazios entre 6 e $8 \%$, tanto pelo método de compactação Marshall quanto pelo método Superpave ${ }^{\circledR}$.

Em sua pesquisa, Roberts et al. (1996), cita que a mistura asfáltica deve ter o percentual de volume de vazios entre $6 \%$ e $8 \%$ logo após a construção e de $4 \%$ após 2 ou 3 anos de tráfego. Moura (2010) afirma que para as regiões tropicais, é recomendável que o volume de vazios final, ou seja, resultante da pós-compactação pela ação do tráfego, seja preferencialmente superior a $3 \%$.

\subsection{COMPACTAÇÃO GIRATÓRIA EM MISTURAS ASFÁLTICAS}

O período da II Guerra Mundial marcou um rápido crescimento de uso de materiais de asfalto e em paralelo surgiram também projetos para as misturas 
asfálticas. Em nível local foram adotados os métodos de dosagem Triaxial Smith, Hubbard Field e compactador giratório do Texas, sendo que os métodos Marshall e Hveem prevaleciam em relação aos demais procedimentos. Dos métodos citados cada um possuía o seu próprio método de compactação de suas amostras (HARMAN et al., 2002).

Em 1939, o Departamento de Transportes do Texas deu início aos estudos sobre o desempenho e controle das misturas asfálticas a fim de obter em laboratório a degradação do agregado, as densidades e os volumes de vazios de valor próximo aos encontrados em campo. E assim Philippi, Raines e Love desenvolveram a prensa giratória (Figura 5), uma unidade manual que foi usada de forma experimental e teve o seu uso padronizado somente em 1946.

O procedimento de compactação das amostras na prensa giratória do Texas se dava na seguinte forma (HUBBER, 1996; HARMAN et al., 2002):

i. Colocar o material a ser ensaiado em um molde de aço de diâmetro interno igual à 101,6 mm, sob um ângulo de 6 graus;

ii. Aplicar pressão próxima a $345 \mathrm{kPa}$;

iii. Girar manualmente o molde três vezes por meio de alavancas;

iv. Reajustar a pressão;

v. Girar novamente o molde três vezes por meio de alavancas até atingir a pressão de $1034 \mathrm{kPa}$;

vi. Aplicar uma carga adicional de $17 \mathrm{MPa}$ para finalizar a compactação.

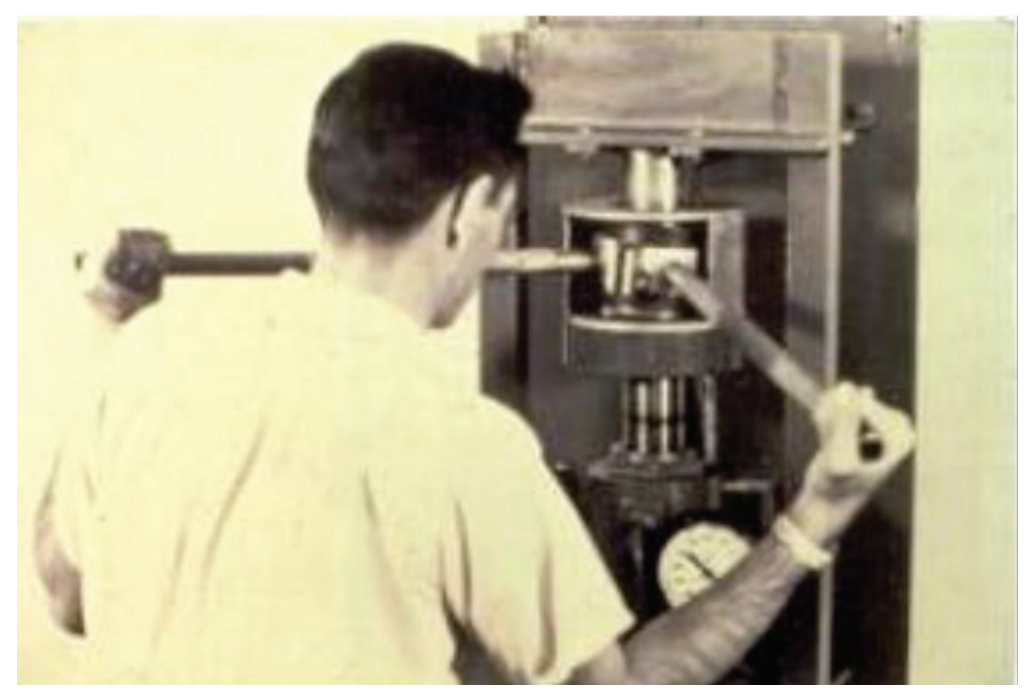

Figura 5 - Prensa giratória do Texas (Harman et al., 2002). 
Nos moldes de compactação do Departamento de Transportes do Texas, foi desenvolvido na década de 1950, por John L. McRae, o compactador giratório do Corpo de Engenheiros dos EUA. Este mecanismo de compactação mostrou que o impacto provocado pelo soquete do método Marshall não era adequado para simular as densidades nas trilhas de roda das pistas de pouso de aviões. Além disso, observou-se que os corpos de prova Marshall não reproduziam as propriedades volumétricas encontradas nos pavimentos em campo.

No compactador desenvolvido por McRae, o ângulo de giro era obtido por dois pontos, fazendo com que o mesmo oscilasse durante a compactação. Os parâmetros altura da amostra, pressão aplicada e ângulo de giro eram armazenados no equipamento e incorporados ao procedimento do método. Em 1993, o compactador giratório de McRae foi denominado de máquina de teste giratório (Gyratory Test Machine - GTM) (HARMAN et al., 2002).

Outros dispositivos de compactação giratória nos moldes da prensa giratória foram desenvolvidos. E como uma forma de harmonizar as especificações de compactação a Comunidade Européia de Asfalto adotou os conceitos de compactação de laboratório e projeto idealizados por Moultier (1977) e Bunnot (1986) do Laboratoire des Ponts et Chausées (LCPC) da França. O equipamento de compactação giratória do LCPC possuía tensão normal constante de $600 \mathrm{kPa}$ e ângulo de giro fixo de 1 grau (HARMAN et al., 2002; MARQUES, 2004).

Para sintetizar as evoluções que o compactador giratório passou ao longo de sua trajetória desde a sua concepção no ano de 1939, é apresentada na Tabela 2 a linha do tempo do seu progresso e as principais agências responsáveis pelo desenvolvimento deste equipamento. 
Tabela 2 - Histórico da evolução dos compactadores giratórios (Adaptado de Harman et al., 2002).

\begin{tabular}{|c|c|c|c|}
\hline Ano & Agência & Dimensões do CP & Características \\
\hline 1939 & DOT do Texas & $\begin{array}{l}\text { D: } 101,6 \mathrm{~mm} \\
\mathrm{H}: 50,8 \mathrm{~mm}\end{array}$ & $\begin{array}{l}\text { P: desconhecida } \\
\text { A: manual } \\
\text { F: Manual }\end{array}$ \\
\hline 1946 & $\begin{array}{l}\text { DOT do Texas } \\
\text { (norma do procedimento) }\end{array}$ & $\begin{aligned} \text { D: } 101,6 \text { e } 152,46 \mathrm{~mm} \\
\text { H: } 50,8 \text { e } 76,2 \mathrm{~mm}\end{aligned}$ & $\begin{array}{l}\text { P: variável } \\
\text { A: Fixado em } 6^{\circ} \\
\text { F: } 60 \mathrm{rpm}\end{array}$ \\
\hline 1957 & GTM / USACE & $\begin{array}{l}\text { D: } 152,4 \mathrm{~mm} \\
\text { H: variável }\end{array}$ & $\begin{array}{l}\text { P: variável } \\
\text { A: oscilando de } 0 \text { a } 3^{\circ} \\
\text { F: variando de } 12 \text { a } 18 \mathrm{rpm}\end{array}$ \\
\hline 1960’s & $\begin{array}{l}1^{\circ} \text { Protótipo francês LCPC } \\
\text { (com base no equipamento } \\
\text { texano) }\end{array}$ & $\begin{array}{l}\text { D: desconhecido } \\
\text { H:desconhecida }\end{array}$ & $\begin{array}{l}P \text { : variável } \\
\text { A: variável } \\
F \text { : variável }\end{array}$ \\
\hline 1968 & $2^{\circ}$ Protótipo Francês LCPC & $\begin{array}{l}\text { D: } 80 \text { ou } 120 \mathrm{~mm} \\
\text { H: variável }\end{array}$ & $\begin{array}{l}\text { P: Variável } \\
\text { A: Oscila de } 0,5 \text { a } 5^{\circ} \\
\text { F: Variável } \\
\text { M: Molde aquecido }\end{array}$ \\
\hline $\begin{array}{c}1974- \\
1985\end{array}$ & PCG1 e PCG2 - LCPC, & $\begin{array}{c}\text { D: } 160 \mathrm{~mm} \\
\mathrm{H}: 80 \text { e } 300 \mathrm{~mm}\end{array}$ & $\begin{array}{l}\text { P: } 600 \mathrm{kPa} \\
\text { A: Fixado de } 1 \text { a } 4^{\circ} \\
\text { F: Fixado de } 6 \mathrm{rpm} \text { a } 30 \mathrm{rpm}\end{array}$ \\
\hline 1991 & $\begin{array}{l}\text { Equipamento de ensaio de } \\
\text { cisalhamento giratório } \\
\text { modificado / FHWA }\end{array}$ & $\begin{array}{l}\text { D: } 152,4 \mathrm{~mm} \\
\mathrm{H}: 95,3 \mathrm{~mm}\end{array}$ & $\begin{array}{l}\text { P: } 600 \mathrm{kPa} \\
\text { A: Fixada de } 0,5 \text { a } 3^{\circ} \\
\text { F: } 30 \mathrm{rpm}\end{array}$ \\
\hline 1991 & DOT Texas - SHRP & $\begin{array}{c}\text { D: } 152,4 \mathrm{~mm} \\
\text { H: } 95,3 \mathrm{~mm}\end{array}$ & $\begin{array}{l}\mathrm{P}: 600 \mathrm{kPa} \\
\mathrm{F}: \text { variável }\end{array}$ \\
\hline 1993 & $\begin{array}{l}\text { Compactador Giratório } \\
\text { Superpave, SHRP }\end{array}$ & $\begin{array}{l}\text { D: } 150 \mathrm{~mm} \\
\mathrm{H}: 115 \mathrm{~mm}\end{array}$ & $\begin{array}{l}\text { P: } 600 \mathrm{kPa} \\
\text { A: Fixado em 1,25 } \\
\text { F: } 30 \mathrm{rpm}\end{array}$ \\
\hline 1996 & PCG3 - LCPC & $\begin{array}{l}\text { D: } 150 \mathrm{~mm} \\
\mathrm{H}: 100 \text { e } 160 \mathrm{~mm}\end{array}$ & $\begin{array}{l}\text { P: Fixada de } 500 \text { a } 800 \mathrm{kPa} \\
\text { A: Fixada de } 0,5 \text { a } 2^{\circ} \\
\text { F: Fixado de } 6 \text { a } 30 \mathrm{rpm}\end{array}$ \\
\hline
\end{tabular}

\subsection{COMPACTADOR GIRATÓRIO SUPERPAVE (CGS)}

No ano de 1987, foi estabelecido um plano de estudo do Strategic Highway Research Program (SHRP), conhecido por Superior Performing Asphalt Pavement, com o objetivo de melhorar o desempenho e a durabilidade das rodovias, através de modelos de previsão em laboratório mais próximos do que acontece in situ. Com o intuito de determinar qual dispositivo de compactação simularia de forma mais adequada a compactação de campo, foram estudados os compactadores: giratório 
Texas, por rolagem Exxon, soquete Marshall e amassamento linear Elf. Dentre os compactadores testados, o equipamento giratório Texas foi selecionado como o mais indicado para análises de misturas asfálticas.

A evolução das pesquisas originou adaptações no dispositivo de compactação e, principalmente, novas especificações de procedimentos laboratoriais e de caracterização de ligantes asfálticos, agregados e misturas asfálticas (MARQUES, 2004; BERNUCCl et al., 2007).

Uma das principais inovações do método de dosagem de misturas asfálticas Superpave ${ }^{\circledR}$ foi a incorporação da compactação por amassamento, que é realizada pelo Compactador Giratório Superpave ${ }^{\circledR}$ (CGS). O CGS surgiu de uma modificação do compactador giratório do Texas que, por sua vez, seguem os princípios da prensa francesa de cisalhamento giratório (PCG do LCPC). É dotado de estrutura de reação com uma base rotativa, medidor de altura, sistema de registro de dados e carregamento, cabeça de carga, medidor de pressão, molde e placa de base, conforme ilustra a Figura 6 (MOTTA et al., 1996).

Os parâmetros para a realização do ensaio de compactação fixados pelo Superpave ${ }^{\circledR}$, ilustrados na Figura 6, são:

i. Compressão vertical de $600 \mathrm{kPa}$;

ii. Ângulo de giro igual a $1,25^{\circ} \pm 0,02$;

iii. Frequência de 30 giros por minuto;

iv. Número de giros, característico de cada mistura asfáltica e é em função do tráfego a ser simulado.

Para se chegar nestes parâmetros de ensaio, foram construídos projetos pilotos, a partir de resultados com diferentes tipos de misturas asfálticas. Originalmente, o ângulo de giro fixado em $1^{\circ}$ mostrou alguns problemas ao longo dos estudos, pois era insuficiente para alcançar o percentual de vazios de ar de projeto de $4 \%$ ao se usar o número de giros de projeto $\left(\mathrm{N}_{\text {proj }}\right)$ de 113. O ângulo de giro foi aumentado para $1,27^{\circ}$ e os projetos das misturas foram refeitos. Através, destes estudos verificou-se a melhor adequação do ângulo de $1,27^{\circ}$, porque além de ser atingido volume de vazios de $4 \%$, foi observada alguma redução no teor de asfalto de projeto. 


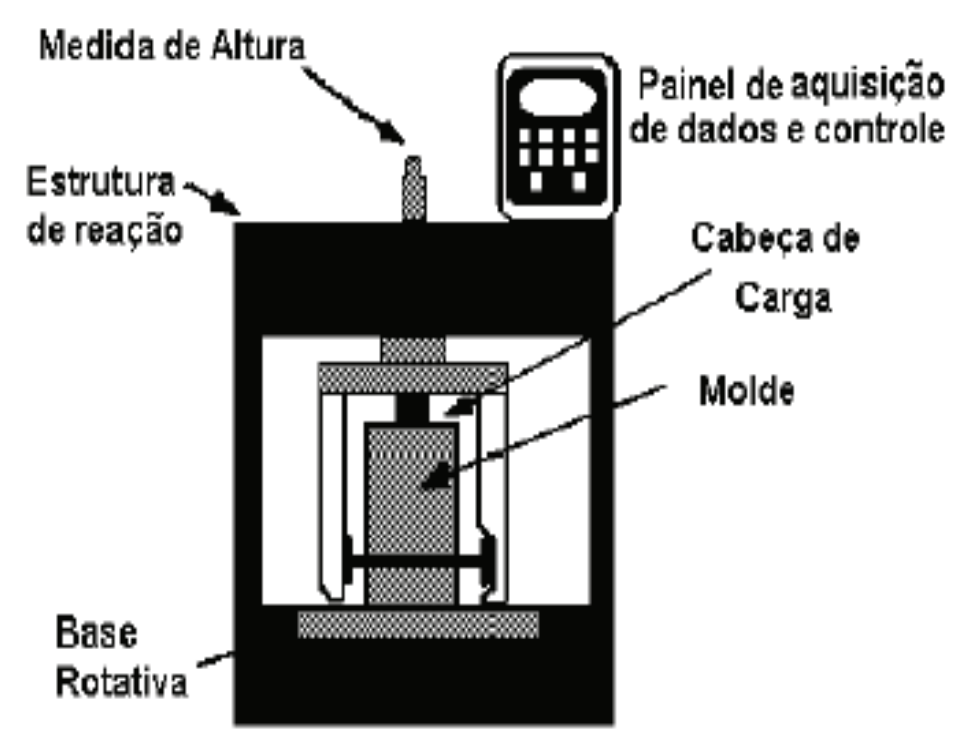

Figura 6 - Esquema do CGS (Motta et al., 1996).

Mais tarde a frequência de giros fixada em 30 giros por minuto, desde os primeiros experimentos com a compactação giratória do Texas, foi adotada como padrão, pois ficou comprovado que este parâmetro tem pouca influência na taxa de densificação, além de mostrar resultados confiáveis, praticados durante um período de tempo considerável. A tensão normal adotada de $600 \mathrm{kPa}$, foi a mesma utilizada no método francês do LCPC, e estudos concluíram que este parâmetro pouco influenciava a compactação (MARQUES, 2004).

Uma das vantagens da compactação pelo CGS é a possibilidade de acompanhamento das alturas dos corpos de prova durante o processo de compactação, para cada número de giro. O registro destas alturas é importante, uma vez que é possível observar a forma como se desenvolve a compactação do material e também estimar a habilidade de densificação da mistura asfáltica. Desta forma, o compactador Superpave ${ }^{\circledR}$, além de promover a compactação das misturas asfálticas permite a obtenção da curva de densificação do material, que é obtida pela relação entre número de giros com a densidade máxima teórica da mistura (Gmm), como ilustrado na Figura 7. Ao observar como se comporta a curva de densificação, pode-se interpretar e entender a resposta do material aos esforços de compactação. 


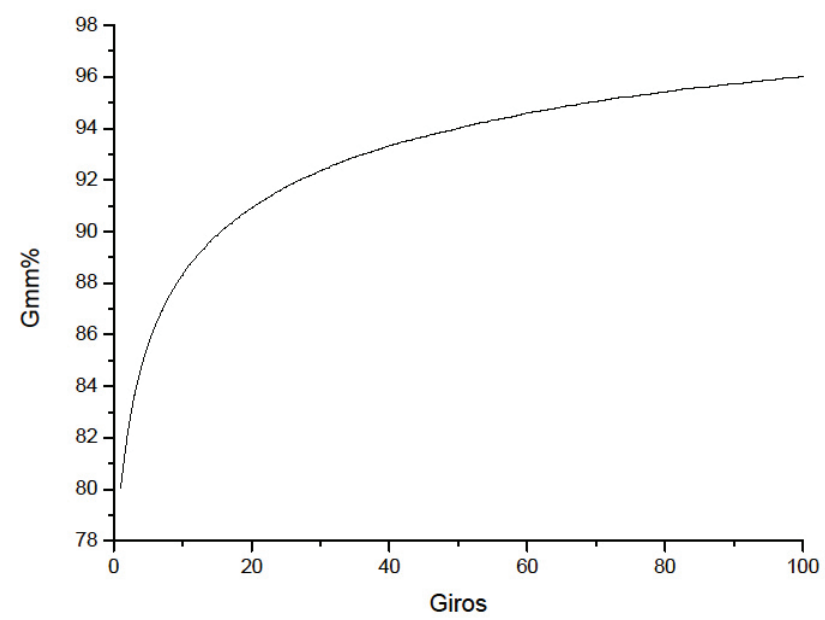

Figura 7 - Curva de densificação obtida na compactação giratória Superpave®.

\subsection{PARÂMENTROS ORIUNDOS DA COMPACTAÇÃO}

Por se tratar de uma tecnologia relativamente nova, a metodologia Superpave $^{\circledR}$ tem sido uma área motivadora de grandes discussões entre pesquisadores da pavimentação asfáltica. Alguns estudos têm sido realizados voltados para as propriedades mecânicas, uma vez que em algumas fases de projeto esta metodologia baseia-se somente nas propriedades volumétricas.

No que se refere à previsão do desempenho do pavimento em serviço, acredita-se que o método seja ainda insuficiente, pois é entendido que são as propriedades mecânicas que se relacionam diretamente com o desempenho do pavimento. No entanto, inserir novos procedimentos ao método Superpave ${ }^{\circledR}$ implicaria em novos custos, além de requerer uma grande mobilização para se dar treinamento antes de operacionalizar um outro processo. Nesta ótica, já que o uso do CGS atualmente é bastante difundido, é mais desejável o utilizar para obtenção de parâmetros mecânicos das misturas asfálticas, fazendo-se uso de novas interpretações dos dados obtidos na compactação (NASCIMENTO, 2008).

Neste contexto Bahia et al.(1998), apontaram que os dados da compactação no CGS poderiam estar sendo subutilizados e introduziram a noção de dividir a curva de densificação em duas secções, uma representando compactação na fase da construção e a outra representando a densificação pelo tráfego. A partir deste estudo, foram propostos índices que se originaram de interpretações da curva 
gerada na compactação: Construction Densification Index (CDI) e Traffic Densification Index (TDI).

Mais adiante, com os avanços das pesquisas nesta área, Delage (2000) propôs outros novos índices de energia: Compaction Force Index (CFI) e Traffic Force Index (TFI). Estes índices derivam da medição da resistência ao cisalhamento de misturas asfálticas. Além destes parâmetros citados foi indicado por Dessouky et al. (2004) o uso do índice Contact Energy Índex (CEI) como ferramenta de avaliação da estrutura dos agregados de uma mistura asfáltica. Outro índice proposto por diversos autores foi o Locking Point (LP), de forma a se evitar a compactação em excesso.

\subsubsection{Construction Densification Index (CDI) e Traffic Densification Index (TDI)}

Os índices oriundos da curva de densificação propostos por Bahia et al. (1998) podem ser ferramentas capazes de mensurar e dar indícios da trabalhabilidade e da resistência à deformação permanente das misturas asfálticas ao longo da construção do pavimento e da vida de serviço. A variável de densificação $C D I$, ilustrada na Figura 8, é determinada pela área sob a curva de compactação a partir do $N_{\text {inicial }}$ até o valor de $92 \%$ de $G_{m m}$ (densidade máxima teórica) da mistura. O CDI é um parâmetro da curva de densificação capaz de mensurar a energia $e$, por consequência, o trabalho requerido durante a compactação, para que se atinja a densidade exigida na mistura durante a construção da via.

O índice de energia TDI, ilustrado na Figura 9, é determinado pela área sob a curva de compactação entre os valores de 92 e $98 \%$ do valor da densidade máxima teórica $(\mathrm{Gmm})$. É uma variável utilizada para mensurar o processo de densificação decorrente das cargas de tráfego e Mahmoud e Bahia (2004) afirmam que correlaciona fortemente com a resistência da mistura asfáltica à deformação permanente. 


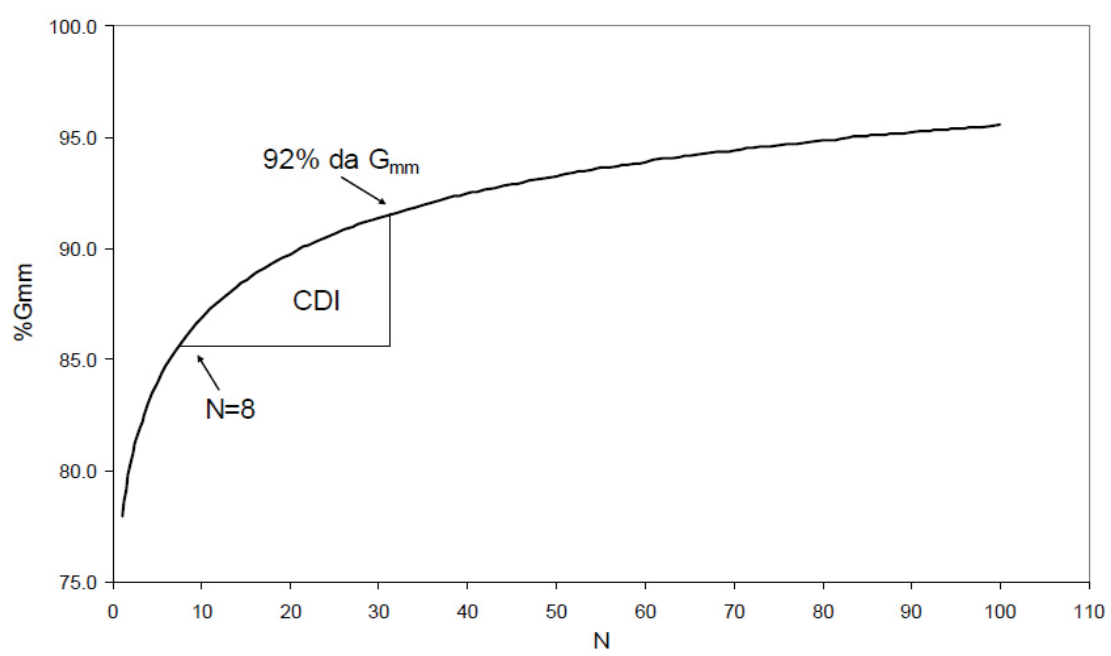

Figura 8- Representação gráfica do índice CDI (Nascimento, 2008).

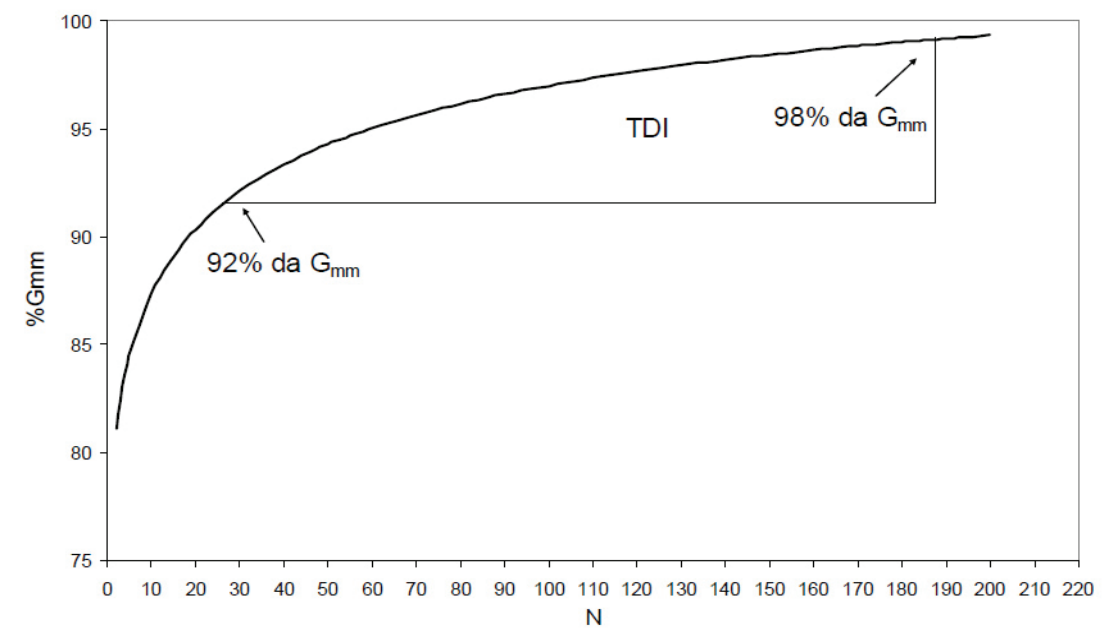

Figura 9 - Representação gráfica do índice TDI (Nascimento, 2008).

Nascimento (2008), em sua pesquisa, propôs o uso do parâmetro TDI ${ }_{m}$ (que deriva do TDI) que se considera a área a partir de $92 \%$ até o $\mathrm{N}$ de projeto $\left(\mathrm{N}_{\text {proj }}\right)$. Este índice possibilita o aproveitamento dos corpos de prova moldados até o número de giros de projeto $\left(\mathrm{N}_{\text {proj }}\right)$. Com essa adaptação, pode-se avaliar corpos de prova de misturas asfálticas que não atingiram $98 \%$ de $\mathrm{Gmm}$.

No que se refere ao comportamento típico desses parâmetros, são desejáveis valores baixos de CDI e valores elevados de TDI, indicando que a mistura asfáltica necessita de pouca energia para a densificação e que possui certa resistência à densificação pelas cargas de tráfego ao longo da vida de serviço. Cada tipo de mistura asfáltica apresenta valores particulares e concentrados em determinados intervalos em função do tipo de granulometria, do tamanho máximo nominal dos 
agregados, do tipo de ligante asfáltico, entre outros. No entanto, valores muito baixos de CDI, apesar de indicarem uma facilidade de execução da compactação no momento da construção podem indicar também uma baixa angularidade e textura lisa dos agregados usados na mistura asfáltica, o que é um fator desfavorável em relação à resistência à deformação permanente (MAHBOUD e BAHIA, 2004; NASCIMENTO, 2008; ONOFRE, 2012).

Mahmoud e Bahia (2004) estudaram o comportamento de 11 tipos de misturas asfálticas e concluiu que os índices de tráfego (TFI e TDI), medidos a partir do compactador giratório Superpave ${ }^{\circledR}$, correlacionam fortemente com a resistência da mistura à deformação permanente.

Nascimento (2008) avaliou oito tipos de misturas asfálticas, compactadas por impacto e por amassamento, variando o tamanho máximo nominal $(9,5 \mathrm{~mm}, 12,5 \mathrm{~mm}$, 19,0mm e $25 \mathrm{~mm}$ ) e ligantes asfálticos de origens diferentes (CAP 20 REVAP e REGAP). Neste estudo encontrou fortes correlações entre o TDI $\mathrm{m}_{\mathrm{m}}$ TDI e a deformação permanente. Para o autor estas são variáveis que podem ser utilizadas para estimar a resistência à deformação permanente de uma mistura asfáltica. $O$ autor concluiu também que, na dosagem de misturas asfálticas densas, para aplicação em rodovias brasileiras, há necessidade de se fixar os valores de CDI e TDI para o tráfego médio e pesado, para se garantir um bom desempenho referente à deformação permanente. Os valores recomendados neste trabalho estão apresentados na Tabela 3.

Tabela 3 - Valores de CDI e TDI sugeridos por Nascimento ( 2008) para rodovias brasileiras.

\begin{tabular}{|c|c|c|}
\hline Tráfego & CDI & TDI \\
\hline Médio & $>50$ & $>250$ \\
\hline Pesado & $>50$ & $>400$ \\
\hline
\end{tabular}

Lopes et al. (2011) avaliaram 3 tipos de misturas asfálticas de diferentes tamanhos máximos nominais $(9,5 \mathrm{~mm}, 12,5 \mathrm{~mm}$ e $19,0 \mathrm{~mm})$ quanto ao comportamento frente a compactação giratória, e compararam os índices de densificação (CDI e TDI ${ }_{m}$ ), com os resultados obtidos no ensaio de deformação permanente. Esses autores não verificaram fortes correlações entre os índices CDI, $\mathrm{TDI}_{\mathrm{m}}$ e deformação permanente, contudo indicaram como promissora a relação 
entre o TDIm e a inclinação da reta de deformação permanente e o valor de deformação final nos 30.000 ciclos do ensaio simulador de tráfego.

Onofre (2012) estudou 17 misturas, variando o tipo de agregado (de origem granítica e basáltica) e utilizando ligantes virgens, modificados por polímeros e por ácido polifosfórico. Essa caracterização teve o objetivo de avaliar a influência dos modificadores, principalmente do PPA, na resistência à deformação permanente de misturas. Apesar da tentativa de correlacionar parâmetros da curva de densificação (CDI e TDI ${ }_{m}$ ) com parâmetros dos ensaios de creep, esta pesquisa encontrou valores baixos de $\mathrm{R}^{2}$, ao relacionar $\mathrm{CDI}$ e $\mathrm{TDI}_{\mathrm{m}}$ com os resultados dos ensaios de deformação permanente.

\subsubsection{Locking Point}

O primeiro conceito de Locking point ou ponto de travamento dos agregados (PTA) foi proposto pelo Departamento do Estado de Illinois após 3 anos de observações e comparações entre curvas de densificação, de campo e laboratório. Este conceito foi concebido como uma alternativa para substituir o número de giros de projeto ( $\mathrm{N}_{\text {projeto }}$ ) e também como forma de evitar que a mistura fosse compactada em excesso. Locking point é definido como o número do giro em que o esqueleto dos agregados "trava" em conjunto resultando muito pouca compactação adicional, ou ainda, em alguma degradação dos agregados minerais. Esta degradação dos agregados pétreos pode resultar em misturas asfálticas mais vulneráveis à ação da água e a deformação permanente.

Prowell e Brown (2007) apresentam dois métodos para a determinação do número de giros que resulta no travamento dos agregados. O primeiro método foi proposto por Pine (1997) que definiu o LP como sendo o primeiro giro de um conjunto de três giros de mesma altura, precedido por um par de giros, também de mesma altura e $0,1 \mathrm{~mm}$ maiores que a sequência de 3 giros, como mostrado no esquema da Figura 10. 


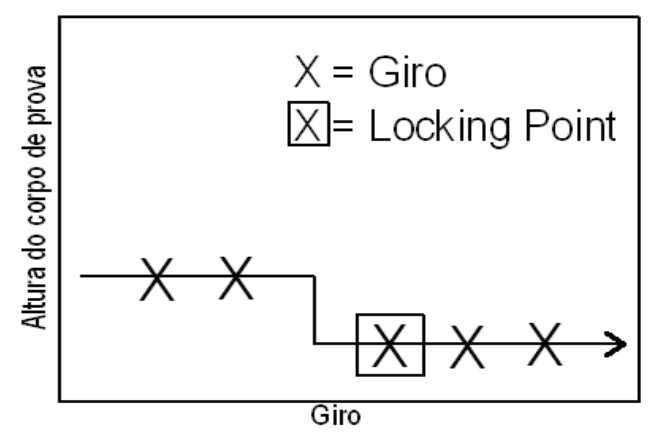

Figura 10 - Esquema 3-2 de Pine (1997) - (Adaptado de Prowell and Brown, 2007).

Posteriormente, Vavrik e Carpenter (1998) redefiniram o ponto de travamento dos agregados, que o definiu como sendo o primeiro giro de uma seqüência de 3 giros de mesma altura, precedido por 2 pares de giros de mesma altura, sendo o primeiro par $0,1 \mathrm{~mm}$ maior do que o PTA e o segundo $0,1 \mathrm{~mm}$ maior do que o primeiro par. As Figuras 10 e 11, mostram graficamente os esquemas para encontrar o número de giro referente ao PTA.

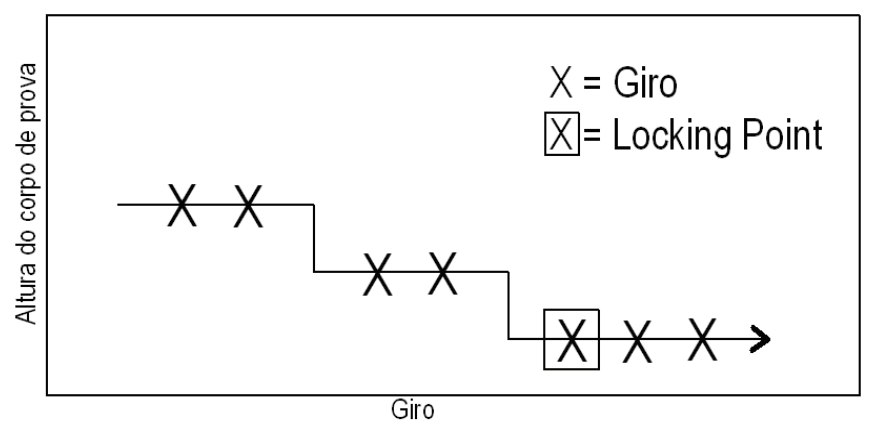

Figura 11 - Esquema 3-2-2 de Vavrik e Carpenter (1998) - (Adaptado de Prowell and Brown, 2007).

A Tabela 4 apresenta um exemplo de como se obter o número de giros que determina o locking point. Este exemplo se baseia nos dados de um corpo de prova desta pesquisa. No exemplo dado, o LP corresponde ao numero de giro 54 a uma altura de $68,9 \mathrm{~mm}$, tanto pelo método 3-2-2 quanto pelo método 3-2,.

Em sua pesquisa, Dantas (2012) adotou o conceito de LP de Vavrik e Carpenter (1998) e observou o aumento da tensão de compressão leva a uma redução do número de giros para se alcançar o ponto de travamento dos agregados.

Nascimento (2008) encontrou forte correlação $\left(R^{2}=0,93\right)$ entre os parâmetros CDI e LP (VAVRIK E CARPENTER, 1998) para misturas asfálticas dosadas pelo 
método Superpave ${ }^{\circledR}$. Para esse pesquisador os dois índices estão coerentes com aquilo que se propõem a medir: o travamento do esqueleto pétreo durante a compactação.

Tabela 4 - Alturas do corpo de prova no compactador giratório para determinação do LP 33-3 ou3-2.

\begin{tabular}{|c|c|c|c|c|c|}
\hline Giros & $\begin{array}{c}\text { Altura } \\
(\mathrm{mm})\end{array}$ & Giros & $\begin{array}{c}\text { Altura } \\
(\mathrm{mm})\end{array}$ & Giros & $\begin{array}{c}\text { Altura } \\
(\mathrm{mm})\end{array}$ \\
\hline 1 & 81,4 & 21 & 71,3 & 41 & 69,6 \\
\hline 2 & 79,2 & 22 & 71,2 & 42 & 69,5 \\
\hline 3 & 77,8 & 23 & 71,0 & 43 & 69,5 \\
\hline 4 & 76,8 & 24 & 70,9 & 44 & 69,4 \\
\hline 5 & 76,0 & 25 & 70,8 & 45 & 69,4 \\
\hline 6 & 75,3 & 26 & 70,7 & 46 & 69,3 \\
\hline 7 & 74,7 & 27 & 70,6 & 47 & 69,3 \\
\hline 8 & 74,3 & 28 & 70,5 & 48 & 69,2 \\
\hline 9 & 73,9 & 29 & 70,4 & 49 & 69,2 \\
\hline 10 & 73,5 & 30 & 70,3 & 50 & 69,1 \\
\hline 11 & 73,2 & 31 & 70,2 & 51 & 69,1 \\
\hline 12 & 72,9 & 32 & 70,2 & 52 & 69,0 \\
\hline 13 & 72,7 & 33 & 70,1 & 53 & 69,0 \\
\hline 14 & 72,5 & 34 & 70,0 & 54 & 68,9 \\
\hline 15 & 72,3 & 35 & 69,9 & 55 & 68,9 \\
\hline 16 & 72,1 & 36 & 69,9 & 56 & 68,9 \\
\hline 17 & 71,9 & 37 & 69,8 & 57 & 68,9 \\
\hline 18 & 71,7 & 38 & 69,7 & 58 & 68,9 \\
\hline 19 & 71,6 & 39 & 69,7 & 59 & 68,9 \\
\hline 20 & 71,4 & 40 & 69,6 & 60 & 68,8 \\
\hline
\end{tabular}

Leiva-Villacorta (2007) também estudou o conceito de locking point e observou que misturas asfálticas de gradações finas alcançaram o ponto de travamento com menor número de giros que as de gradações intermediárias e grossas. Segundo as análises feitas ao longo do estudo, o LP pode ser usado para representar a aplicação da energia necessária para alcançar um nível de compactação e resistência à deformação permanente de uma mistura asfáltica.

\subsection{ENSAIOS DE PREVISÃO DE DEFORMAÇÃO PERMANENTE}

Alguns dos ensaios em laboratório mais utilizados para previsão de desempenho de misturas asfálticas quanto à deformação permanente são: fluência por compressão uniaxial estática e dinâmica, ensaio triaxial com carregamento repetido e simulador de tráfego. Estes ensaios são ferramentas de previsão das propriedades mecânicas de misturas asfálticas. 
Para avaliar o comportamento da mistura nos ensaios laboratoriais, é importante utilizar temperaturas que representem as condições a que a mistura estará sujeita in situ. Como a deformação permanente ocorre essencialmente e de forma mais acelerada em temperaturas mais elevadas, por vezes próximas às de serviço de algumas regiões, as temperaturas de ensaio devem representar estas condições (GARDETE, 2006).

\subsubsection{Creep estático}

$\mathrm{Na}$ década de 1970, os resultados de pesquisas da Companhia Shell sinalizaram que devido à viscoelasticidade das misturas asfálticas, ou seja, por possuírem uma parcela que se deforma ao longo do tempo e outra parcela instantânea, seria adequado analisar a função fluência pela relação tensão versus deformação. Desde então, o ensaio proposto de compressão uniaxial estática tem sido uma importante ferramenta de avaliação de propriedades das misturas asfálticas quanto à deformação permanente.

O creep estático consiste na aplicação de carga constante sobre um corpo de prova, em temperatura e intervalo de tempo padronizados. Mede-se neste ensaio a relação existente entre o deslocamento axial total do corpo de prova e o tempo de carregamento, como mostra o esquema da Figura 12. Do processo de carregamento e descarregamento do corpo de prova são extraídas informações para determinar as componentes elásticas (recuperáveis) e as plásticas (não recuperam ao longo do tempo). Os parâmetros obtidos no ensaio são:

- Deformação total (Dt);

- Deformação não-recuperável ou deformação viscoplástica $\left(\varepsilon_{\mathrm{vp}}\right)$;

- Deformação recuperável ou deformação elástica $\left(\varepsilon_{1 t}\right)$;

- Recuperação elástica;

- Módulo de fluência;

- Inclinação da curva de fluência. 




Figura 12 - Curva de creep estático (Moura, 2010).

A deformação total no corpo de prova é obtida ao final do ensaio. A deformação viscoplástica ou permanente é a que permanece mesmo após o período de tempo de recuperação. A deformação elástica é calculada pela diferença entre a deformação total e a deformação viscoplástica. A recuperação elástica é dada pela relação em porcentagem entre a deformação recuperável e a deformação total.

O módulo de fluência pode ser determinado considerando o período de ensaio de fluência (carregamento) ou no período total do ensaio que engloba a recuperação. O módulo de fluência é expresso pela relação entre a tensão aplicada e a deformação específica sofrida pelo corpo de prova; está indiretamente relacionado com a rigidez da mistura asfáltica e pode caracterizar misturas asfálticas quanto à resistência à deformação permanente (SANTANNA-GRECO, 2004; MUGAYAR, 2004).

Traçando-se uma curva da deformação versus tempo de carregamento de um corpo de prova levado até a ruptura, Figura 13, é possível observar três estágios da curva de fluência de uma mistura asfáltica:

- Zona Primária: região da curva em que a taxa de deformação é elevada, pois ocorrem grandes deformações em um curto período de carregamento;

- Zona Secundária: região da curva em que a taxa de aumento de deformação é constante, neste trecho há uma diminuição da inclinação;

- Zona Terciária: região da curva em que a taxa de deformação volta a crescer até chegar à ruptura do corpo de prova. O tempo de carregamento em que inicia este estágio denomina-se tempo de fluência ou flow time (FT). 


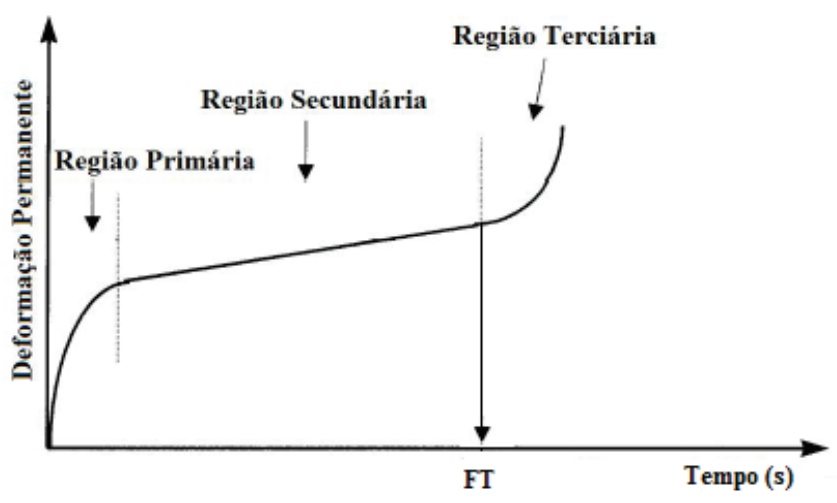

Figura 13 - Curva de fluência de uma mistura asfáltica.

Atualmente, o tempo de fluência tem sido considerado um importante parâmetro para a avaliação da deformação permanente em misturas asfálticas e representa momento onde se inicia uma maior velocidade de deformação da mistura asfáltica (CAVALCANTI, 2010). Witczak et al. (2002), estudando a deformação permanente em campo e em laboratório, encontrou boas relações entre e o flow time e os afundamentos medidos em três tipos de pistas experimentais. No estudo realizado por Santanna-Greco (2004), foi observado que no ensaio de fluência por compressão uniaxial estática a variação do tipo de ligante não teve influência nos valores obtidos. Quando adicionados os polímeros SBS, SBR, EVA e BRP ao asfalto, o creep estático não foi capaz de distinguir mudança no comportamento das misturas quanto à deformação permanente e, desta forma, o aumento da capacidade de recuperação elástica não foi detectado.

Para Mugayar (2004), o ensaio fluência por compressão estática foi capaz de distinguir as diferenças de comportamento entre misturas asfálticas de diferentes distribuições granulométricas. No entanto, não foi capaz de distinguir o efeito da adição de modificadores ao ligante asfáltico. Nesse sentido, Valkering et al.,(1990), explicou que o ensaio uniaxial de carga repetida, creep dinâmico, é mais indicado para aquilatar o efeito do ligante modificado no comportamento dos carregamentos em misturas asfálticas. Esses pesquisadores atribuíram essa aptidão do ensaio de creep dinâmico à configuração carga-descarga, cujos intervalos permitem evidenciar o comportamento da mistura quanto à recuperação da deformação elástica à deformação. 


\subsubsection{Creep Dinâmico}

O ensaio uniaxial de carga repetida ou creep dinâmico, foi proposto em 1983 por Finn (FINN et al., 1983). Neste ensaio, aplicam-se pulsos de carga no corpo de prova, em um determinado intervalo de tempo, frequência, intervalo de carregamento e temperatura. Os resultados são apresentados em termos da deformação permanente acumulada versus número de ciclos de carga, conforme é feito também para o Creep estático. E a curva de fluência pode ser dividida em três zonas: primária, secundária e terciária. Porém, o número de ciclo em que inicia o estágio terciário (cisalhamento constante), é denominado Flow Number (FN), Figura 14.

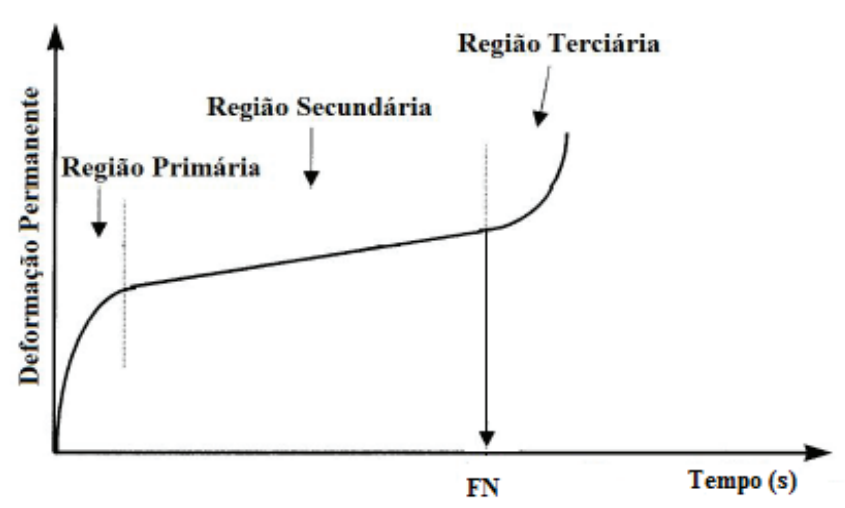

Figura 14 - Curva de fluência de uma mistura asfáltica.

Witczak et al. (2002), correlacionou o FN com a deformação permanente e obteve um alto valor de $\mathrm{R}^{2}$, como ilustra o Figura 15 . Foi observado também neste estudo que alguns parâmetros dos ensaios de creep tiveram boas relações com a profundidade dos afundamentos das trilhas de rodas, entre eles estão: i) Inclinação da curva de deformação; ii) Parcela de deformação permanente; iii) Razão entre a parcela de deformação total versus de deformação elástica. No entanto, no ranking de classificação o flow number foi o parâmetro que melhor se relacionou com a DP. 




Figura 15 - Relação entre Flow Number versus afundamento de trilha de roda das pistas de Minnesota (Witczak et al., 2002).

Para os ensaios de Creep estático e dinâmico não há um consenso a respeito do uso de uma tensão de carregamento e atualmente os ensaios de creep podem ser executados em três condições de tensão:

i) Tensão de 0,1 MPa: representa a tensão em que as deformações se dão no intervalo de viscosidade linear (Método Shell, Van de Loo, 1974);

ii) Tensão de 0,4 MPa: representa um nível de tensão média encontrada no centro da camada asfáltica em condições de serviço (Little et al., 1993);

iii) Tensão de 0,7 $\mathrm{MPa}$, representa o valor que simula a pressão de enchimento dos pneus de veículos comerciais e condições mais próximas de serviço (Mohamed e Yue,1994).

Mugayar (2004) apresentou um resumo de especificações citadas por vários autores que destaca a falta de padronização dos tempos de carregamento e repouso, tensão de carregamento, altura do corpo de prova e temperatura, apresentado na Tabela 5.

Nascimento (2008) encontrou boa correlação entre os ensaios de deformação permanente no simulador de tráfego francês e flow number, determinado no ensaio uniaxial de carga repetida, e ambos foram sensíveis às variações do esqueleto pétreo. Este estudo verificou também boas correlações entre os resultados destes ensaios e o CDI; que foram ainda melhores com o TDI. 
Tabela 5 - Especificações de tempos de carregamento e repouso, tensão de carregamento, altura do corpo de prova e temperatura (Adaptada de Mugayar, 2004).

\begin{tabular}{|c|c|c|c|c|c|}
\hline Pesquisador (es) & Ano & $\begin{array}{l}\text { Tempo de } \\
\text { carga (s) }\end{array}$ & $\begin{array}{l}\text { Tempo de } \\
\text { repouso (s) }\end{array}$ & $\begin{array}{c}\text { Tensão de } \\
\text { carregamento (Kpa) }\end{array}$ & $\begin{array}{l}\text { Temperatura } \\
\text { de ensaio }\left(C^{\circ}\right)\end{array}$ \\
\hline Majidzadeh e Khedr & 1979 & 0,125 & 0,375 & $206,7-402,4$ & $27-38-49$ \\
\hline Valkering et al. & 1990 & 0,2 & 1,8 & 100 & $40-50$ \\
\hline Srivastava & 1992 & 0,9 & 5,4 & - & 40 \\
\hline Hanson et al. & 1994 & 0,1 & 0,9 & $827^{* *}$ & ** \\
\hline Mohamed e Yue & 1994 & 0,2 & 1,8 & 690 & $25-40$ \\
\hline Corté et al. & 1994 & 0,2 & 1,8 & 100 & 40 \\
\hline Sousa et al. & 1995 & 0,1 & 0,6 & 69 & 60 \\
\hline Sá e Motta & 1995 & 0,1 & 0,9 & $100-400$ & $25-45$ \\
\hline Ulmgren & 1997 & 1 & 1 & 100 & $* * *$ \\
\hline Qi e Witczak & 1998 & 0,1 & 0,1 & 138 & 38 \\
\hline Taira e Fabbri & 1999 & 0,2 & 1,8 & 100 & 40 \\
\hline
\end{tabular}

*Utilização da prensa eletro-hidráulica - ** Pressão de confinamento de $138 \mathrm{KPa}$ - *** Temperatura não especificada. 
CAPÍTULO 3

3. MATERIAIS

\subsection{CONSIDERAÇÕES INICIAIS}

Neste capítulo são apresentados os materiais utilizados neste trabalho e suas características, assim como os procedimentos empregados nos ensaios laboratoriais.

\subsection{AGREGADOS}

Os agregados minerais utilizados neste estudo têm origem granítica e são provenientes da Pedreira São Jerônimo, situada em Valinhos-SP. A Figura 16 apresenta a curva granulométrica adotada neste trabalho, que foi o centro da Faixa "C" (DNIT ES 031/2004).

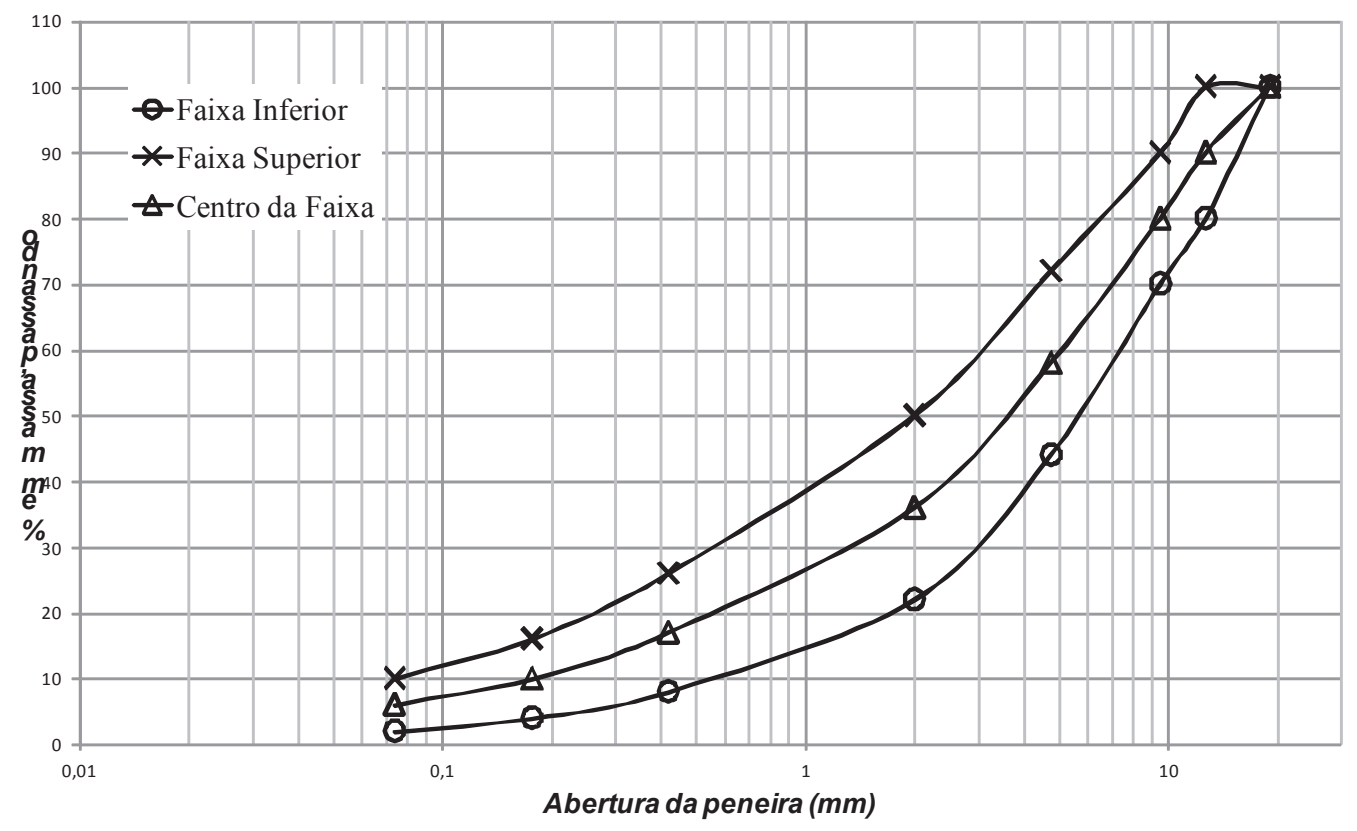

Figura 16 - Faixa C do DNIT, limites superior, inferior e centro de faixa.

Após o recebimento do material, foi procedido o enquadramento do agregado utilizado na mistura, foram realizados também ensaios de caracterização dos agregados. Realizaram-se os ensaios de Abrasão Los Angeles (DNER - ME 35/98), adesividade do ligante asfáltico no agregado graúdo (DNER - ME 078/94) e 
agregado miúdo (DNER - ME 079/94), densidade aparente e real dos agregados grossos e finos seguindo as normas ASTM C- 27-01 e ASTM C-128-01. Na Tabela 6 , consta um resumo dos ensaios de caracterização do agregado mineral.

Tabela 6 - Quadro resumo dos ensaios de caracterização dos agregados.

\begin{tabular}{llc}
\hline \multicolumn{1}{c}{ Propriedades } & Normas & Agregado \\
\hline Adesividade (Rielder Weber) & DNER-ME 078/94 & Má \\
Adesividade (RLL Modificado) & DNER-ME 079/94 & Não Satisfatória \\
Abrasão Los Angeles & DNER - ME 35/98 & $23 \%$ \\
Densidade Real & ASTM C-128-01 & 2,608 \\
Densidade Aparente & ASTM C-127-01 & 2,593 \\
\hline
\end{tabular}

\subsection{LIGANTE ASFÁLTICO}

Neste estudo, foram empregados dois tipos de ligantes asfálticos, fornecidos pela Betunel Indústria e Comércio Ltda de Ribeirão Preto-SP: CAP 50/70 convencional e CAP 50/70 modificado pelo polímero SBS de nome comercial Stylink ${ }^{\circledR}$ (este ligante é classificado pelo grau de desempenho PG 76-22).

Para se estimar as temperaturas de usinagem $\left(T_{U}\right)$ e compactação $\left(T_{C}\right)$, realizaram-se os ensaios de viscosidade Brookfield, de acordo com o que preconiza a norma ASTM D4402-02. Após a execução deste ensaio, foi possível traçar a curva de viscosidade versus temperatura, como ilustrado na Figura 17. Analisando este gráfico, fica evidente o efeito da temperatura nos ligantes asfálticos. Para mesmos valores de temperaturas de usinagem, o asfalto modificado pelo polímero SBS $\left(\right.$ Stylink $^{\circledR}$ ) apresentou viscosidades maiores em relação ao CAP 50-70. Deste modo, pode-se dizer que o Stylink PG 76-22 é mais consistente que o CAP 50-70 a altas temperaturas. 


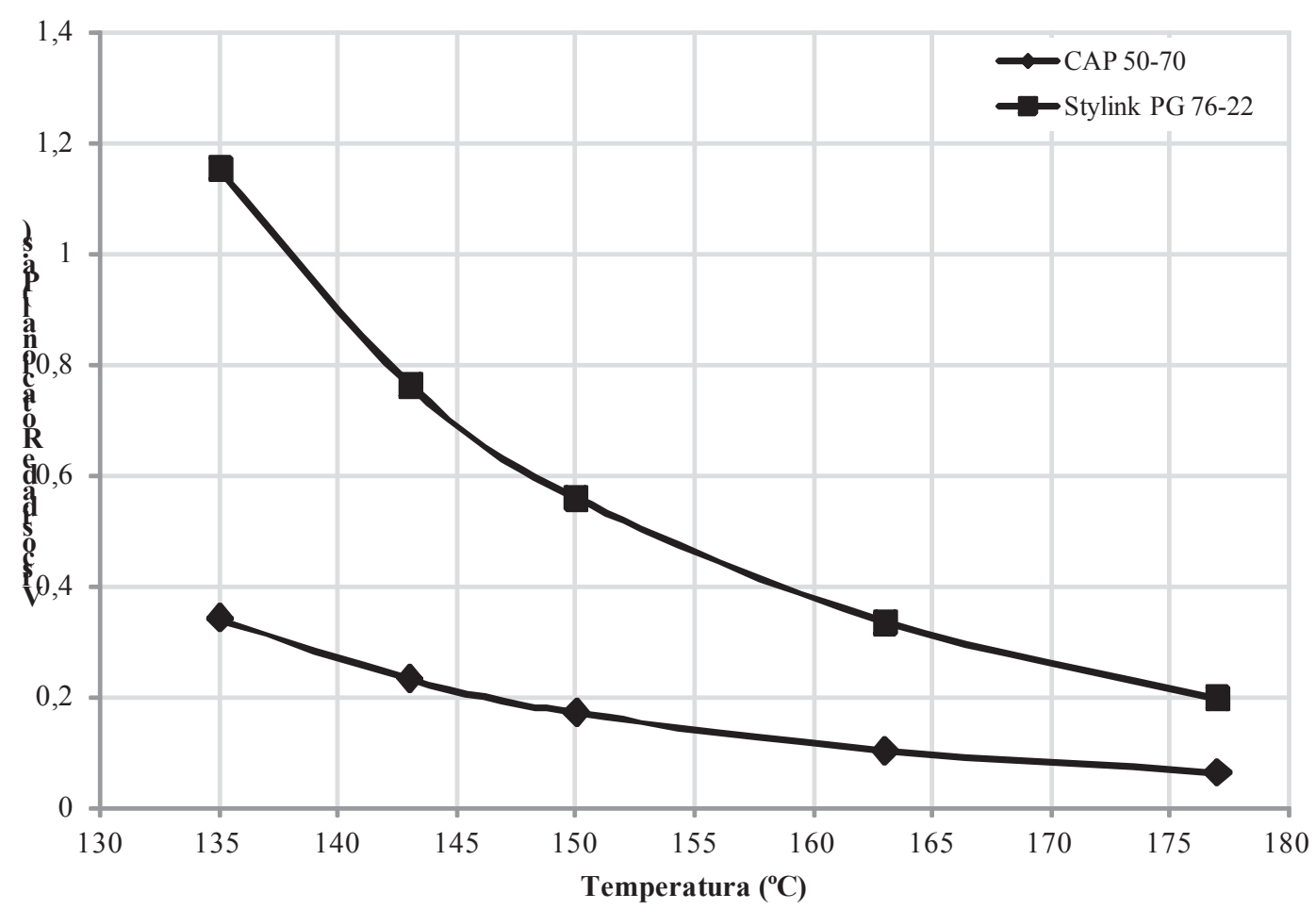

Figura 17 - Curva da viscosidade versus temperatura dos ligantes asfálticos estudados.

Os valores encontrados para as temperaturas de usinagem e compactação são apresentados na Tabela 7. Na prática estabeleceu-se que para cada ligante asfáltico estudado fosse adotada uma temperatura média do intervalo obtido. Para o ligante asfáltico convencional chegou-se ao valor de $150^{\circ} \mathrm{C}$ para temperatura de operação na usinagem e $140^{\circ} \mathrm{C}$ para a compactação. Enquanto para o ligante asfáltico modificado, a temperatura de usinagem ficou em $180^{\circ} \mathrm{C}$ e a temperatura de compactação em $168^{\circ} \mathrm{C}$.

Tabela 7 - Valores obtidos de temperatura de usinagem e compactação.

\begin{tabular}{lll}
\hline & CAP 50/70 & CAP 50/70 + SBS \\
\hline Compactação & $137^{\circ} \mathrm{C}$ a $142^{\circ} \mathrm{C}$ & $165^{\circ} \mathrm{C}$ a $171^{\circ} \mathrm{C}$ \\
Usinagem & $147^{\circ} \mathrm{C}$ a $153^{\circ} \mathrm{C}$ & $178^{\circ} \mathrm{C}$ a $182^{\circ} \mathrm{C}$ \\
\hline
\end{tabular}




\subsection{CAL HIDRATADA}

Foi adicionada ao agregado de algumas misturas asfálticas deste estudo, cerca de 18 gramas de cal hidrata cálcica tipo $\mathrm{CH} 1$ (Supercal ${ }^{\circledR}$ ), que corresponde à $1,5 \%$ da fração de agregado (1200 g). 
CAPITULO 4

4. MÉTODO

\subsection{CONSIDERAÇÕES INICIAIS}

Neste capítulo é descrita a metodologia de avaliação da compactação giratória e dos ensaios de previsão de deformação permanente. Os ensaios deste estudo foram desenvolvidos no Departamento de Transportes da Escola de Engenharia de São Carlos. E sua realização foi em paralelo com outra pesquisa de mestrado da aluna Andressa Ka Yan Ng, que estuda as propriedades mecânicas das misturas asfálticas.

Com o objetivo de observar os efeitos de três fatores em diferentes níveis com relação ao desenvolvimento da deformação permanente, foi desenvolvido o seguinte programa experimental:

- Fator 1 - Tipo de asfalto (2 níveis): CAP 50/70 e CAP 50/70 modificado por polímero;

- Fator 2 - Volume de vazios (2 níveis): 4 e 7\%;

- Fator 3 - Aditivo (2 níveis): Com cal e sem cal;

O programa experimental possui configuração $2 \times 2 \times 2$ e resulta em oito condições experimentais (CE). Dois outros elementos foram considerados no experimento: temperatura e tipo de carregamento. Esses dois elementos considerados foram: (i) temperatura, variando em 2 níveis, $40^{\circ} \mathrm{C}$ e $50^{\circ} \mathrm{C}$ e (ii) tipo de carregamento, variando em dois níveis, estático e dinâmico. Ressalta-se que esse dois elementos não são considerados como fatores no programa experimental, mas se tratam de artifícios para conseguir obter evidências de comportamento.

No tratamento dos dados buscou-se entender os efeitos dos fatores experimentais, na tentativa de identificar a influência destes nos dados de compactação e deformação permanente.

Após a compreensão da intensidade dos efeitos (CAP, Vv, cal) sobre as propriedades avaliadas pelos ensaios mecânicos, foram selecionados alguns parâmetros identificados como importantes e relacionáveis entre si. 


\subsection{MISTURA ASFÁLTICA}

Neste estudo, a dosagem das misturas asfálticas não obedeceu integralmente a metodologia Superpave ${ }^{\circledR}$, uma vez que, na etapa de seleção da distribuição granulométrica, adotou-se a usualmente utilizada na região. E em seguida, para terse uma previsão do teor de asfalto necessário para total cobrimento dos agregados, determinou-se o teor de ligante inicial $\left(\mathrm{t}_{\mathrm{i}}\right)$ a partir do método da Superfície Específica (DNER M - 148 -60). O teor provável de ligante asfáltico foi de 5,0\% para o centro da Faixa C. Posteriormente, determinou-se o teor de projeto a partir da compactação de três corpos de prova com o teor de ligante inicial $\left(\mathrm{t}_{\mathrm{i}}\right)$ e outros três teores $\left( \pm 0,5\right.$ e $\mathrm{t}_{\mathrm{i}}$ $+1 \%$ ) em relação ao $\mathrm{t}_{\mathrm{i}}$. Deste modo, são três $\mathrm{CPs}$ para cada teor de asfalto estimado sendo que dois destes corpos de prova foram destinados para a dosagem e um para a determinação da densidade máxima teórica $(\mathrm{Gmm})$ a partir do ensaio Rice (ASTM D 2041-2000).

A compactação dos corpos de prova foi realizada pelo compactador giratório da marca australiana IPC, ilustrado pela Figura 18, sob tensão aplicada de $600 \mathrm{kPa}$, ângulo de giro de $1,25^{\circ}$ e velocidade de 300 RPM.

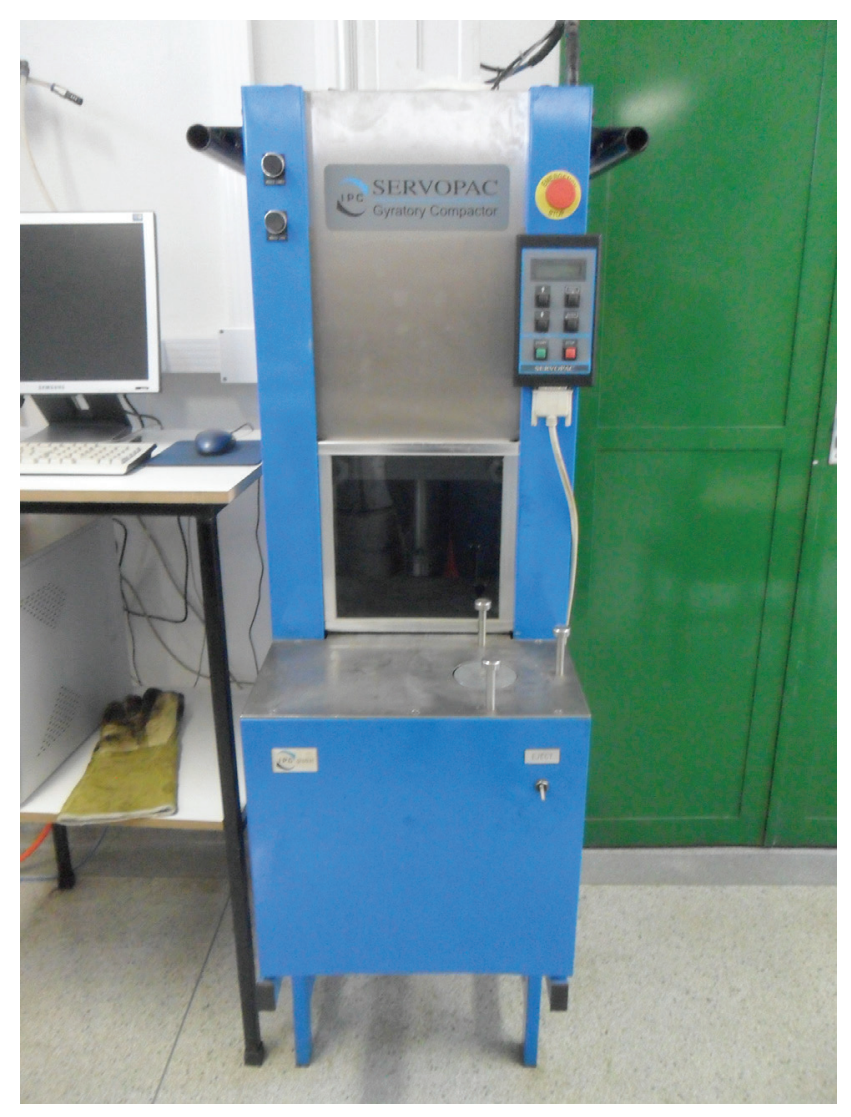

Figura 18 - Compactador Giratório Superpave ${ }^{\circledR}$ 
Para compactar as amostras, foi escolhido o nível de tráfego médio a alto. $\mathrm{E}$ de acordo com os procedimentos da metodologia adotada, para o tráfego adotado, a quantidade de ligante ideal deve corresponder à:

i) $\quad 4 \%$ de vazios para o número de giros de projeto igual a 100 ;

ii) Vazio do agregado mineral (VAM) maior que $13 \%$ para o tamanho máximo nominal (TMN) de 12,7 mm;

iii) $\quad 65 \%<$ RBV $<75 \%$;

iv) $\quad$ Gmm@Ninicial $<89 \%$;

v) Gmm@Nmáximo<98\%;

vi) Proporção de fíler/asfalto entre 0,6 e 1,8 (AASHTO M323, 2004).

O tráfego também define o número de giros, o $N_{\text {inicial }}, N_{\text {projeto }}$ e $N_{\text {máximo que }}$ para a situação adotada são 8, 100 e 160, respectivamente, como apresentado na Tabela 8. O Nprojeto é usado na seleção do teor de asfalto enquanto o $\mathrm{N}_{\text {inicial }}$ e $\mathrm{N}_{\text {máximo }}$ são usados na avaliação da compactabilidade da mistura asfáltica.

Tabela 8 - N de projeto segundo o tráfego a ser simulado.

\begin{tabular}{c|c|c|c|l}
\hline $\begin{array}{l}\text { ESALs } \\
\text { Projeto } \\
\text { (milhões) }\end{array}$ & \multicolumn{2}{|l|}{$\begin{array}{l}\text { Parâmetros de } \\
\text { Compactação }\end{array}$} & \multicolumn{2}{|c}{ Tráfego } \\
\cline { 2 - 4 } & Ninicial & Nprojeto & Nmáximo & \\
\hline$<0,3$ & 6 & 50 & 75 & $\begin{array}{l}\text { Tráfego muito leve (vias locais e } \\
\text { vias onde a circulação de } \\
\text { caminhões é proibida) }\end{array}$ \\
\hline 0,3 a $<3$ & 7 & 75 & 115 & Tráfego médio (vias coletoras) \\
\hline 3 a $<30$ & 8 & 100 & 160 & $\begin{array}{l}\text { Tráfego médio alto (vias } \\
\text { principais, algumas rodovias } \\
\text { interestaduais) }\end{array}$ \\
\hline$\geq 30$ & 9 & 125 & 205 & $\begin{array}{l}\text { Tráfego muito elevado (estação } \\
\text { de pesagem de caminhão, } \\
\text { rodovias interestaduais) }\end{array}$ \\
\hline
\end{tabular}


Finalizada a compactação do corpo de prova para os teores de asfalto inicial, é feita a determinação de volume de vazios $(\mathrm{Vv})$ da mistura compactada nos esforços $\mathrm{N}_{\text {projeto }}$ através da pesagem a seco, imersa e superficialmente seca (ASTM D 3203 - 94).

Para determinar-se finalmente o teor de ligante ideal, em gráfico traçou-se a curva de $\mathrm{V} v$ versus teor de ligante asfáltico inicial. De acordo com o método Superpave ${ }^{\circledR}$, o teor de ligante asfáltico ideal é aquele que a mistura asfáltica alcance $4 \%$ de volume de vazios para Nprojeto igual a 100 giros. Dada a condição, determinou-se que para misturas asfálticas com ligante convencional o teor de asfalto foi $4,25 \%$ e para as misturas com ligante modificado foi de $4,50 \%$.

No processo de moldagem dos corpos de prova, efetuou-se primeiramente o procedimento de estabilização da temperatura (2 horas na temperatura de compactação), segundo o que preconiza a norma AASHTO PP2. Posteriormente, deu-se início à etapa de compactação dos corpos de prova. Para moldar os corpos de prova de forma que alcançassem o percentual de vazios das condições experimentais, procedeu-se: (a) número de giros $=100$ para se alcançar $V v=4 \%$ e (b) número de giros $=40$ para se alcançar $V v=7 \%$.

\subsection{PROCESSAMENTO DA CURVA DE COMPACTAÇÃO - PARÂMETROS INCIDENTAIS}

Em um primeiro momento estimou-se para cada giro a massa específica aparente $\left(G_{m b}\right)$, que dá-se pela relação massa seca pelo seu respectivo volume. A seguir, multiplicou-se a massa específica aparente por um fator de correção (F.C), a fim de obter-se a massa específica aparente corrigida $\left(G_{m b}\right.$ corrigida). Este fator de correção é encontrado pela relação $G_{m b}$ medida pela $\mathrm{G}_{\mathrm{mb}}$ estimada, do último número de giro do corpo de prova. Logo após, para cada giro dividiu-se a $G_{m b}$ corrigida pela $G_{m m}$ e multiplicou-se pelo número total de giros, para se chegar ao percentual de densificação $\left(\mathrm{G}_{\mathrm{mm}} \%\right)$. Com os resultados processados, foi possível traçar as curvas de compactação, que relaciona o número de giros pelo percentual de $\mathrm{G}_{\mathrm{mm}}$.

Com os valores das alturas dos corpos de prova obtidos após a compactação por amassamento, foi possível calcular os parâmetros oriundos da curva de 
densificação: CDI, TDI $I_{m}$ e LP. Para o cálculo do CDI, indicado pela Equação 1, fezse o somatório das áreas do trapézio compreendidas abaixo da curva de compactação a partir do número de giro igual a oito $\left(\mathrm{N}_{8}\right)$ até o número de giro correspondente ao imediatamente menor ou igual a $92 \%$ da $\mathrm{G}_{\mathrm{mm}}$. Nesta pesquisa os corpos de prova não foram moldados até $98 \%$ da $\mathrm{Gmm}$ e por este motivo calculouse o $\mathrm{TDI}_{\mathrm{m}}$. Este parâmetro descrito pela Equação 2, foi obtido pelo somatório das áreas do trapézio a partir do número de giros correspondente a $92 \%$ da $G_{m m}$ até o ultimo giro. A Figura 19 ilustra o esquema gráfico para os parâmetros descritos.

$$
\begin{gathered}
\sum_{i=8}^{92 \%} A i \\
\sum_{i=92 \%}^{G m m-n^{\circ} \text { final }} A i
\end{gathered}
$$

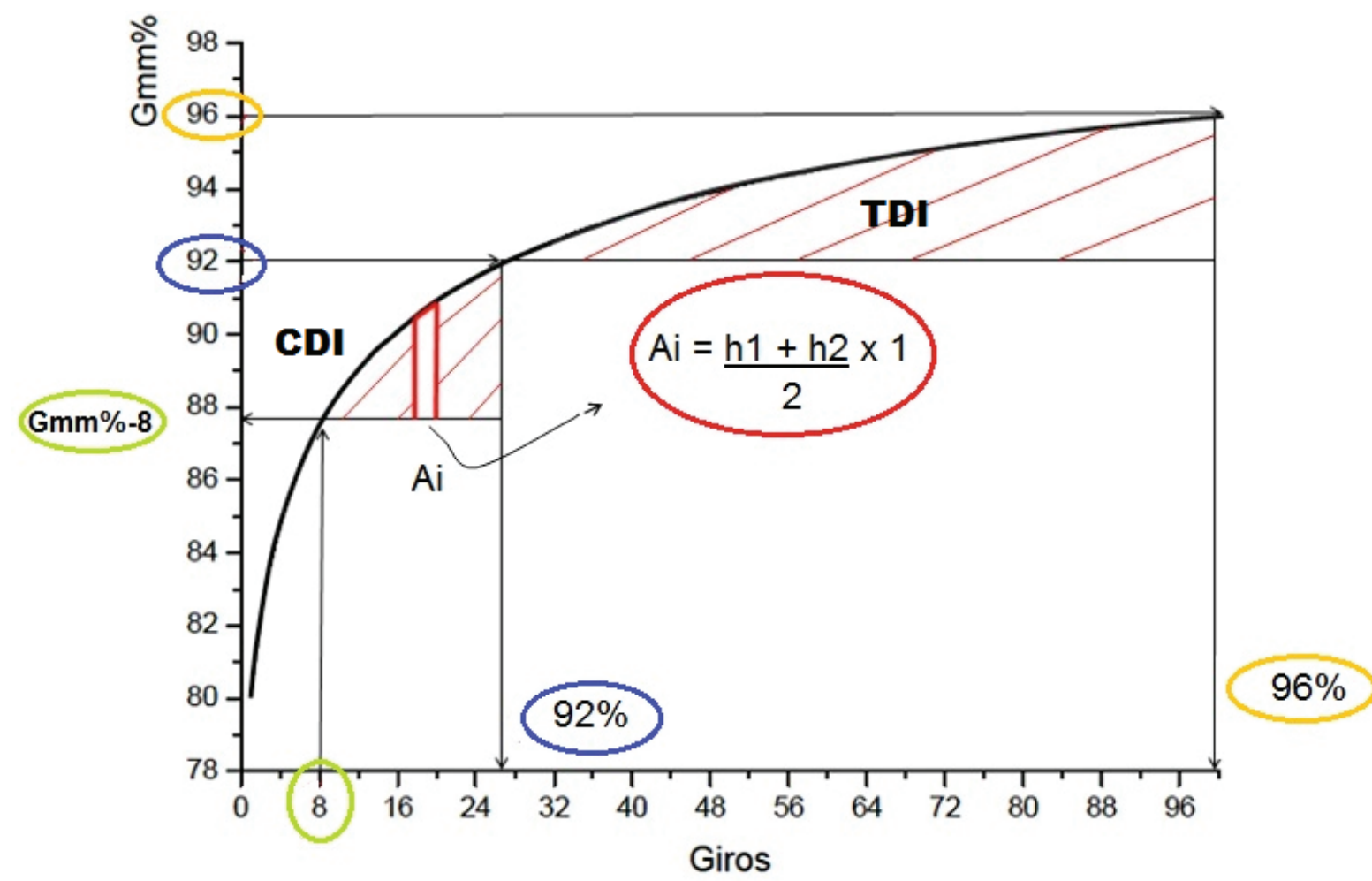

Figura 19 - Representação do cálculo dos parâmetros CDI e TDIm. 
O locking point foi calculado por dois processos, primeiramente pelo método de Pine (1997) e posteriormente pelo método de Vavrik e Carpenter (1998), métodos esses que já foram descritos no item 2.8.2, do capítulo 2. Estes conceitos foram adotados com o intuito de dar suporte na avaliação da estabilização dos corpos de prova na compactação. Com o auxílio da planilha eletrônica Excel foram compilados os dados de todos os CPs e com as ferramentas deste programa foram localizados estes índices.

\subsection{ENSAIOS MECÂNICOS}

Nesta pesquisa, os ensaios adotados para analisar as misturas asfálticas quanto à deformação permanente foram: fluência por compressão uniaxial estática e dinâmica. Os corpos de prova foram submetidos a ensaios em duas temperaturas: 40 e $50{ }^{\circ} \mathrm{C}$.

\subsubsection{Fluência por compressão uniaxial estática (creep estático)}

O ensaio de creep estático configura-se pela aplicação de uma carga estática e contínua de compressão sobre um corpo de prova, Figura 20. Em um primeiro momento, os corpos de prova passaram pela fase de pré-condicionamento, que consiste na aplicação de carga estática por cinco minutos, seguido por um intervalo de tempo para recuperação.

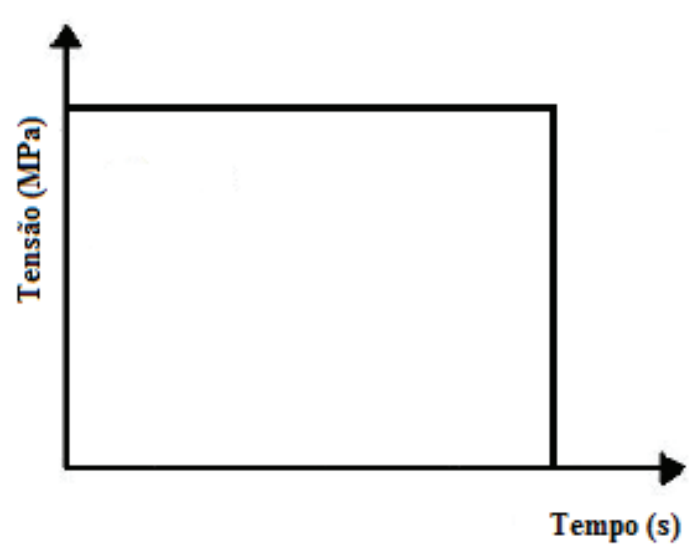

Figura 20 - Carregamento creep estático. 
Para atender às condições experimentais delimitadas por este estudo, o ensaio foi realizado com carregamento de 0,4 MPa (Little et al., 1993) em duas temperaturas: 40 e $50^{\circ} \mathrm{C}$. A carga estática foi aplicada durante sessenta minutos e 0 intervalo de recuperação foi de quinze minutos. Durante este período, foram realizadas medidas das deformações axiais por dois medidores do tipo linear variable differential transducer (LVDT). Os valores de deslocamento axial apresentados pelos corpos de prova em decorrência das solicitações da carga de ensaio foram determinados pela média aritmética das leituras dos dois LVDT's .

A deformação sofrida pelo corpo de prova em função do tempo de ensaio gera a curva de fluência do material e a partir desta relação é possível calcular os parâmetros para análise da mistura asfáltica, eles são:

a) Deformação total em 4500s (Equação 3);

b) Módulo de fluência em 3600s (Equação 4);

c) Inclinação do estágio secundário da curva de deformação versus tempo de carregamento ( Equação 5).

$$
\begin{gathered}
D_{t}=\frac{\Delta h_{4500}}{h_{0}} \\
M_{f}=\frac{\sigma}{D_{t}} \\
I_{\text {curva }}=\frac{\log \varepsilon_{8600}-\log \varepsilon_{1000}}{\log 3600-\log 1000}
\end{gathered}
$$

Onde:

$D_{t}=$ Deformação total $(\mathrm{mm} / \mathrm{mm})$;

$\Delta h_{4500}=$ Variação da altura do corpo de prova, após o período de recuperação (4500s);

$\Delta h_{0}=$ Medida inicial da altura do corpo de prova $(\mathrm{mm}) ;$

$M_{f}=$ Módulo de fluência para 3600 segundos de ensaio (MPa); 
$\sigma=$ Tensão de ensaio;

$\mathrm{I}_{\text {curva }}=$ Inclinação da curva de deformação;

$\varepsilon_{3600}-$ Deformação para 3600s de ensaio;

$\boldsymbol{\varepsilon}_{1000}-$ Deformação para 1000s de ensaio.

A aquisição dos dados de ensaio de creep estático foi realizada com o auxílio de uma ferramenta computacional desenvolvida em Labview $7.1^{\circledR}$, pelo Prof. Dr. Glauco Tulio Pessa Fabbri da Escola de Engenharia de São Carlos (Departamento de Transportes). Um exemplo de tela capturada deste software, é apresentada na Figura 21, onde se podem observar as curvas de fluências dos deslocamentos axiais obtidas pela leitura dos dois LVDT's e a curva de aplicação de carga ao longo do ensaio.

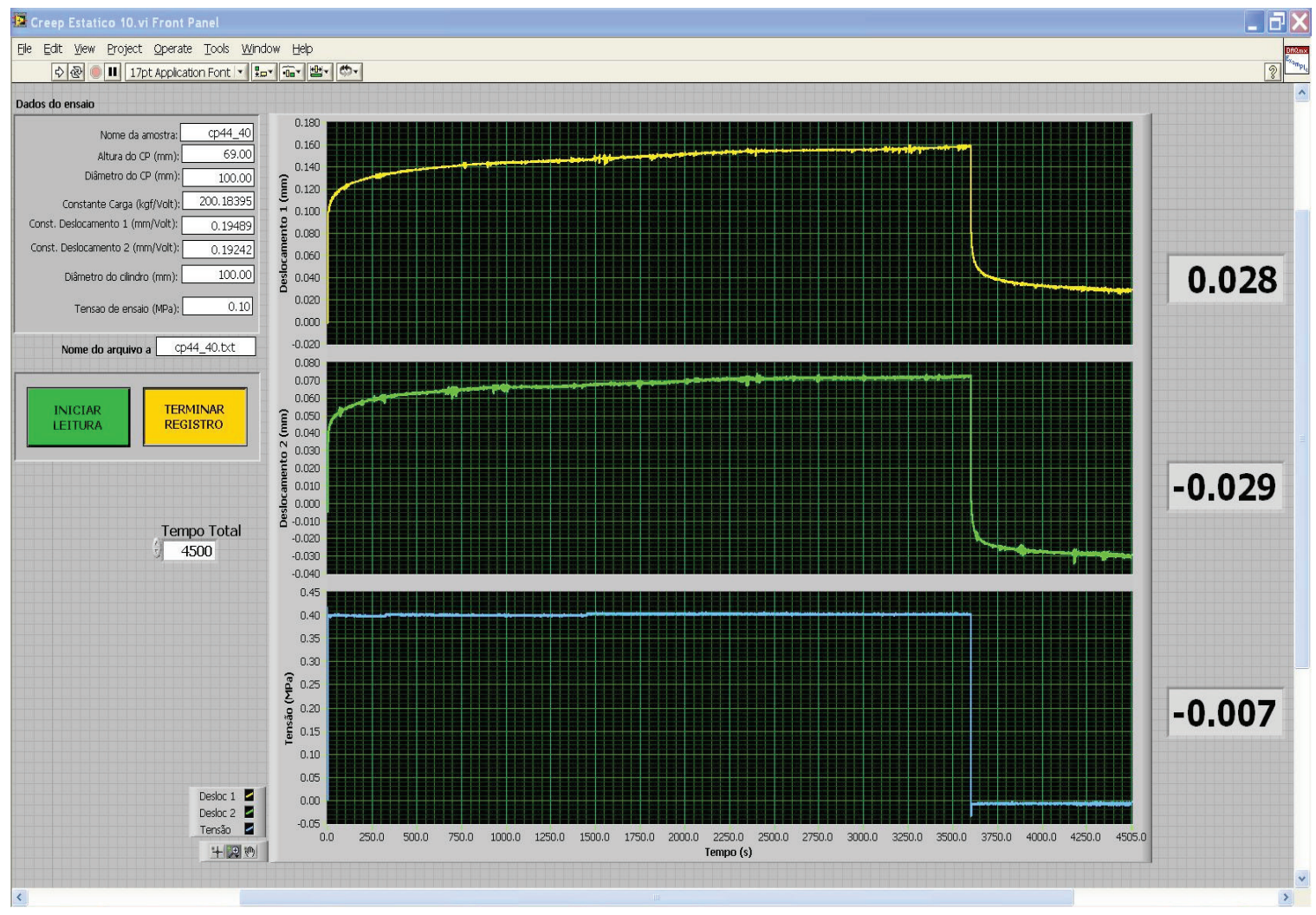

Figura 21 - Exemplo de tela do ensaio de Creep Estático em Labview 7.1®

Obtidos os parâmetros e as curvas de fluência do ensaio, foi possível dar-se início às análises das misturas asfálticas, considerando a influência das condições experimentais. 


\subsubsection{Fluência por compressão uniaxial dinâmica (creep dinâmico)}

O creep dinâmico foi realizado nas temperaturas de 40 e $50^{\circ} \mathrm{C}$ e o ensaio consistiu na aplicação de uma carga de compressão axial e cíclica de 0,4 MPa, sendo o tempo de carregamento de 0,1 segundo e oa recuperação de 0,9 segundos, a Figura 22 mostra um esquema da aplicação de carga do ensaio.

O ensaio teve duração de 3600 segundos, precedidos por um condicionamento que consistiu de 200 ciclos de carregamento. A carga aplicada e os deslocamentos axiais sofridos pelo corpo de prova foram medidos e registrados eletronicamente por dois pontos de leitura, os medidores tipo LVDT (linear variable differential transducers). O deslocamento sofrido pelo corpo de prova foi calculado pela média aritmética das leituras dos dois LVDT's.

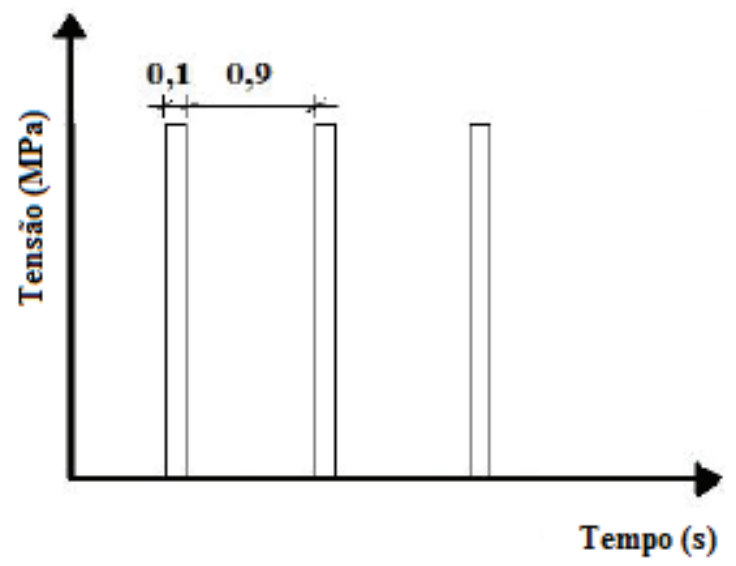

Figura 22 - Tempo de carregamento e descarregamento do creep dinâmico.

Análogo ao creep estático, o deslocamento axial sofrido pelo corpo de prova, em função da solicitação da carga de ensaio, gera a curva de fluência do material e e é possível calcular os seguintes parâmetros das misturas asfálticas: deformação total, módulo de fluência e inclinação média do estágio secundário da curva de deformação versus tempo de carregamento.

Os dados de ensaios foram compilados por uma ferramenta computacional desenvolvida na plataforma LabView $7.1^{\circledR}$, elaborada pelo Prof. Dr. Glauco Tulio Pessa Fabbri da Escola de Engenharia de São Carlos. 


\subsection{ANÁLISE E TRATAMENTO DE DADOS}

Os dados obtidos na compactação giratória e nos ensaios de creep em um primeiro momento foram analisados separadamente, a fim de se considerar os efeitos isolados de cada fator sobre os parâmetros adotados neste estudo para interpretação do comportamento dos cimentos asfálticos. Concluída esta etapa, os valores de compactação e creep foram confrontados, com o intuito de se observar a existência de relações entre estas variáveis. As regressões foram ajustadas para a representação da eventual relação entre compacidade e deformação permanente. E a medida de ajustamento ao modelo para esta avaliação foi o coeficiente de determinação (R- quadrado). Os dados e gráficos foram gerenciados pela planilha eletrônica Excel do Microsoft Office. 
CAPITULO 5

\section{APRESENTAÇÃO E ANÁLISE DE DADOS}

\subsection{CONSIDERAÇÕES INICIAIS}

Nesta etapa, são apresentados os resultados dos parâmetros obtidos nos ensaios de creep estático e dinâmico, além do levantamento das curvas de densificação e dados da compactação giratória. Em um primeiro momento, foi realizada uma análise isolada dos ensaios de compactação e creep. Em um segundo, momento realizou-se um estudo comparativo, levando em conta o efeito de cada condição experimental em relação aos parâmetros obtidos nos ensaios. Em um terceiro momento, os valores dos índices obtidos na compactação giratória foram confrontados com os resultados dos ensaios de propriedades mecânicas, a fim de entender se estes índices relacionados podem indicar alguma relação com o desenvolvimento da deformação permanente em misturas asfálticas. E ainda indicou-se qual condição experimental apresenta melhor desempenho quanto à resistência ao aparecimento de deformações permanentes.

Foi realizado o controle de qualidade dos ensaios, adotando o coeficiente de variação (desvio padrão/média $\times 100$ ) dos corpos de prova, como indicador da confiabilidade dos resultados no grupo (CE) e com valor máximo de $20 \%$.

Em suma, o esquema de apresentação e análise de dados é:

i) Comportamento das misturas asfálticas na compactação;

ii) Desempenho das misturas asfálticas nos ensaios de propriedades mecânicas;

iii) Análise do comportamento das misturas;

iv) Relações entre propriedades de compactação e propriedades dos ensaios de previsão de deformação permanente.

A fim de facilitar a identificação das diversas misturas asfálticas estudadas, na análise de dados, foram adotadas as nomenclaturas apresentadas na Tabela 9. 
Tabela 9 - Nomenclatura das misturas asfálticas da pesquisa.

\begin{tabular}{|c|c|c|c|c|}
\hline $\begin{array}{l}\text { Condição } \\
\text { experimental }\end{array}$ & Composição & Vv (\%) & Cal & Nomenclatura \\
\hline 1 & CAP 50-70 & 4 & Sim & M1 \\
\hline 2 & CAP 50-70 & 4 & Não & M2 \\
\hline 3 & Stylink $^{\circledR}$ & 4 & Sim & M3 \\
\hline 4 & Stylink $^{\circledR}$ & 4 & Não & M4 \\
\hline 5 & CAP 50-70 & 7 & Não & M5 \\
\hline 6 & CAP 50-70 & 7 & Sim & M6 \\
\hline 7 & Stylink ${ }^{\circledR}$ & 7 & Não & M7 \\
\hline 8 & Stylink $^{\circledR}$ & 7 & Sim & M8 \\
\hline
\end{tabular}

Neste capítulo, os cálculos foram processados com o auxílio da planilha eletrônica do Microsoft Excel assim como os gráficos, com exceção de alguns que foram processados em planilha eletrônica do programa computacional Origin.

\subsection{PARÂMETROS ORIUNDOS DA COMPACTAÇÃO}

Os índices de compactação para cada "família" de misturas asfálticas são valores médios do conjunto de corpos de prova. Para aquisição destes parâmetros (CDI, TDI $\mathrm{m}$ e Locking Point) primeiramente foi necessário traçar as curvas de densificação, ilustradas pelas Figura 23 e 24, que foram obtidas pela relação porcentagem de densificação $\left(\% \mathrm{G}_{\mathrm{mm}}\right)$ por número de giros.

Analisando as curvas de densificação, é possível observar que para as misturas asfálticas de $V v=4 \%$ a "família" $M 4$, de menor inclinação da curva, ofereceu maior resistência a compactação que as demais M1, M2 e M3. Desta forma pode-se concluir que o ligante modificado na composição dessa mistura asfáltica ofereceu maior resistência à densificação. No entanto, de forma geral as quatro curvas de densificação apresentadas na Figura 23 estão próximas, o que remete à um comportamento semelhante quanto à compactação.

Já para as misturas compactadas em $7 \%$ de volume de vazios, a mistura asfáltica M7, de maior inclinação da curva, compactou-se com maior facilidade que as demais M5, M6 e M8. Observa-se então que misturas asfálticas densas compostas de ligante asfáltico modificado e com adição de cal compactou-se com 
maior facilidade que as demais misturas asfálticas em estudo. Entretanto, diante das quatro curvas de compactação apresentadas na Figura 24, conclui-se que as misturas asfálticas comportam-se de forma similar na compactação.

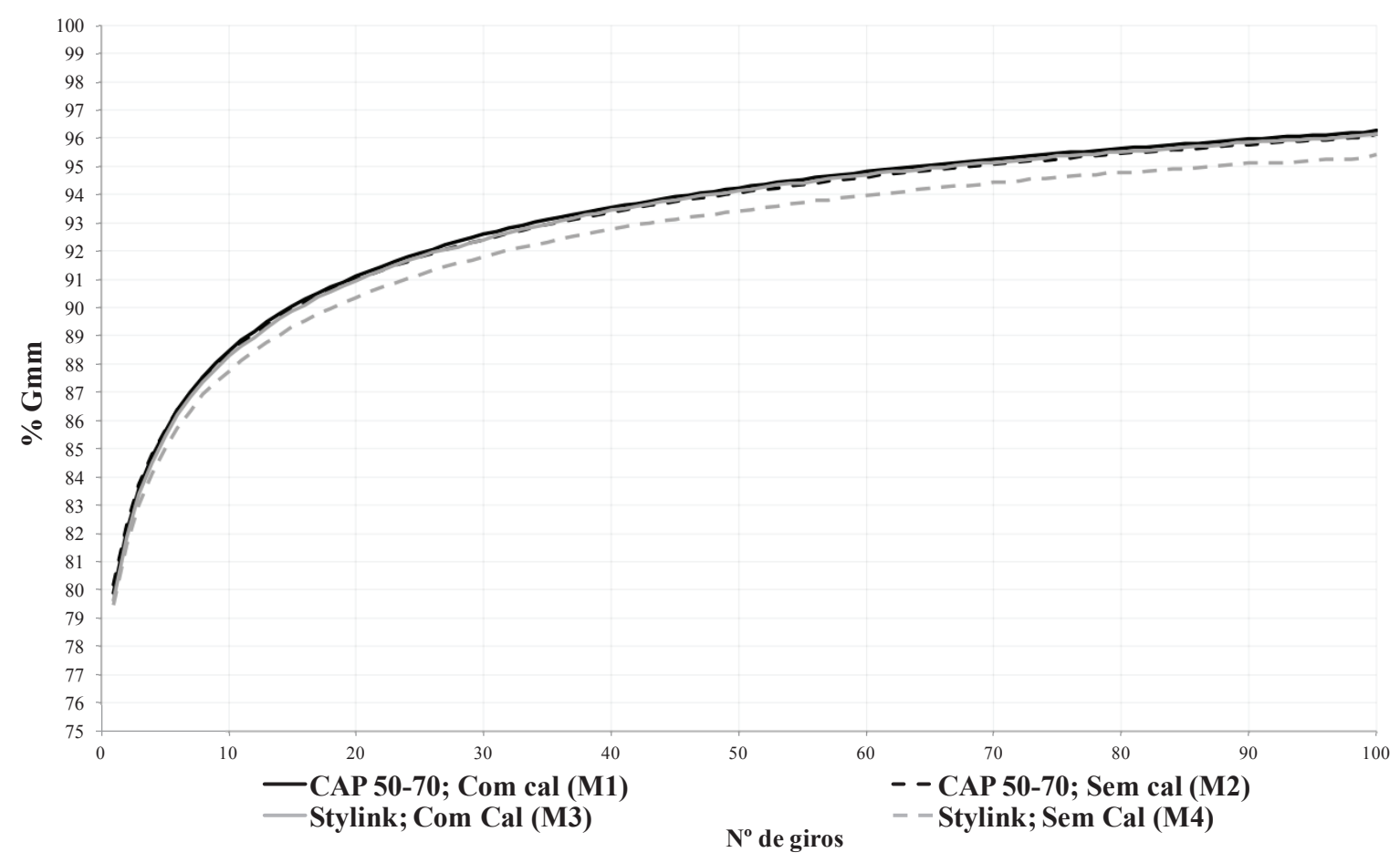

Figura 23 - Curvas de densificação para misturas com $V v=4 \%$.

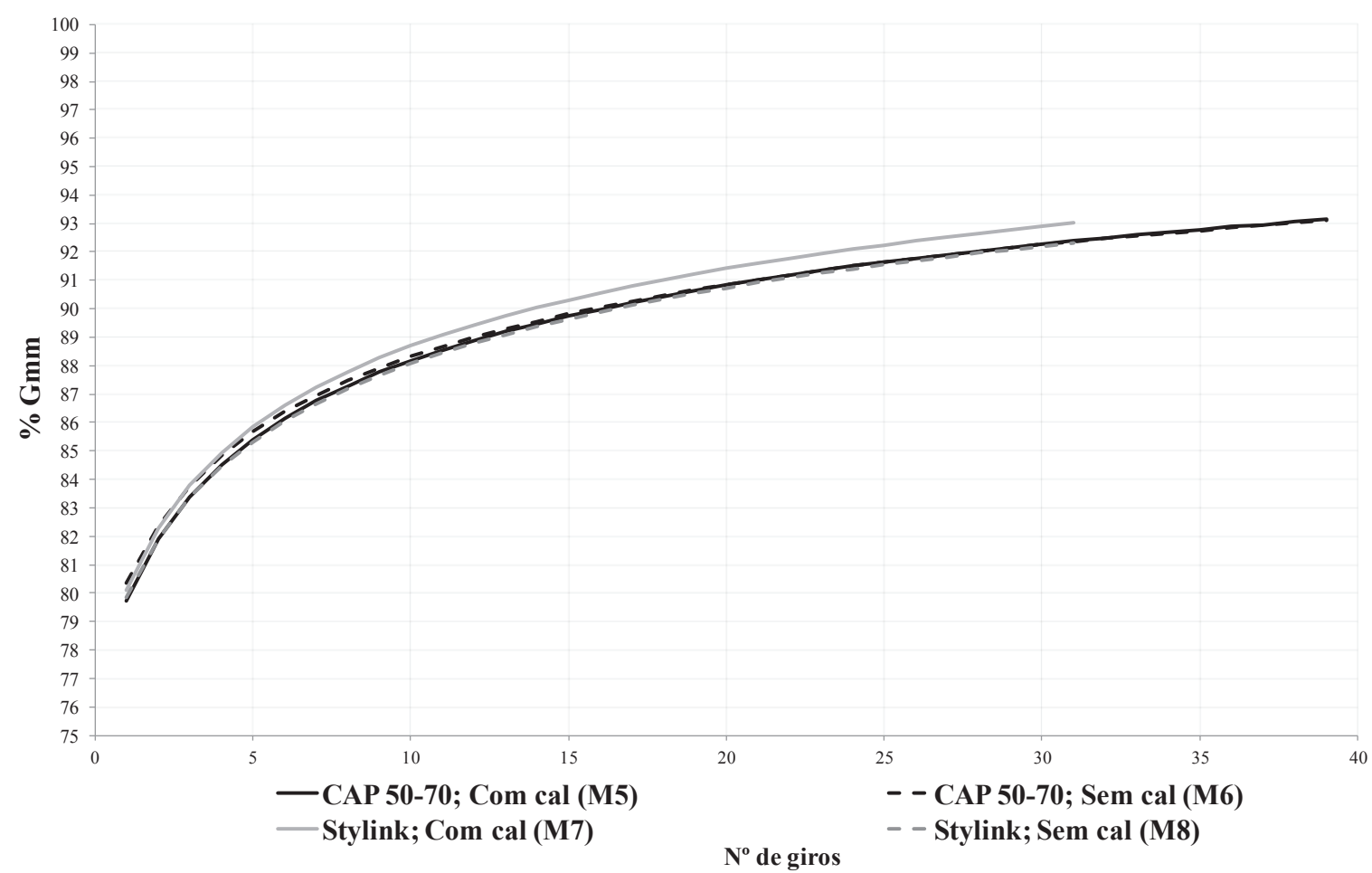

Figura 24 - Curvas de densificação para misturas com $V v=7 \%$. 
Para melhor compreender o desenvolvimento da compactação nos corpos de prova ensaiados, foi calculada a inclinação da curva de densificação (I curva $_{\text {). Esta }}$ variável foi obtida calculando-se a cotangente da relação entre o intervalo da curva

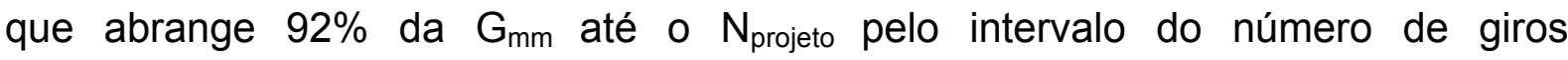
correspondente a este intervalo.

Na Tabela 10, são mostrados os valores médios e para melhor compreensão destes resultados é apresentado também a Figura 25.

Tabela 10 - Valores médios para inclinação da curva de compactação.

\begin{tabular}{cccc}
\hline Mistura & Composição & Vv\% & I curva \\
\hline M1 & CAP 50-70 + cal & 4 & 0,058 \\
M2 & CAP 50-70 & 4 & 0,055 \\
M3 & Stylink $^{\circledR}+$ cal & 4 & 0,055 \\
M4 & Stylink $^{\circledR}$ & 4 & 0,054 \\
M5 & CAP 50-70 & 7 & 0,092 \\
M6 & CAP 50-70 + cal & 7 & 0,105 \\
M7 & Stylink $^{\circledR}$ & 7 & 0,103 \\
M8 & Stylink $^{\circledR}+$ cal & 7 & 0,140 \\
\hline
\end{tabular}

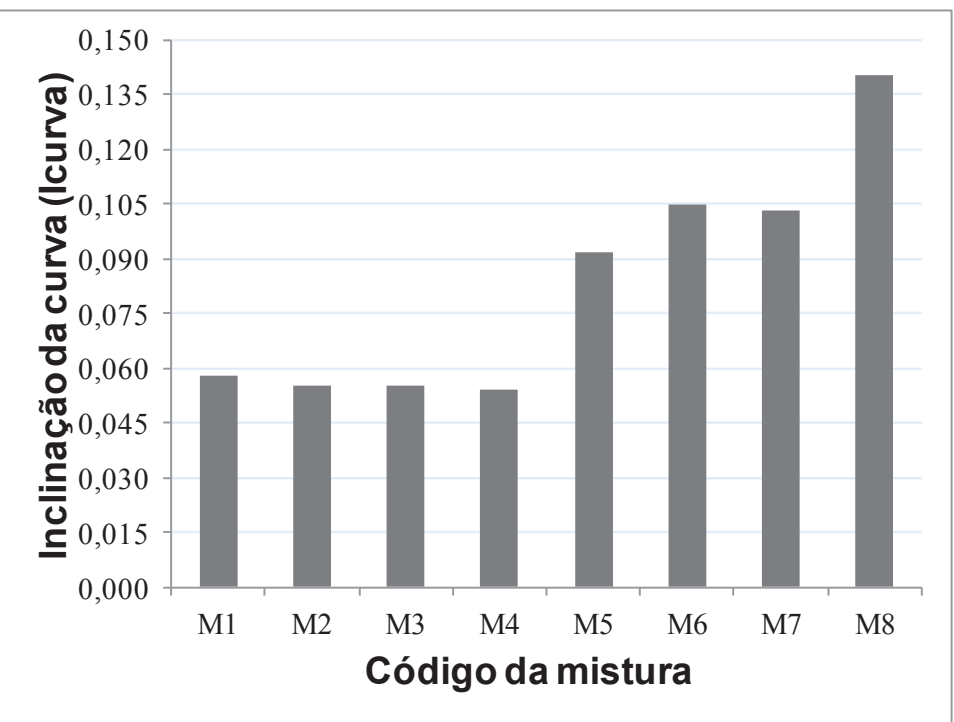

Figura 25 - Valores médios para inclinação da curva de densificação. 
Baseado nos resultados apresentados é possível afirmar que a mistura asfáltica M4 apresentou o menor valor de $I_{\text {curva }}$ enquanto a mistura M8 obteve o maior valor. Segundo as literaturas consultadas uma inclinação elevada pode dar indícios que o material ofereça menor resistência à compactação.

Quando a densificação é acelerada nos ciclos iniciais deste processo, a curva de densificação tende apresentar inclinação suave. No caso deste estudo, o percentual de volume de vazios exerceu grande influência sobre os valores deste parâmetro, pois misturas asfálticas compactadas em $7 \%$ de volume de vazios mostraram maiores valores para $I_{\text {curva }}$ indicando uma maior velocidade na compactação para estas composições de misturas asfálticas.

\subsubsection{Compaction Densification Index (CDI) e Traffic Densification Index (TDI)}

O parâmetro CDI foi calculado para as 8 misturas asfálticas do estudo, enquanto o índice $\mathrm{TDI}_{m}$ foi obtido somente para misturas asfálticas de volume de vazios igual à $4 \%$. Isto porque para se calcular o $\mathrm{TDI}_{\mathrm{m}}$ é necessário que o corpo de prova seja compactado até o $\mathrm{N}_{\text {projeto }}(100)$. No entanto, os corpos de prova moldados a $7 \%$ de volume de vazios não chegam ao número de giros de projeto.

São apresentadas nas Tabelas 11 e 12, os valores médios de CDI e TDI para todas as misturas asfálticas desta pesquisa. Pra melhor visualização dos resultados são apresentadas também as Figuras 26 e 27.

Tabela 11 - Valores de CDI e TDIm para misturas asfálticas com Vv=4\%.

\begin{tabular}{cccc}
\hline Mistura & Composição & CDI & TDIm \\
\hline M1 & CAP 50-70 + cal & 47 & 198 \\
M2 & CAP 50-70 & 53 & 183 \\
& & & \\
M3 & Stylink + cal & 53 & 194 \\
M4 & Stylink & 67 & 166 \\
\hline
\end{tabular}


Tabela 12 - Valores de CDI para misturas asfálticas com $V v=7 \%$.

\begin{tabular}{ccc}
\hline Mistura & Composição & CDI \\
\hline M5 & CAP 50-70 & 66 \\
M6 & CAP 50-70 + cal & 63 \\
M7 & Stylink & 68 \\
M8 & Stylink + cal & 42 \\
\hline
\end{tabular}

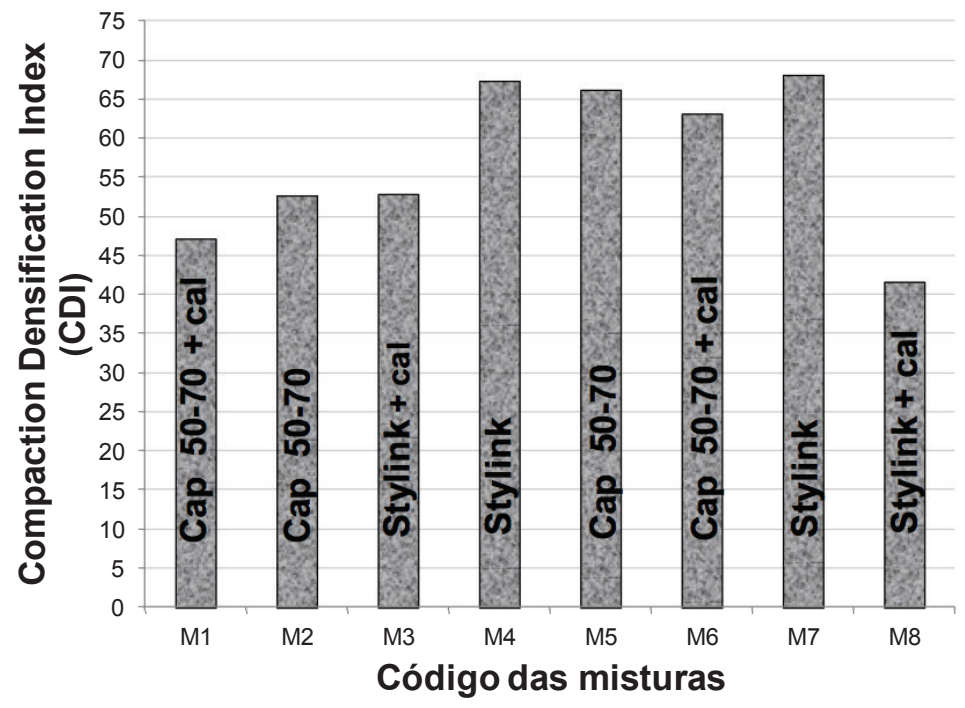

Figura 26 - Valores de CDI das 8 misturas asfálticas testadas.

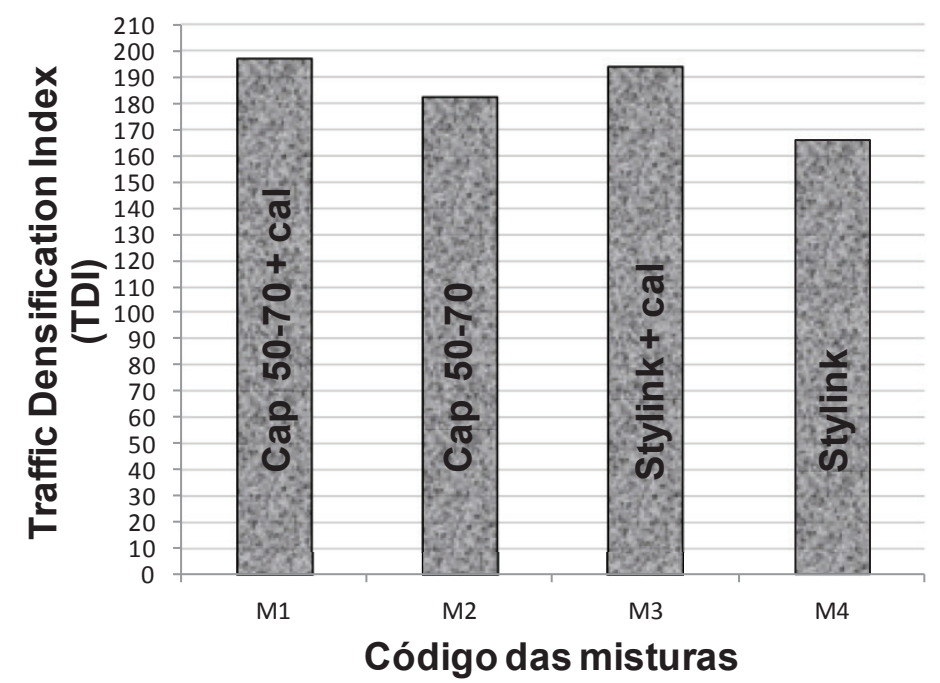

Figura 27 - Valores de TDIm para misturas asfálticas de $V v=4 \%$. 
Os valores obtidos de CDI e TDI $\mathrm{m}$ para as misturas asfálticas apresentaram diferenças entre si. O maior valor de CDI alcançado foi para a mistura $M 7$, porém a mistura M4 apresentou valor muito próximo. Ambas são compostas pelo ligante asfáltico modificado Stylink e sem adição de cal. Segundo Mahmoud e Bahia (2004), quanto maior o valor de CDI, maior é a quantidade de energia necessária para se compactar a mistura asfáltica durante a fase de construção da rodovia. Já o menor valor de CDI obtido foi para a mistura M8, sua composição é de ligante asfáltico Stylink, com adição de cal. Esta mistura exigiria menor esforço de compactação na fase de construção.

Considerando que as temperaturas de compactação foram estritamente respeitadas e analisando a influência das condições experimentais em relação aos valores encontrados para o índice Compaction Densification Index, observou-se que:

i) As misturas asfálticas com ligante asfáltico modificado apresentaram os maiores valores para CDI, porém esta constatação somente vale quando não há o aditivo cal;

ii) A adição de cal hidratada, de forma geral, atuou na forma de reduzir os valores de CDI, as misturas asfálticas com adição de cal apresentaram os menores valores de CDI;

iii) $O$ volume de vazios influenciou no parâmetro CDI, em $7 \%$ de volume de vazios, foram obtidos maiores valores.

Nascimento (2008) recomenda que para rodovias de tráfego médio ou alto, o valor de CDI deve ser maior que 50. Seguindo esta recomendação, as condições experimentais representadas por M1 e M8 não satisfazem este princípio.

No que se refere ao parâmetro TDI $\mathrm{m}$, o maior valor obtido foi para mistura M1, composta por ligante asfáltico convencional e com adição de cal. O que indica uma certa resistência à densificação pelas cargas de tráfego ao longo da vida de serviço para esta composição de camada asfáltica. O menor valor apresentado de $\mathrm{TDI}_{\mathrm{m}}$ foi para a condição M4, composta por ligante asfáltico modificado e sem o aditivo cal. Neste caso, M4 ofereceria menor resistência à compactação pelo tráfego.

Observando-se a relação entre os fatores experimentais e os índices Traffic Densification Index, foi possível observar que:

i) Para as misturas betuminosas com ligante asfáltico convencional, valores maiores deste índice foram alcançados; 
ii) A adição de cal hidratada elevou os valores deste parâmetro.

A partir destas constatações pode-se interpretar que a combinação dos fatores CAP 50-70 + cal pode dar origem a misturas asfálticas mais resistentes ao desenvolvimento da trilha de roda, visto que as tornam mais resistentes às cargas de tráfego.

Em relação ao comportamento típico dos parâmetros CDI e TDI, são desejáveis valores baixos de CDI e valores elevados de TDI, indicando que a mistura asfáltica necessita de pouca energia para a densificação e que possui resistência às solicitações de cargas em serviço. Neste caso, a mistura asfáltica M1 composta por ligante asfáltico convencional e com adição de cal, foi a que mais se aproximou em satisfazer estes princípios. Uma vez que o valor de CDI obtido para esta mistura foi um dos menores e o TDI $\mathrm{m}$ foi o maior das composições estudadas.

Nascimento (2008) indica valor de TDI $\mathrm{m}$ para tráfego médio superior a $250 \mathrm{e}$ para tráfego pesado maior que 400. Baseado nesta recomendação pode-se concluir que das quatro condições experimentais para as quais foram calculados este índice, nenhuma alcançou o valor mínimo de 250.

\subsubsection{Locking Point}

O parâmetro LP foi calculado para as misturas compactadas para $4 \%$ de volume de vazios. Os conceitos utilizados nesta pesquisa foram os de: Pine (1997) e Vavrick e Carpenter (1998). São apresentados na Tabela 13 valores de LP encontrados em termos médios e para melhor apreciação destes resultados é apresentada a Figura 28.

Tabela 13 - Valores médios de LP para as misturas asfálticas de $\mathrm{Vv}=4 \%$.

\begin{tabular}{cccc} 
Mistura & Composição & LP1 (Pine) & LP2 (Vavrik) \\
\hline M1 & Cap 50-70 + cal & 53 & 53 \\
M2 & Cap 50-70 & 50 & 52 \\
M3 & Stylink $^{\circledR}+$ cal & 53 & 53 \\
M4 & Stylink $^{\circledR}$ & 50 & 53 \\
\hline
\end{tabular}




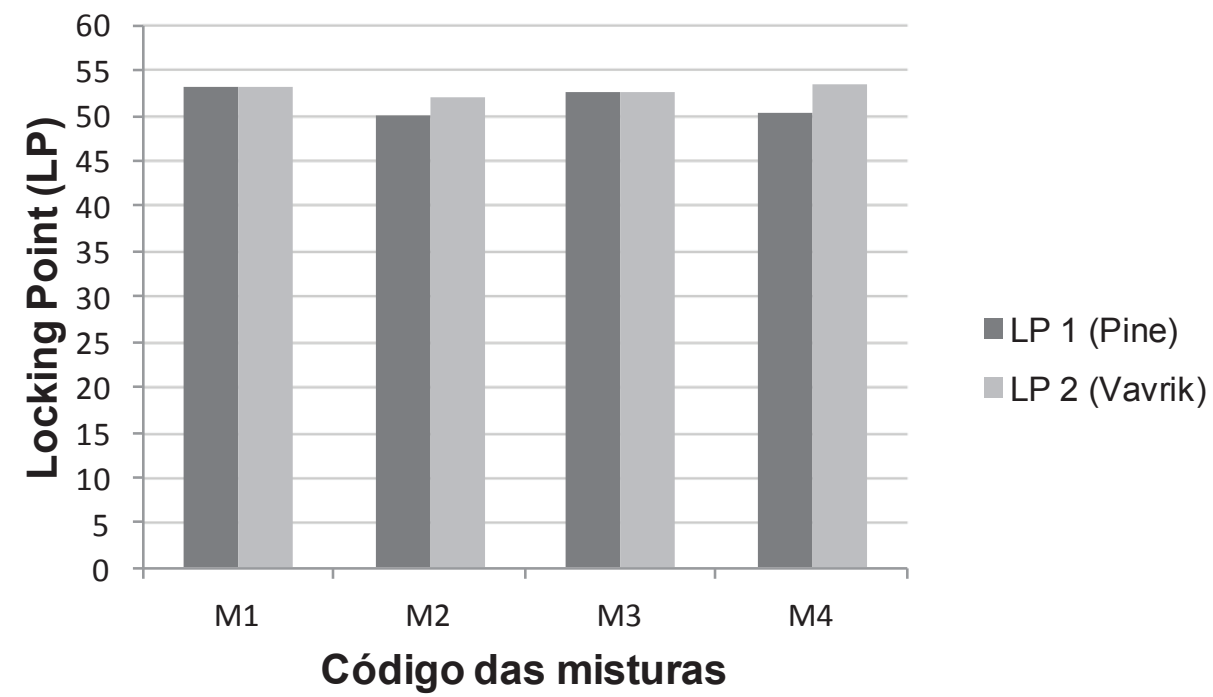

Figura 28 - Valores médios de LP para as misturas asfálticas de $V v=4 \%$.

Os dois métodos em que este estudo se baseou para determinar os LP's não tiveram diferenças expressivas em valor, pois estavam muito próximos um do outro. Desta forma, a fim de simplificar as análises optou-se por somente um LP e no caso foi escolhido o LP1, calculado nos princípios de Pine.

Na Tabela 14, estão expostos os percentuais de volumes de vazios no início e fim da compactação no CGS, além do $\vee v \%$ no número de giros do locking point.

Tabela 14 - Volumes de vazios inicial/no LP/final, na compactação.

\begin{tabular}{cccccc}
\hline Mistura & Composição & LP 1 (Pine) & Vv\%inicial & Vv\% LP & Vv\% final \\
\hline M1 & Cap 50-70 + cal & 53 & 20,1 & 5,6 & 3,7 \\
M2 & Cap 50-70 & 50 & 20,0 & 6,2 & 4,1 \\
M3 & Stylink + cal & 53 & 20,3 & 5,7 & 3,8 \\
M4 & Stylink & 50 & 20,1 & 6,0 & 4,0 \\
\hline
\end{tabular}

O percentual de volume de vazios de $4 \%$ que foi designado para as misturas asfálticas M1, M2, M3 e M4 não foi atingido no giro do LP. No entanto, ao fim da compactação, o volume de vazios final mostrou que as misturas com adição de cal (M1 e M3), compactaram além do exigido, o que remete a um gasto de energia desnecessário ao levar este processo de densificação até o $\mathrm{N}_{\text {projeto }}$. 
Considerando os volumes de vazios inicial, no LP e final, nota-se que a partir do número de giro no locking point pouca compactação adicional ocorre. No LP, que

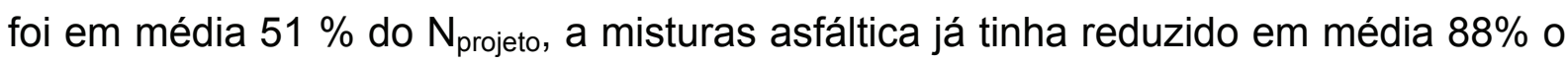
volume de vazios para se alcançar o desejado. Estas observações vieram corroborar com o conceito de locking point, pois ficou evidente que a partir do LP os agregados minerais da mistura asfálticas arranjaram-se de uma forma que dificultou a densificação a partir deste ponto.

Quanto ao efeito dos fatores experimentais em relação ao comportamento da variável LP, é possível observar que as misturas asfálticas M2 e M4 alcançaram o locking point antes de M1 e M3, indicando uma estabilização mais rápida em misturas asfálticas sem a adição de cal em sua constituição em relação às demais. No entanto, não foi observada a influência da mudança do tipo de ligante asfáltico or nos resultados de locking point.

\subsection{CREEP ESTÁTICO}

Os ensaios de creep estático foram realizados nas temperaturas de 40 e $50^{\circ} \mathrm{C}$, sob tensão de 0,4 MPa. Neste item as discussões sobre o comportamento das misturas asfálticas foram realizadas tomando por base os parâmetros: deformação total $\left(D_{T}\right)$, módulo de fluência $\left(M_{F}\right)$, inclinação da curva $\left(I_{\text {curva }}\right)$ e recuperação.

O módulo de fluência $\left(\mathrm{M}_{\mathrm{F}}\right)$ apresentado foi obtido para o tempo de $3600 \mathrm{~s}$, que é referente ao tempo total de aplicação de carga. O $M_{F}$ de $4500 \mathrm{~s}$ (referente ao tempo total de carga somado no período de recuperação) foi descartado pela pesquisa devido à alta taxa de variação entre os valores encontrados, o que foi atribuído como baixa confiabilidade destes resultados.

Nas Tabelas 15 e 16 são apresentados os valores médios dos parâmetros de creep estático entre obtidos entre duas réplicas. 
Tabela 15 - Valores médios dos parâmetros de ensaio de Creep Estático $40^{\circ} \mathrm{C}$.

\begin{tabular}{c|l|c|c|c|c}
\hline $\begin{array}{c}\text { Mistura } \\
\text { asfáltica }\end{array}$ & Composição & $\begin{array}{c}\text { Def. Total } \\
(\mathbf{m m} / \mathbf{m m})\end{array}$ & $\begin{array}{c}\text { Recuperação } \\
(\%)\end{array}$ & $\begin{array}{c}\text { Mód. Fluência } \\
\text { (MPa) }\end{array}$ & $\mathrm{I}_{\text {curva }}$ \\
\hline M1 & CAP 50-70+cal & 0,0016 & 87 & 249,2 & 0,0167 \\
M2 & CAP 50-70 & 0,0007 & 100 & 521,7 & 0,0814 \\
M3 & Stylink $^{\oplus}+$ cal & 0,0008 & 100 & 517,2 & 0,1122 \\
M4 & Stylink $^{\oplus}$ & 0,0009 & 100 & 457,3 & 0,0781 \\
\hline M5 & CAP 50-70 & 0,0015 & 100 & 259,4 & 0,0854 \\
M6 & CAP 50-70 +cal & 0,0014 & 100 & 305,0 & 0,0853 \\
M7 & Stylink $^{\circledast}$ & 0,0011 & 100 & 370,8 & 0,1414 \\
M8 & Stylink $^{\circledast}+$ cal & 0,0010 & 100 & 391,1 & 0,1458 \\
\hline
\end{tabular}

Tabela 16 - Valores médios dos parâmetros de ensaio de Creep Estático $50^{\circ} \mathrm{C}$.

\begin{tabular}{c|l|c|c|c|c}
\hline $\begin{array}{c}\text { Mistura } \\
\text { asfáltica }\end{array}$ & Composição & $\begin{array}{c}\text { Def. Total } \\
(\mathbf{m m} / \mathbf{m m} \mathbf{)}\end{array}$ & $\begin{array}{c}\text { Recuperação } \\
\mathbf{( \% )}\end{array}$ & $\begin{array}{c}\text { Mód. Fluência } \\
\mathbf{( M P a )}\end{array}$ & $\mathbf{I}_{\text {curva }}$ \\
\hline M1 & CAP 50-70+cal & 0,0014 & 94 & 286,5 & 0,0254 \\
M2 & CAP 50-70 & 0,0019 & 82 & 200,5 & 0,0290 \\
M3 & Stylink $^{\circledR}+$ cal & 0,0017 & 72 & 235,6 & 0,0310 \\
M4 & Stylink $^{\circledR}$ & 0,0015 & 70 & 265,4 & 0,0339 \\
\hline \multirow{2}{*}{ M5 } & CAP 50-70 & 0,0029 & 53 & 134.0 & 0,1746 \\
M6 & CAP 50-70+cal & 0,0026 & 63 & 148,6 & 0,0313 \\
M7 & Stylink $^{\circledR}$ & 0,0019 & 76 & 207,2 & 0,0162 \\
M8 & Stylink $^{\circledR}+$ cal & 0,0017 & 84 & 234,8 & 0,0312 \\
\hline
\end{tabular}

Em análise preliminar da Tabela 15 é possível notar que a mistura asfáltica M1, apresentou o maior valor de deformação total e a mistura asfáltica M2 o menor valor. No geral, misturas asfálticas com maior volume de vazios $(7 \%)$ apresentaram maiores valores para $D_{\text {T. }}$ Enquanto na Tabela16, é possível verificar que novamente os maiores valores para deformação total ficou entre as misturas asfálticas de $7 \%$ de volume de vazios. O maior valor de $\mathrm{D}_{\mathrm{T}}$ ficou para M5 e o menor para M1.

É possível observar também que os parâmetros $D_{T}$ e $M_{F}$ mostraram uma relação inversa tanto para o ensaio de $40^{\circ} \mathrm{C}$ quanto para $50^{\circ} \mathrm{C}$. Isto é, à medida que o $M_{F}$ é maior, menores foram os valores de $D_{T}$ das misturas testadas.

No creep estático à $40^{\circ} \mathrm{C}$ a recuperação manteve-se em $100 \%$, com exceção da mistura asfáltica M1, composta de CAP 50/70 + cal, mas que ainda assim esteve 
bem próximo da recuperação total. Na temperatura de $50^{\circ} \mathrm{C}$ foi possível observar que a adição de cal às misturas asfálticas influenciou de forma positiva na recuperação.

As inclinações das curvas para as duas condições de temperatura de ensaio para o creep estático indicaram um aumento na velocidade de deformação para as misturas asfálticas com adição de cal, com exceção da mistura M1. Há uma tendência também das misturas com ligante modificado apresentarem maior velocidade deformação, com exceção da mistura M7.

Em suma, dos resultados apresentados na temperatura de $40^{\circ} \mathrm{C}$ destacaram as misturas M2, M3 e M4 por apresentarem baixos valores de deformação total (bem próximos entre si) e maiores módulos de fluência, além de se recuperarem em $100 \%$. Na temperatura de $50^{\circ} \mathrm{C}$ a mistura asfáltica M1 se destacou por alcançar o menor valor de $D_{T}$ e maior valor de $M_{F}$, além de apresentar a melhor recuperação (94\%). Examinando-se todas as composições é possível afirmar que o fator volume de vazios exerceu maior influência no desempenho das misturas asfálticas, pois de forma geral à $4 \%$ de volume de vazios a $D_{T}$ foi menor e $M_{F}$ maior.

\subsubsection{Análise dos efeitos isolados}

Neste subitem, cada condição do experimento foi estudada separadamente, a fim de examinar o comportamento de cada constituição de mistura asfáltica em relação à cada índice do creep estático.

\subsubsection{Volume de vazios}

A partir dos dados de ensaio, verificou-se a influência da variação de volume de vazios no comportamento das misturas asfálticas. Primeiramente, é possível notar um aumento da deformação total em misturas com volume de vazios de $7 \%$ quando comparadas as de $V v=4 \%$, mostrando uma relação direta entre estes critérios de análise, ou seja, quanto maior o volume de vazios maior o desenvolvimento da deformação total. $\mathrm{Na}$ menor temperatura de ensaio $\left(40^{\circ} \mathrm{C}\right)$, o aumento observado na deformação em termos médios foi da ordem de $20 \%$. Enquanto à $50^{\circ} \mathrm{C}$ houve um aumento expressivo na $\mathrm{D}_{\mathrm{T}}$, em torno de $38 \%$. 
No geral, a recuperação das misturas asfálticas foi satisfatória. Porém foi observado um comportamento divergente nas misturas asfálticas de mesmo volume de vazios e em temperaturas diferentes, mesmo que em valor pouco expressivo. Em $40^{\circ} \mathrm{C}$ houve um aumento na recuperação de $3 \%$ ao aumentar-se o percentual de vazios, o que pode ser considerado o mesmo comportamento na recuperação para os dois cenários ( $4 \%$ e $7 \%$ de $\mathrm{Vv}$ ). No entanto, no ensaio à $50^{\circ} \mathrm{C}$ ao elevar-se $\mathrm{o}$ volume de vazios houve um decréscimo de $10 \%$ na recuperação. Mais uma vez o aumento da temperatura em combinação com o aumento de volume de vazios de 4 para $7 \%$ destaca os efeitos deletérios. Explica-se esse processo pela perda de rigidez do asfalto, em função do aumento de temperatura.

Quanto ao módulo de fluência, houve uma tendência em obter maiores valores para misturas betuminosas moldadas com $V v=4 \%$. Consequentemente, ao aumentar-se o volume de vazios o módulo de fluência diminui, na menor temperatura de ensaio o decréscimo no $\mathrm{M}_{\mathrm{F}}$ em valores médios foi de $25 \%$, enquanto na maior temperatura o decréscimo foi de $27 \%$. Esta constatação veio corroborar com alguns estudos que informam a relação inversa entre $M_{F}$ versus $D_{T}$.

A inclinação da curva demonstrou grande sensibilidade ao aumento de volume de vazios. Grandes variações foram encontradas quando variou-se o volume de vazios de $4 \%$ para $7 \%$. No ensaio à $40^{\circ} \mathrm{C}$ houve acréscimo de $59 \%$ da inclinação da curva enquanto à $50^{\circ} \mathrm{C}$ o aumento de $112 \%$. Pode-se entender que misturas asfálticas com $7 \%$ de volume de vazios possuem maior velocidade de deformação se comparadas às misturas asfálticas compactadas para $4 \%$ de volume de vazios.

Por fim, é apresentada a Tabela 17 com o intuito de sintetizar o comportamento dos parâmetros de creep estático quanto a variação do volume de vazios.

Tabela 17 - Quadro resumo das análises realizadas sobre os efeitos do aumento do volume de vazios de $4 \%$ para $7 \%$.

\begin{tabular}{lcc}
\hline \multicolumn{1}{c}{ Parâmetros } & \multicolumn{2}{c}{ Aumento do volume de vazios } \\
& Efeito à $\mathbf{4 0 ^ { \circ } \mathrm { C }}$ & Efeito à $50^{\circ} \mathrm{C}$ \\
\hline Deformação Total & aumenta & aumenta \\
Recuperação & aumenta & diminui \\
Módulo de Fluência & diminui & diminui \\
Inclinação da curva & aumenta & aumenta \\
\hline
\end{tabular}




\subsubsection{Ligante asfáltico}

Ao longo deste subitem são discutidos os efeitos do ligante asfáltico convencional e modificado por polímero sobre os índices obtidos nos ensaios de creep estático nas temperaturas de $40^{\circ} \mathrm{C}$ e $50^{\circ} \mathrm{C}$. De forma geral não foram observadas tendências muito claras no comportamento dos parâmetros.

No que diz à respeito da deformação total, misturas asfálticas com ligante modificado por SBS apresentaram menores valores que as com ligante asfáltico convencional, cerca de $22 \%$ em média. O maior percentual de redução da $D_{T}$ encontrado foi o de $50 \%$ para a mistura asfáltica M3 (Stylink e cal) se comparada com a mistura M1(CAP 50-70 e cal). Uma explicação razoável seria que os polímeros tornam as misturas asfálticas mais resistentes às deformações. No entanto, a interação dos efeitos do polímero SBS com a cal demonstrou-se prejudicial à resistência à deformação permanente.

Nenhum comportamento foi observado para o parâmetro recuperação, pois eles são divergentes entre si e não obedecem a uma lógica que esteja clara.

O módulo de fluência exibiu maiores valores em misturas asfálticas com Stylink $^{\circledR}$, com exceções das composições M4 no ensaio à $40^{\circ} \mathrm{C}$ e a $\mathrm{M} 3$ no ensaio à $50^{\circ} \mathrm{C}$. Na média houve um aumento de $8 \%$ que pode ser considerado inexpressivo.

Ao analisar-se a inclinação da curva de fluência não ficou muito evidente o comportamento deste parâmetro, pois hora ele aumentava e hora diminuía para o mesmo tipo de ligante asfáltico. Fazendo-se uma média geral, a misturas asfáltica com ligante modificado por polímero demonstrou uma pequena tendência de alcançar maiores inclinações, cerca de 12\% acima do valor médio das misturas asfálticas convencionais.

Em suma não foram encontradas tendências muito evidentes no comportamento dos parâmetros de ensaio com relação à adição do polímero SBS ao ligante das misturas asfálticas. Porém, com a finalidade de resumir as análises e discussões realizadas, é apresentada a Tabela 18. 
Tabela 18 - Quadro resumo das análises realizadas sobre os efeitos da adição do SBS ao ligante asfáltico.

\begin{tabular}{lcc}
\hline \multicolumn{1}{c}{ Parâmetros } & $\begin{array}{c}\text { Mistura } \\
\text { convencional }\end{array}$ & Mistura modificada \\
\hline Deformação Total & maior & menor \\
Recuperação & inconclusivo & inconclusivo \\
Módulo de Fluência & menor & maior \\
Inclinação da curva & menor & maior \\
\hline
\end{tabular}

Mais uma vez a deformação total mostrou sua relação inversa em relação ao módulo de fluência.

\subsubsection{Adição de cal}

A partir dos dados dos ensaios de creep estático, são discutidos os efeitos da adição de $1,5 \%$ de cal hidratada às misturas asfálticas sobre a deformação permanente. Porém a influência da cal sobre os parâmetros de ensaio não ficou muito evidente.

Examinando os valores para cada tipo de mistura asfáltica, não foi identificada uma lógica no comportamento da variável deformação total. Fazendo-se uma média dos valores das composições com cal e sem cal, obteve-se um percentual de $23 \%$ de aumento da deformação total em misturas sem a adição de cal em relação aos com cal. Para a deformação total os valores médios foram iguais para ambos os cenários, com e sem cal.

Os parâmetros recuperação e módulo de fluência demonstraram pouco sensíveis à adição de cal às misturas asfálticas. Os valores médios para recuperação e módulo de fluência variaram em torno de $3 \%$, o que pode ser considerado desprezível. Entretanto, no ensaio à $50^{\circ} \mathrm{C}$ foi possível identificar que a adição de cal às misturas asfálticas influenciou de forma positiva na recuperação.

A adição de cal em misturas asfálticas convencionais reduziu em até $80 \%$ a inclinação da curva de fluência e na média 40\%, indicando assim uma menor velocidade de deformação. 
Com o intuito de resumir as observações em relação aos efeitos da cal sobre os parâmetros de creep, é apresentada a Tabela 19.

Tabela 19 - Quadro resumo das análises realizadas sobre os efeitos da adição de cal nas misturas asfálticas.

\begin{tabular}{lcc}
\hline \multicolumn{1}{c}{ Parâmetros } & Com cal & Sem cal \\
\hline Deformação Total & menor & maior \\
Recuperação & inconclusivo & inconclusivo \\
Módulo de Fluência & inconclusivo & inconclusivo \\
Inclinação da curva & menor & maior \\
\hline
\end{tabular}

\subsection{CREEP DINÂMICO}

O creep dinâmico, assim como o estático, foi realizado nas temperaturas de 40 e $50^{\circ} \mathrm{C}$, na tensão de 0,4 MPa. São apresentados neste item os parâmetros de ensaio: deformação total $\left(D_{T}\right)$, módulo de fluência $\left(M_{F}\right)$ e inclinação da curva ( $\left.I_{\text {curva }}\right)$. Foram realizadas análises preliminares referentes ao comportamento das variáveis deste ensaio.

Os resultados mostrados nas Tabelas 20 e 21 são valores obtidos a partir da média aritmética de dois corpos de prova para cada condição experimental. Para melhor apreciação dos resultados são apresentadas também as Figuras 29, 30 e 31 . É esperado que os parâmetros obtidos no creep dinâmico expressem melhor os efeitos dos polímeros, no caso desta pesquisa o SBS, em relação à deformação permanente.

Ao avaliar o comportamento dos parâmetros expostos na Tabela 20, nota-se que a maior deformação total foi exibida pela mistura asfáltica M5 e a menor pela M4. Enquanto na Tabela 21, a mistura asfáltica M5 novamente apresentou a maior $\mathrm{D}_{\mathrm{T}}$ e o menor valor foi o da M3. Ao comparar o ensaio de $40^{\circ} \mathrm{C}$ com o de $50^{\circ} \mathrm{C}$, conforme ilustrado na Figura 29, fica claro que no geral as misturas asfálticas submetidas à temperatura de $40^{\circ} \mathrm{C}$ apresentaram valores de deformação total inferiores aos ensaiados à $50^{\circ} \mathrm{C}$. Foi possível identificar também que misturas 
compostas por ligante asfáltico + SBS se deformaram menos que as misturas com asfalto convencional.

Tabela 20 - Valores médios dos parâmetros de ensaio de Creep Dinâmico $40^{\circ} \mathrm{C}$.

\begin{tabular}{ccccc}
\hline $\begin{array}{c}\text { Mistura } \\
\text { asfáltica }\end{array}$ & Composição & $\begin{array}{c}\text { Def. Total } \\
(\mathbf{m m} / \mathbf{m m})\end{array}$ & $\begin{array}{c}\text { Mód. Fluência } \\
(\mathbf{M P a})\end{array}$ & $\mathbf{I}_{\text {curva }}$ \\
\hline M1 & CAP 50-70 + cal & 0,0017 & 2378,1 & 0,3324 \\
M2 & CAP 50-70 & 0,0019 & 1962,1 & 0,3906 \\
M3 & Stylink + cal & 0,0009 & 3834,8 & 0,1982 \\
M4 & Stylink & 0,0008 & 4606,1 & 0,1791 \\
\hline M5 & CAP 50-70 & 0,0046 & 794,6 & 0,5330 \\
M6 & CAP 50-70 + cal & 0,0030 & 1187,0 & 0,4591 \\
M7 & Stylink & 0,0016 & 2316,0 & 0,289 \\
M8 & Stylink + cal & 0,0015 & 2407,3 & 0,3658 \\
\hline
\end{tabular}

Tabela 21 - Valores médios dos parâmetros de ensaio de Creep Dinâmico $50^{\circ} \mathrm{C}$.

\begin{tabular}{ccccc}
\hline $\begin{array}{c}\text { Mistura } \\
\text { asfáltica }\end{array}$ & Composição & $\begin{array}{c}\text { Def. Total } \\
(\mathbf{m m} / \mathbf{m m})\end{array}$ & $\begin{array}{c}\text { Mód. Fluência } \\
(\mathbf{M P a})\end{array}$ & $\mathrm{I}_{\text {curva }}$ \\
\hline M1 & CAP 50-70 + cal & 0,0071 & 587,7 & 0,5468 \\
M2 & CAP 50-70 & 0,0054 & 911,2 & 0,5358 \\
M3 & Stylink + cal & 0,0022 & 1691,6 & 0,4073 \\
M4 & Stylink & 0,0024 & 1511,8 & 0,4125 \\
\hline M5 & CAP 50-70 & 0,0281 & 130,4 & 0,4860 \\
M6 & CAP 50-70 + cal & 0,0248 & 144,9 & 0,9416 \\
M7 & Stylink & 0,0040 & 936,2 & 0,5225 \\
M8 & Stylink + cal & 0,0062 & 603,8 & 0,5797 \\
\hline
\end{tabular}




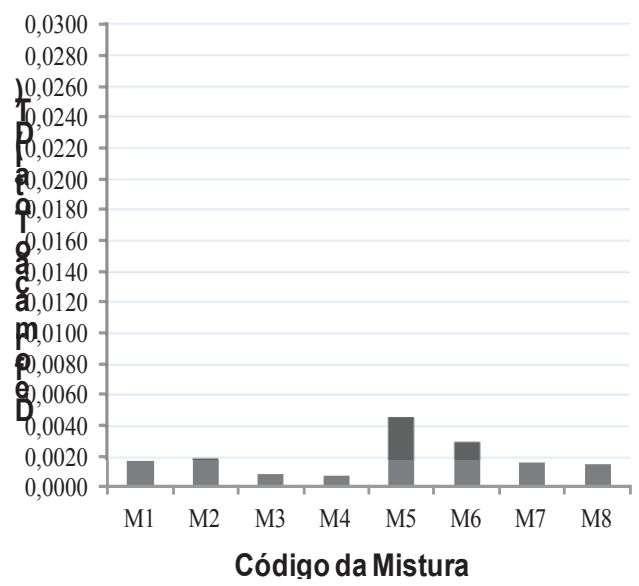

a) $40^{\circ} \mathrm{C}$

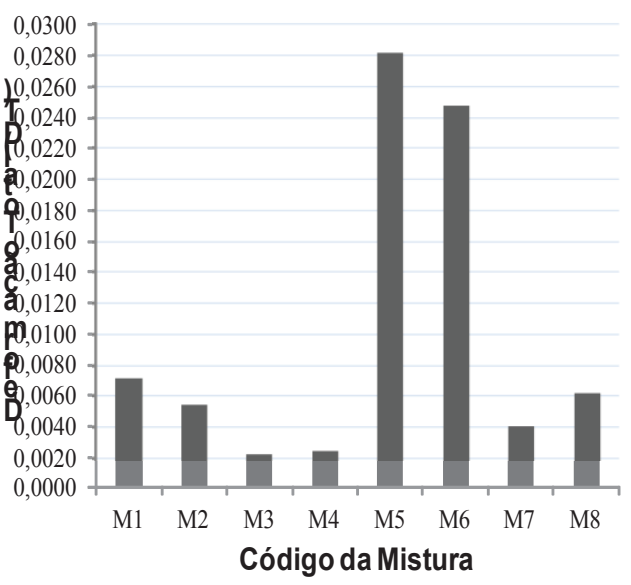

b) $50^{\circ} \mathrm{C}$

Figura 29 - Valores médios de deformação total $\left(D_{T}\right)$.

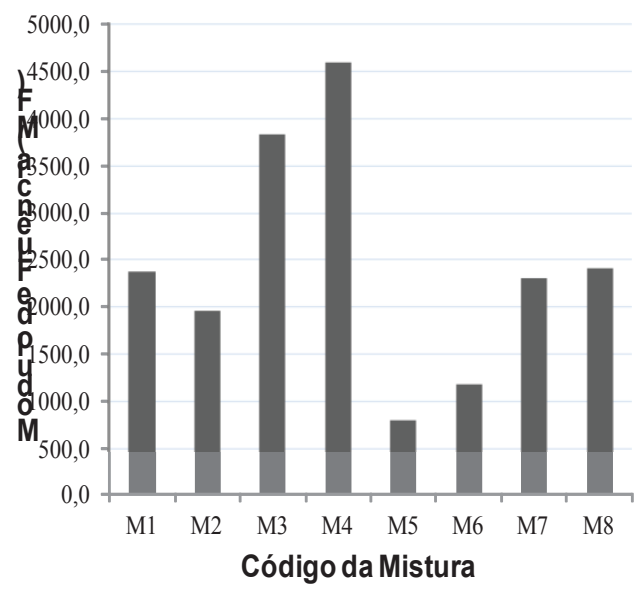

a) $40^{\circ} \mathrm{C}$



b) $50^{\circ} \mathrm{C}$

Figura 30 - Valores médios de módulo de fluência $\left(M_{F}\right)$.

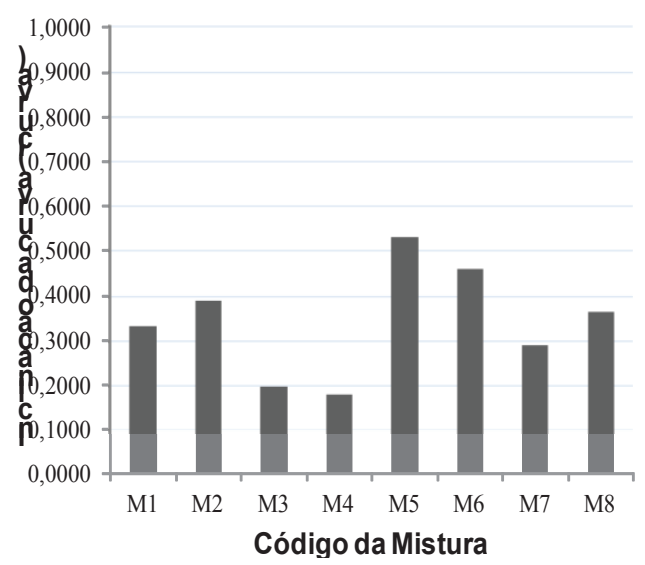

a) $40^{\circ} \mathrm{C}$

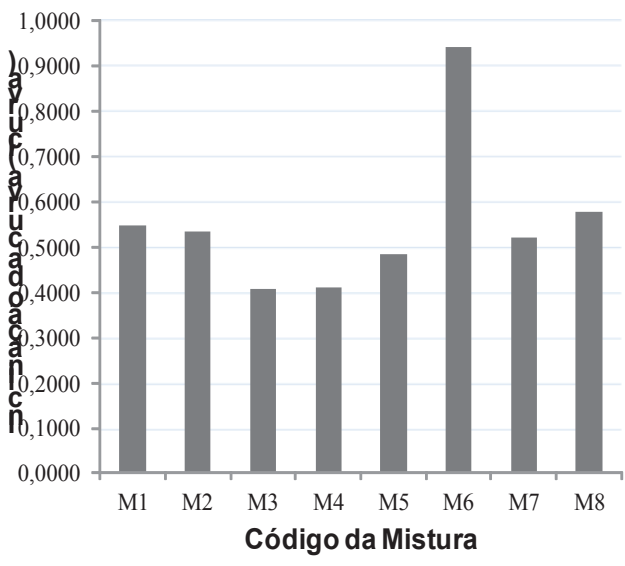

b) $50^{\circ} \mathrm{C}$

Figura 31 - Valores médios de inclinação da curva ( $\left.I_{\text {curva }}\right)$. 
No ensaio de creep dinâmico, confirma-se mais uma vez o conceito de relação inversa entre módulo de fluência e a deformação permanente. A mistura asfáltica M4 ensaiada à $40^{\circ} \mathrm{C}$ apresentou o maior módulo de fluência, enquanto o menor foi o da M5 na temperatura de $50^{\circ} \mathrm{C}$.

Foram observados valores mais altos para inclinações das curvas no creep dinâmico à $50^{\circ} \mathrm{C}$. A mistura asfáltica $\mathrm{M} 6$ ensaiada na temperatura mais alta, apresentou a maior $I_{\text {curva }}$, enquanto a menor foi da misturas asfáltica M4.

Em suma, baseado nos resultados apresentados as misturas asfálticas M3 e M4 ensaiadas na temperatura de $40^{\circ} \mathrm{C}$ destacaram-se por apresentarem os menores valores para a deformação total (bem próximos entre si) e por consequência os maiores módulos de fluência, além de alcançarem os menores valores de inclinação da curva de fluência. E a temperatura de ensaio foi decisiva no comportamento das misturas asfálticas.

\subsubsection{Análise dos efeitos isolados}

Para melhor compreensão dos resultados obtidos no ensaio de previsão de deformação permanente (creep dinâmico) são discutidos neste subitem a influência de cada condição experimental sobre o comportamento das misturas asfálticas, tomando por referência os parâmetros de ensaio.

\subsubsection{Volume de vazios}

Ao estudar os parâmetros de ensaio sob a ótica de variação do volume de vazios foi possível observar algumas peculiaridades no comportamento das misturas asfálticas. A deformação total aumentou, com a variação do volume de vazios de $4 \%$ para $7 \%$. Estas variações foram consideradas altas, o maior percentual de aumento observado foi de $420 \%$ para as misturas asfáltica composta de ligante convencional e cal. Tomando valores médios, o percentual de aumento da deformação permanente ao variar o volume de vaziosde $4 \%$ para $7 \%$, foi de $237 \%$. Outra constatação é a influência da temperatura nestes valores, ou seja, assim como a deformação permanente foi maior quanto maior foi o volume de vazios adotado, quanto maior a temperatura de ensaio maior a $\mathrm{D}_{\mathrm{T}}$. Isto é, uma mistura asfáltica com 
$4 \%$ de volume de vazios apresenta maior deformação no ensaio à $50^{\circ} \mathrm{C}$ do que à $40^{\circ} \mathrm{C}$.

No módulo de fluência, houve uma tendência de obter-se maiores valores para as misturas asfálticas moldadas à $4 \%$ de volume de vazios. No geral e em termos médios o $\mathrm{M}_{\mathrm{F}}$ diminui em $51 \%$ ao aumentar o volume de vazios para $7 \%$. $\mathrm{Na}$ menor temperatura de ensaio o decréscimo no $M_{F}$ foi de $48 \%$, enquanto na maior temperatura foi de $60 \%$.

O aumento do volume de vazios exerceu influência sobre a inclinação da curva, com exceção das misturas asfálticas com ligante modificado (sem adição de cal) no ensaio à $40^{\circ} \mathrm{C}$ e mistura convencional (sem adição de cal) no ensaio à $50^{\circ} \mathrm{C}$. Foi observado um aumento da $\mathrm{I}_{\text {curva }}$ ao aumentar-se o $\mathrm{V} v \%$. O percentual médio de acréscimo foi de $40 \%$, enquanto para as temperaturas $40^{\circ}$ e $50^{\circ} \mathrm{C}$ foram de 50 e $33 \%$ respectivamente. Pode-se concluir então que, misturas asfálticas com $7 \%$ de volume de vazios possuem maior velocidade de deformação se comparadas às de $4 \%$ de volume de vazios.

É apresentada a Tabela 22 com a finalidade de resumir o comportamento dos parâmetros de creep dinâmico quanto à variação do volume de vazios.

Tabela 22 - Resumo dos efeitos do aumento do volume de vazios de $4 \%$ para $7 \%$.

\begin{tabular}{lcc}
\hline Parâmetros & \multicolumn{2}{c}{$\begin{array}{c}\text { Aumento do volume de } \\
\text { vazios }\end{array}$} \\
& Efeito à $\mathbf{4 0} 0^{\circ} \mathbf{C}$ & Efeito à $50^{\circ} \mathbf{C}$ \\
\hline Deformação Total & aumenta & aumenta \\
Módulo de Fluência & diminui & diminui \\
Inclinação da curva & aumenta & aumenta \\
\hline
\end{tabular}

\subsubsection{Ligante asfáltico}

A variação do tipo de ligante asfáltico mostrou-se satisfatória do ponto de vista de se obter respostas evidentes quanto ao comportamento das misturas asfálticas à deformação permanente. Valkering et al., (1990) destacou o fato de o ensaio de creep dinâmico transmitir melhor os efeitos da adição do polímero SBS ao ligante asfáltico do que o creep estático. 
Quanto ao parâmetro deformação total, foi constatado que misturas asfálticas compostas pelo ligante asfáltico modificado $\left(\right.$ Stylink $\left.^{\circledR}\right)$ se deformaram bem menos que as compostas pelo ligante asfáltico CAP $50-70$. No ensaio à $40^{\circ} \mathrm{C}$ a redução da $D_{T}$ foi de $57 \%$ enquanto à $50^{\circ} \mathrm{C}$ foi de $77 \%$, no geral esta redução foi de $75 \%$. Uma possível explicação para este comportamento seria a de que os polímeros colaboram para que as misturas asfálticas tornem-se mais flexíveis e resistentes às deformações permanentes.

Os resultados de módulo de fluência se mostraram coerentes com os valores de deformação total. Pois os maiores $\mathrm{M}_{\mathrm{F}}$ foram alcançados pelas misturas com ligante asfáltico modificado, indicando uma maior resistência à deformação permanente para estas misturas betuminosas. Ao adicionar o polímero SBS à mistura asfáltica houve, em média, um ganho de $120 \%$ no valor do módulo de fluência. Na menor temperatura de ensaio o acréscimo foi de $108 \%$, enquanto na maior temperatura foi de $167 \%$.

Ao adicionar o polímero ao ligante asfáltico houve $30 \%$ de redução na inclinação da curva de fluência. No ensaio à $40^{\circ} \mathrm{C}$ o percentual de redução foi de $40 \%$ e à $50^{\circ} \mathrm{C}$ foi de $23 \%$.

De forma geral, pode-se afirmar que o polímero SBS beneficiou as misturas asfálticas quanto à resistência à deformação permanente. Com o intuito de sintetizar as constatações realizadas é apresentada a Tabela 23.

Tabela 23 - Resumo dos efeitos da adição de SBS ao ligante asfáltico.

\begin{tabular}{lcc}
\hline \multicolumn{1}{c}{ Parâmetros } & $\begin{array}{c}\text { Mistura } \\
\text { convencional }\end{array}$ & Mistura modificada \\
\hline Deformação Total & maior & menor \\
Módulo de Fluência & menor & maior \\
Inclinação da curva & menor & maior \\
\hline
\end{tabular}

\subsubsection{Adição de cal}

Neste subitem serão discutidos os efeitos da adição de cal hidratada às misturas betuminosas deste estudo. A influência da cal não ficou muito evidente no parâmetro deformação total. Em uma tentativa de se entender melhor o 
comportamento das misturas asfálticas os valores desta variável foram considerados separadamente e foram divididos em dois grupos: misturas asfáltica com CAP 50-70 + cal e misturas asfálticas CAP 50-70+ SBS + cal. As misturas asfálticas com ligante asfáltico convencional demonstraram uma sensibilidade pouco expressiva (cerca de $8 \%$ ) de redução da $\mathrm{D}_{\mathrm{T}}$ ao acrescentar a cal em sua composição.

A interação da cal com o ligante asfáltico SBS novamente demonstrou afetar o desempenho dessas misturas asfálticas, pois não demonstraram tendência sobre os valores de módulo de fluência. No entanto, as misturas asfálticas com CAP 50-70 apresentaram uma leve influência nos resultados ao adicionar a cal, o módulo aumentou em $13 \%$.

Não foi observada tendência nos valores obtidos para inclinação da curva de fluência. A Tabela 24 apresenta um resumo dessas observações.

Tabela 24 - Resumo dos efeitos da adição de cal nas misturas asfálticas.

\begin{tabular}{lcc}
\hline \multicolumn{1}{c}{ Parâmetros } & Com cal & Sem cal \\
\hline Deformação Total & menor * & maior * \\
Módulo de Fluência & maior * & menor * \\
Inclinação da curva & - & - \\
\hline
\end{tabular}

*Para misturas asfálticas com CAP 50-70

\subsection{RELAÇÕES ENTRE COMPACTAÇÃO E DEFORMAÇÃO PERMANENTE}

Nesta etapa da pesquisa, os parâmetros de compactação foram relacionados aos parâmetros de creep estático e dinâmico, com objetivo de identificar possíveis relações no comportamento destes índices. Estas relações entre as variáveis foram analisadas por meio de gráficos de dispersão, tendo como medida de qualidade o coeficiente de variação $R$ - quadrado da equação de regressão. Em relação ao ajuste da linha de tendência entre os valores, foram testadas as funções lineares e não lineares (logarítmica exponencial e polinominal).

Para todas as tentativas de relações foram testadas regressões lineares a fim de se tentar reproduzir de modo mais simples o comportamento. $\mathrm{Na}$ impossibilidade de obter bons $\mathrm{R}^{2}$, então nova tentativas de ajuste foram feitas para se obter um $\mathrm{R}^{2}$ de melhor ajuste, que poderia ser logarítmica, exponencial, 
polinomial ou linear. Apesar dessas tentativas, nem sempre se obteve $R^{2}$ de valores altos, mesmo com o ajuste de regressões não lineares. Por isso foi elaborada uma classificação considerando o $\mathrm{R}^{2}$ como um indicador de qualidade dos modelos, que é apresentada na Tabela 25.

Tabela 25 - Classificação proposta para as correlações.

\begin{tabular}{cc}
\hline $\mathbf{R}^{\mathbf{2}}$ & Classificação proposta: \\
\hline 0,00 a 0,19 & Correlação bem fraca \\
0,20 a 0,39 & Correlação fraca \\
0,40 a 0,69 & Correlação moderada \\
0,70 a 0,89 & Correlação forte \\
0,90 a 1,00 & Correlação muito forte \\
\hline
\end{tabular}

\subsubsection{Compactação versus creep estático}

Na Figura 32 são apresentadas as tentativa de relacionar a inclinação da curva de densificação do compactador giratório versus parâmetros de creep estático.
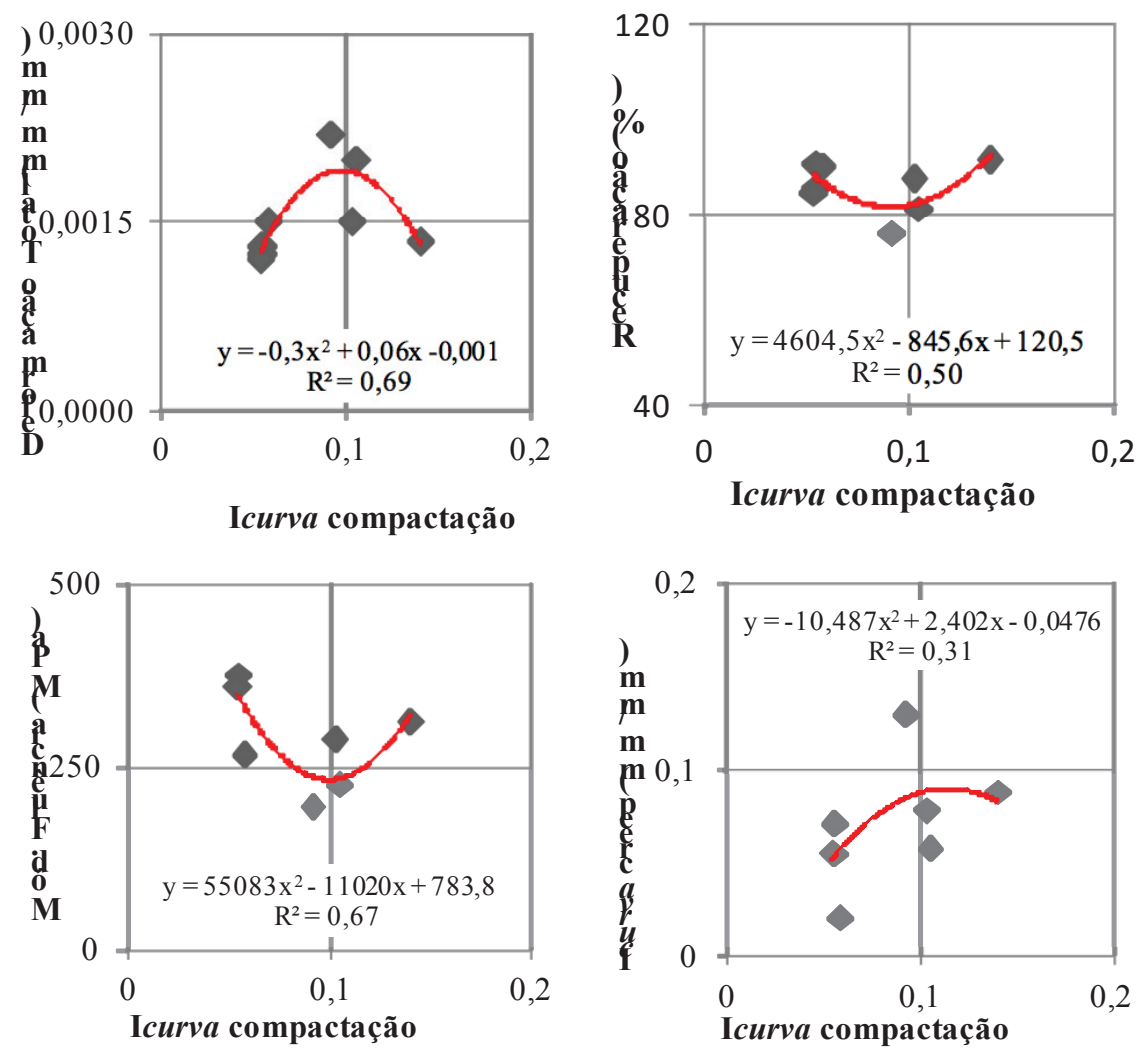

Figura 32 - I $I_{\text {curva }}$ de compactação versus parâmetros de creep estático. 
Para as variáveis $D_{T}, M_{F}$, recuperação e $I_{\text {curva }}$ de fluência, versus $I_{\text {curva }}$ de compactação foram ajustados os modelos de regressão polinomial de segunda ordem, caracterizando assim um comportamento não linear das relações. Ressaltase que as tentativas de equações de regressões não lineares visou buscar melhores ajustes, contudo dentre as relações testadas a melhor apresentou R-quadrado de 0,69 (moderada).

Das combinações realizadas, somente a $I_{\text {curva }}$ de fluência versus $I_{\text {curva }}$ de compactação foi considerada fraca. As demais foram consideradas moderadas, uma vez que o valor do R-quadrado ficou compreendido no intervalo de 0,50 a 0,69 . A relação deformação total versus inclinação da curva de compactação se destacou por apresentar o maior valor de $R^{2}(0,69)$. Apesar de não se tratar de uma relação que possa ser aplicada correntemente (em função das condições de contorno do experimento), pode-se apreciar que a deformação total pode estar relacionada com a facilidade de compactação.

$\mathrm{Na}$ tentativa de visualizar comportamentos com tendências mais claras de correlação $I_{\text {curva }}$ de compactação versus parâmetros do ensaio de creep estático, foram ajustadas regressões lineares para os resultados dos ensaios com misturas asfálticas, e a Figura 33 mostra os novos ajustes de regressões.

Apesar dos valores baixos de R-quadrado para o ajuste linear, é possível observar melhor a tendência de comportamento. $O$ parâmetro $I_{\text {curva }}$ indica a compactabilidade da mistura asfáltica, onde valores menores refletem misturas mais difíceis de compactar e valores maiores misturas que são mais fáceis de compactar. Entende-se que a dificuldade de compactação de uma mistura possa implicar problemas no esqueleto mineral, intertravamento.

Nesse sentido, ao se observar o conjunto de curvas da Figura 33, pode-se notar que com o aumento da $I_{\text {curva }}$ de compactação, a rigidez da mistura asfáltica, representada pelo $\mathrm{M}_{\mathrm{F}}$, tende a diminuir e concomitantemente observa-se uma tendência de aumento da velocidade de deformação, representada pelo $I_{\text {curva creep, }} \mathrm{e}$ da deformação $D_{T}$. É importante mencionar que a variável recuperação do creep estático não foi sensível à variação da $\mathrm{I}_{\text {curva }}$ de compactação. 
Essas tendências observadas não são razoáveis uma vez que o aumento da $I_{\text {curva }}$ de compactação deveria refletir em melhoras de propriedades mecânicas e não foi o que aconteceu. Deste modo, entende-se que as relações com $I_{\text {curva }}$ de compactação não são promissoras.

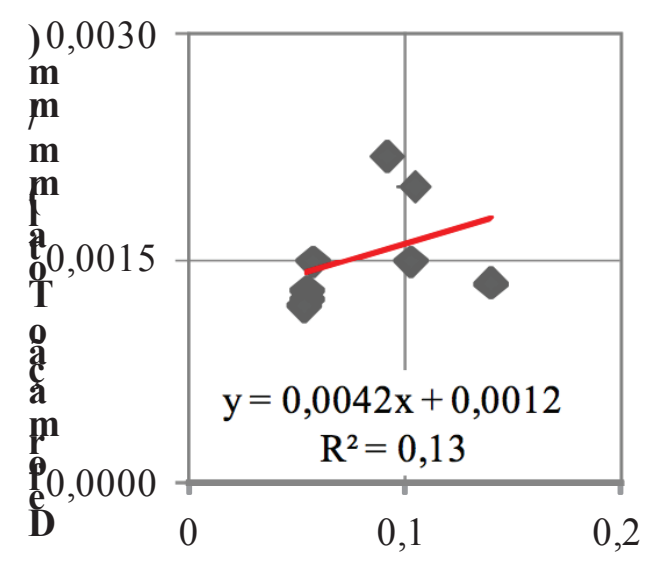

Icurva compactação

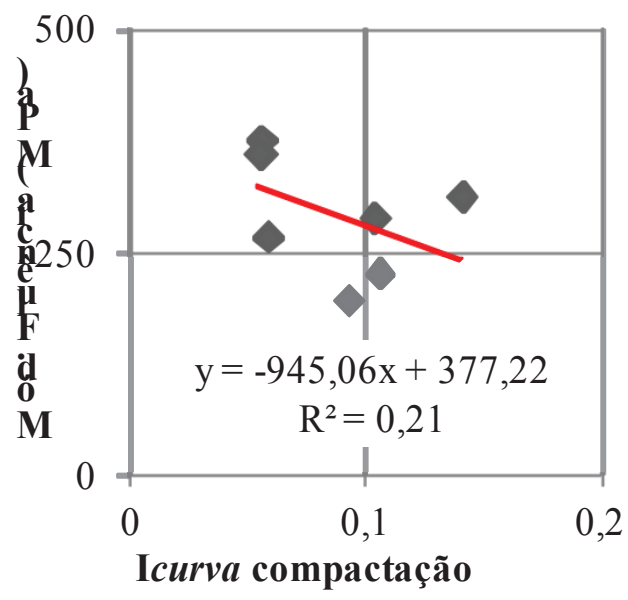

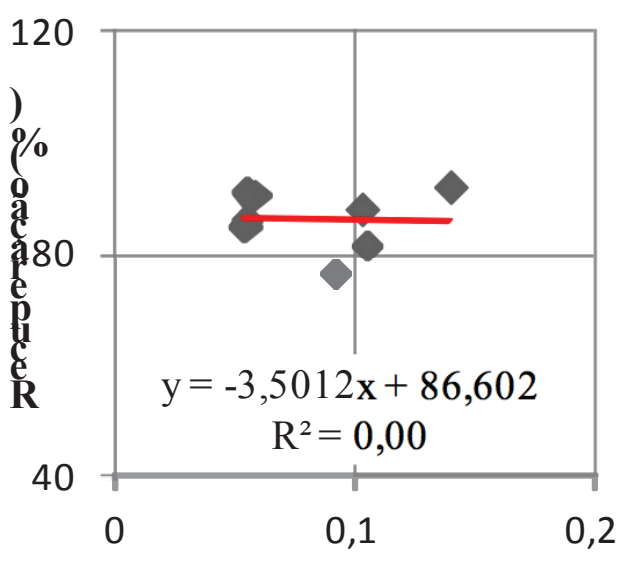

Icurva compactação

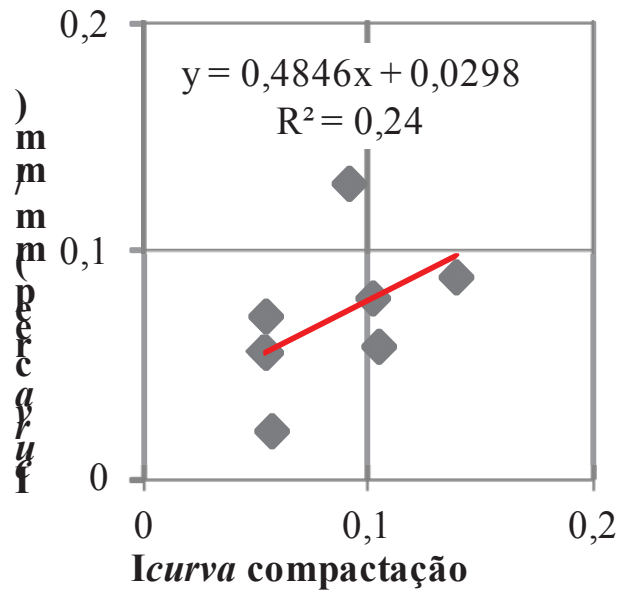

Figura 33 - Correlações entre $I_{\text {curva }}$ de compactação e parâmetros de creep estático.

A partir dos procedimentos de análise apresentados na Figura 33, adotou-se ajustes lineares em detrimento aos polinomiais (entre outros) porque a observação de tendências simplifica o processo de comparação das curvas das regressões com comportamento mecânico típico das misturas asfálticas. Por isso, similarmente, a Figura 34 mostra os ajustes lineares de regressões para a relação CDI versus parâmetros do creep estático.

O CDI indica a facilidade de compactação da mistura asfáltica pelos equipamentos no processo construtivo, sendo que valores baixos de CDI são 
desejáveis, pois indicam que a mistura asfáltica não necessita de altas energias para a compactação da camada de revestimento no campo. Com o aumento desse parâmetro, tem-se alguma dificuldade na densificação e, consequentemente, a necessidade de maiores energias.

Na tentativa de entender o efeito da variável CDI sobre os parâmetros de deformação permanente, partiu-se do principio que quanto menor é a aptidão da mistura a se compactar no campo menor poderá ser sua rigidez. Assim, observandose as tendências exibidas na Figura 34, tem-se que com o aumento do valor de CDI a mistura tende a exibir redução da rigidez $\left(\mathrm{M}_{\mathrm{F}}\right)$, o que implicou em aumento da

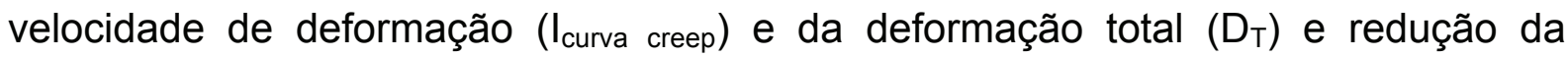
recuperação.
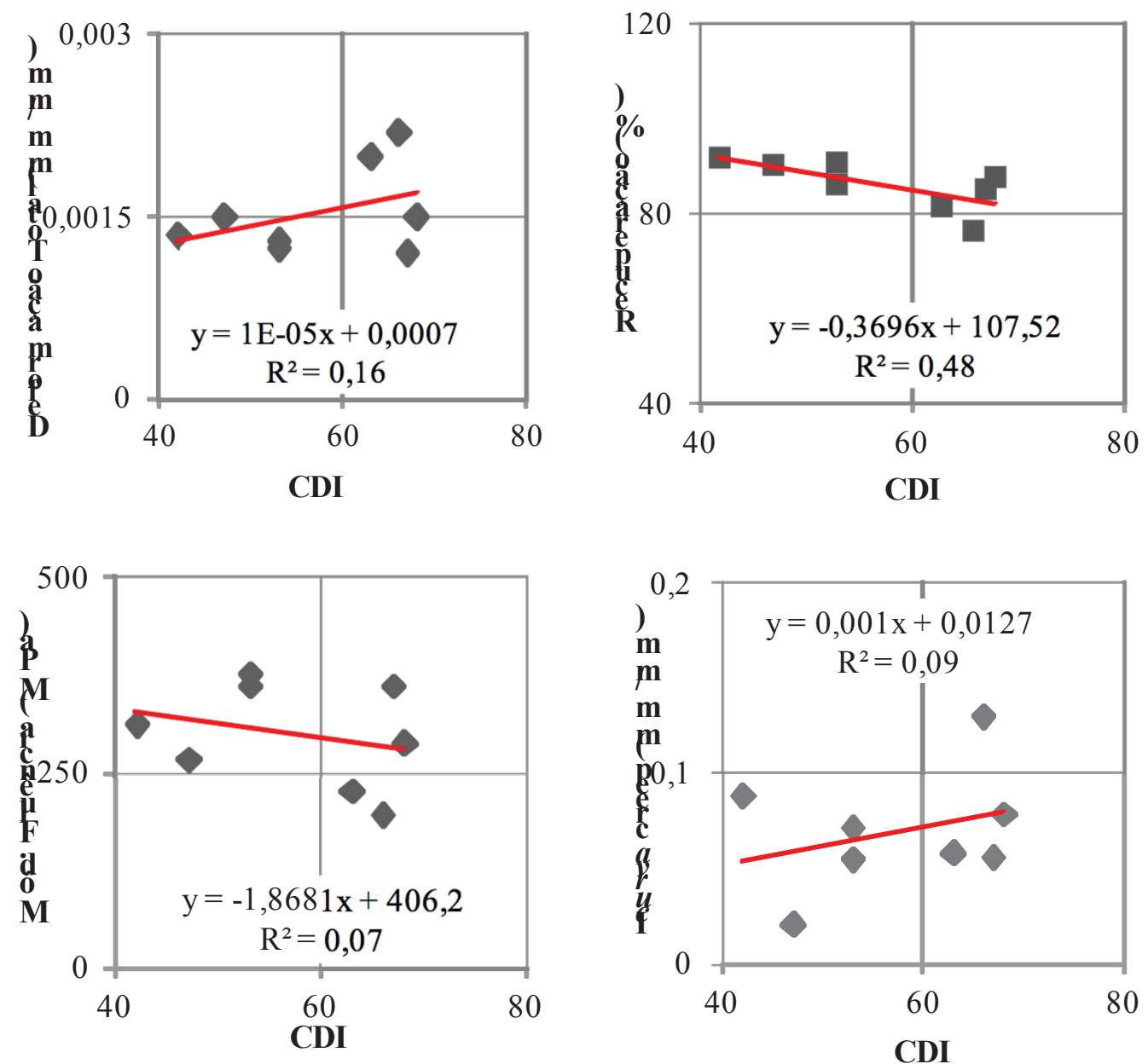

Figura 34 - Correlações entre CDI e parâmetros de creep estático. 
Na Figura 35 são apresentadas as correlações lineares entre o índice de compactação $\mathrm{TDI}_{\mathrm{m}}$ e parâmetros de creep estático. O TDI indica a suscetibilidade de sobrecompactação da mistura asfáltica pelo tráfego, sendo que valores altos de TDI indicam que a mistura asfáltica é mais estável e não deverá sofrer densificação com a abertura do tráfego; valores mais baixos desse parâmetro sinalizam misturas suscetíveis ao afundamento em trilha de rodas.

Observando-se a Figura 35, tem-se que os parâmetros parecem não ser influenciados pelo aumento da variável TDI, exceto para os ajustes com $M_{F}$ e I curva creep.
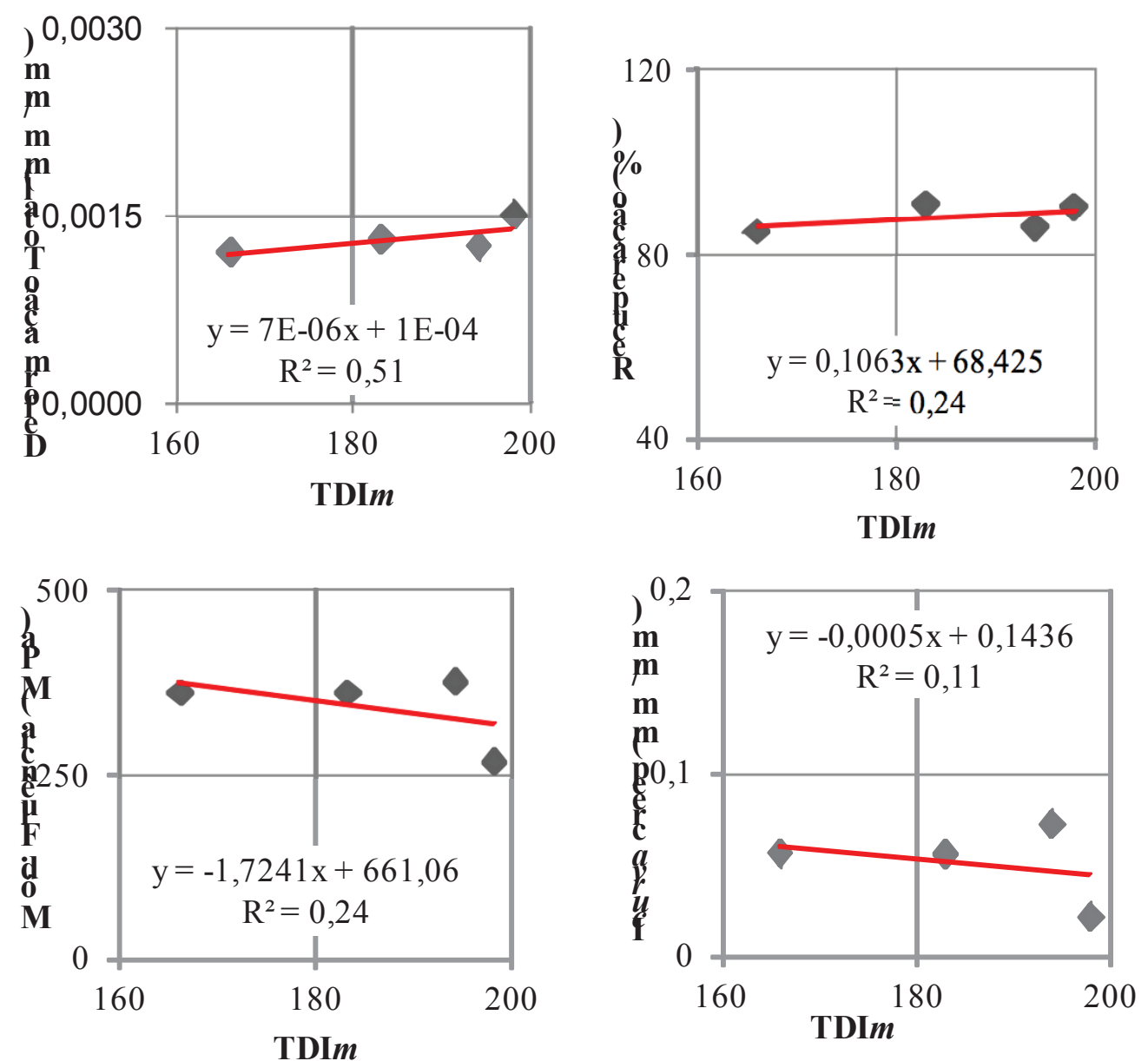

Figura 35 - Ajuste linear para correlações entre TDIm e parâmetros de creep estático.

Contudo, é importante destacar que a tendência delineada pelo ajuste não pode ser explicada pelo comportamento mecânico típico das misturas asfálticas, por exemplo, a mistura asfáltica apresentando valores altos de TDI (menor tendência de deformação permanente) não deveria exibir tendência de redução de $\mathrm{M}_{\mathrm{F}}$ e aumento 
de $D_{\mathrm{T}}$. Deste modo, por mais que TDI represente a aptidão da mistura asfáltica à sobrecompactação, acredita-se que esse índice não parece ser promissor no que se refere à estimativa de deformação permanente.

$\mathrm{Na}$ Figura 36 é ilustrada as tentativas de relações entre o índice de compactação locking point e parâmetros de creep estático. O locking point indica o número de giro em que ocorre o travamento do esqueleto pétreo da mistura asfáltica. A partir deste ponto o esforço adicional empregado na compactação provocaria degradação dos agregados minerais além de resultar em pouca densificação. Por isto, este parâmetro é indicado por alguns autores como uma opção de substituição ao $\mathrm{N}_{\text {projeto }}$.
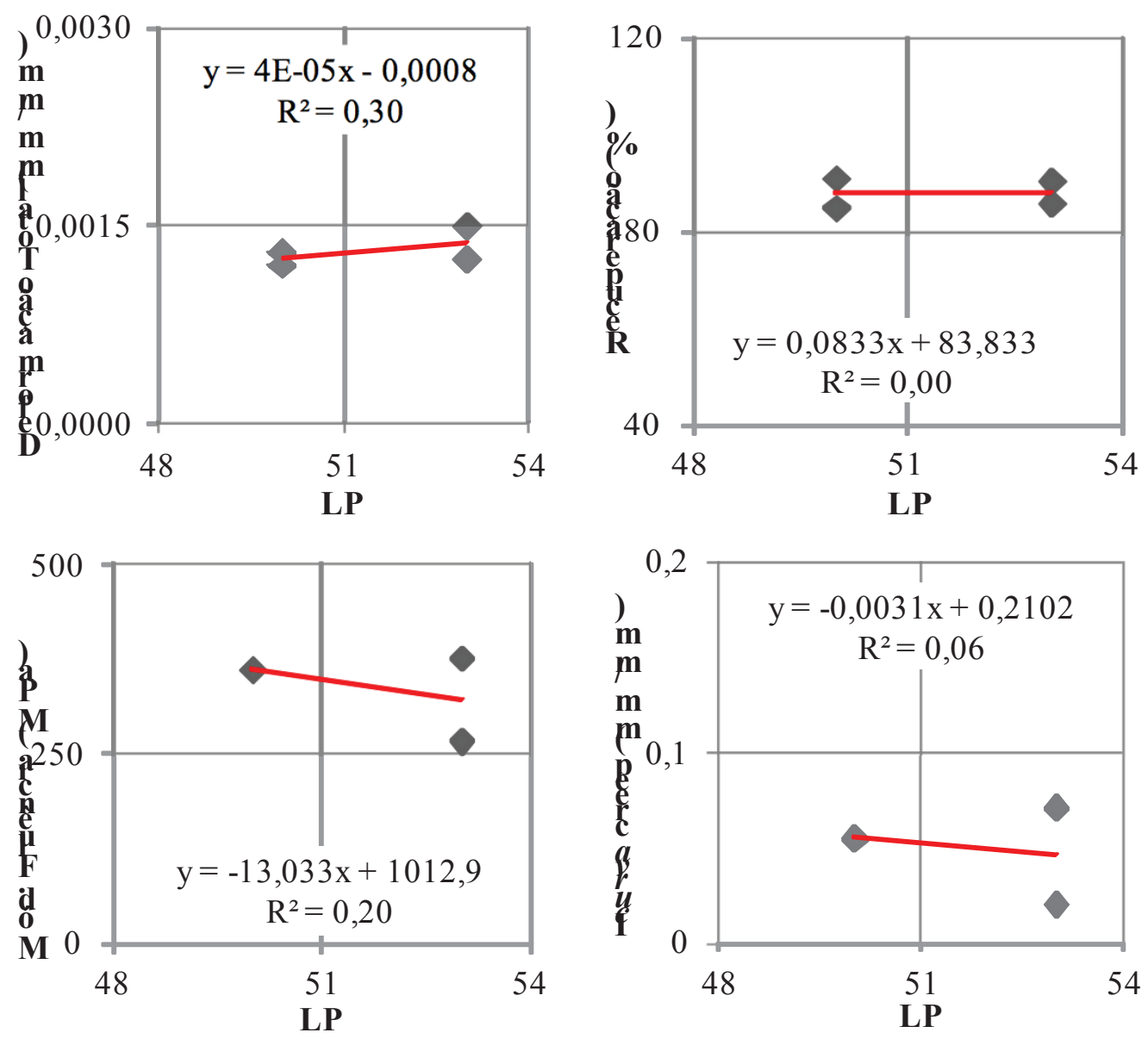

Figura 36 - Correlações entre LP e parâmetros de creep estático.

Ao observar a Figura 36, nota-se que as correlações não foram satisfatórias, uma vez que apresentaram relação fraca $\left(R^{2}\right.$ inferiores a 0,19$)$. Deste modo, para as condições deste experimento, o LP não demonstrou ser um parâmetro promissor ao 
ser relacionado com os parâmetros de creep estático. No entanto, ressalta-se que nesta pesquisa os resultados de LP delimitaram-se a uma pequena faixa de valores devido ao reduzido número de condições experimentais (CE). Para uma melhor verificação dos efeitos deste parâmetro em relação aos de creep estático, seria necessário trabalhar com diversidade de misturas asfálticas e, principalmente, variando-se suas curvas granulométricas.

\subsubsection{Compactação versus creep dinâmico}

Apesar dos ajustes não-lineares apresentarem maiores valores de $R^{2}$, a interpretação do comportamento dos parâmetros relacionados não ficou muito clara, por isso neste item foram apresentadas somente as tentativas de correlação com ajuste linear. A Figura 37 apresenta as correlações entre a $I_{\text {curva }}$ de densificação e parâmetros de creep dinâmico.
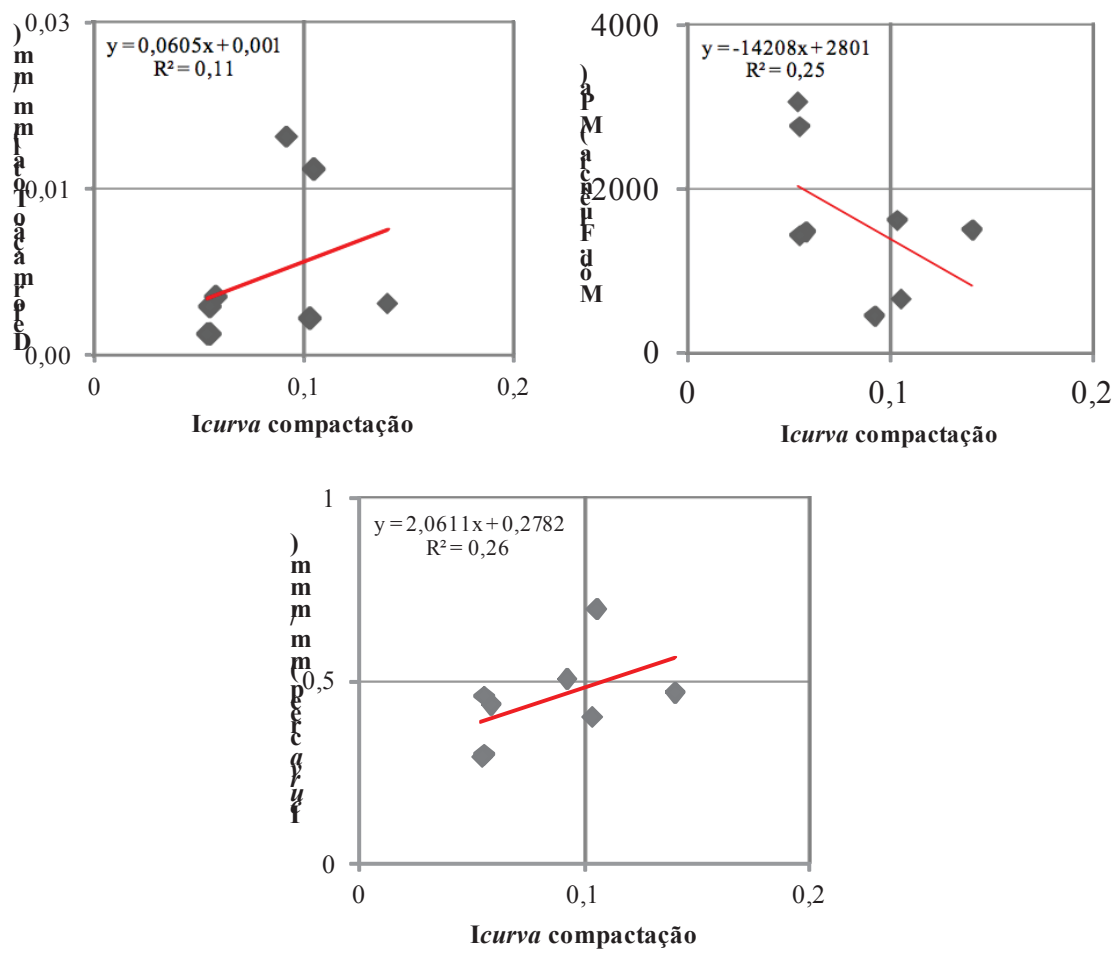

Figura 37 - Correlações entre $I_{\text {curva }}$ de compactação e parâmetros de creep dinâmico.

As variáveis $I_{\text {curva }}$ de compactação, $D_{\mathrm{T}}, M_{\mathrm{F}}$ e $I_{\text {curva }}$ de fluência relacionadas na Figura 34, apresentaram correlações consideradas fracas. A inclinação da curva de compactação que é um parâmetro relacionado à compactabilidade da mistura 
asfáltica não exerceu influência sobre os parâmetros de creep dinâmico. Mais uma vez (como observado nos resultados de creep estático) o parâmetro não é indicado para correlações, principalmente porque as tendências revelam comportamentos contrários ao comportamento típico das misturas asfálticas.

Na Figura 38 são apresentas as relações entre o parâmetro de compactação CDI e parâmetros do creep dinâmico.
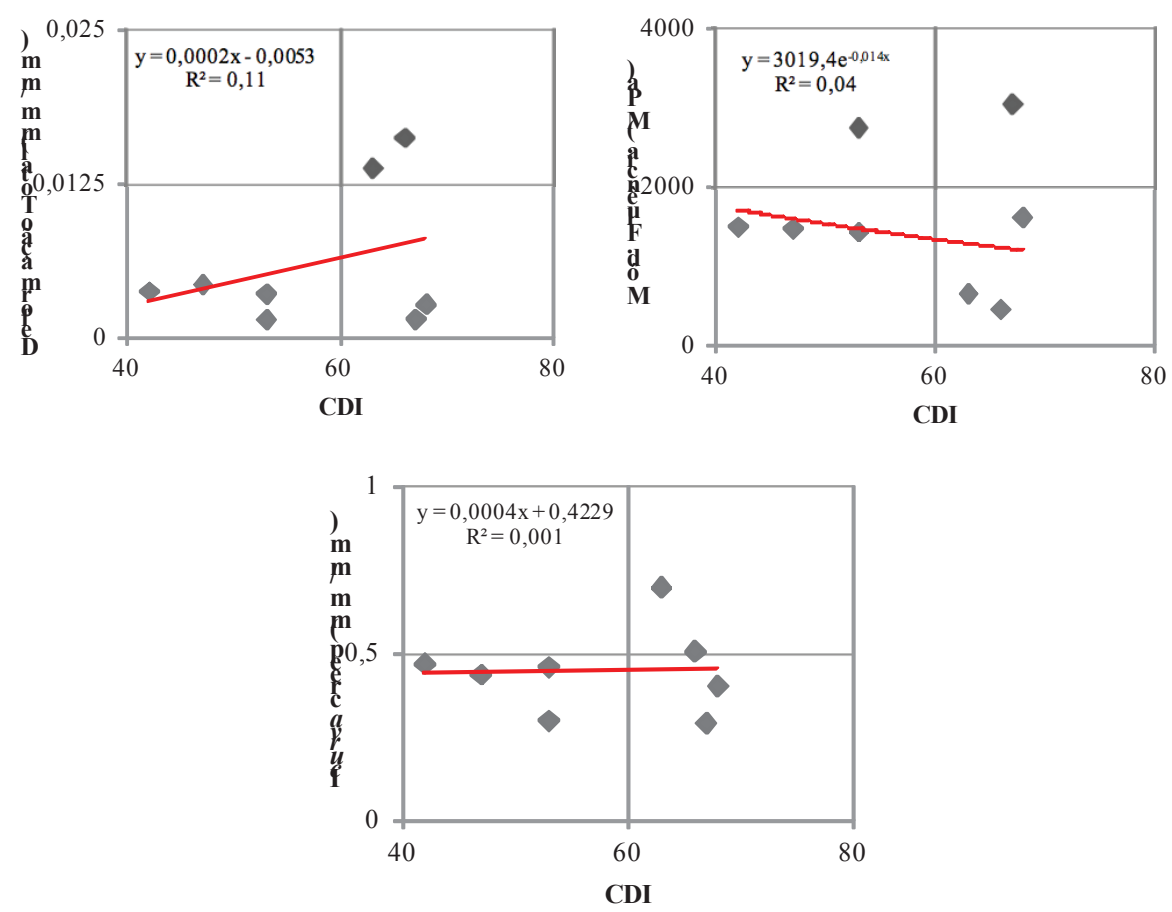

Figura 38 - Correlações entre CDI e creep dinâmico.

As combinações entre o índice de energia CDI e os parâmetros de creep dinâmico não foram muito promissoras. O CDI é um parâmetro que reflete a energia necessária na compactação durante a construção da via, valores baixos de CDI são desejáveis por indicarem uma maior facilidade de compactação da mistura asfáltica pelos compactadores.

Conforme o conceito proposto e discutido por Bahia et al., (1998), o aumento de CDI pode implicar em misturas menos resistentes, com isso, é possível também que a mistura passe a exibir maiores deformações. Ainda que $\mathrm{R}^{2}$ seja baixo, de certo modo, isso pode ser observado na Figura 38. Com relação à velocidade de

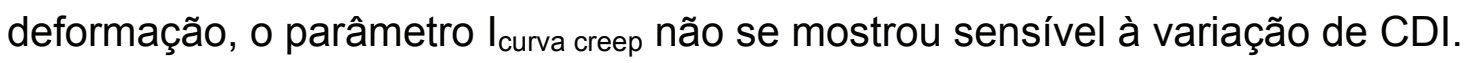


A Figura 39 apresenta as relações entre o parâmetro de compactação CDI e parâmetros do creep dinâmico.
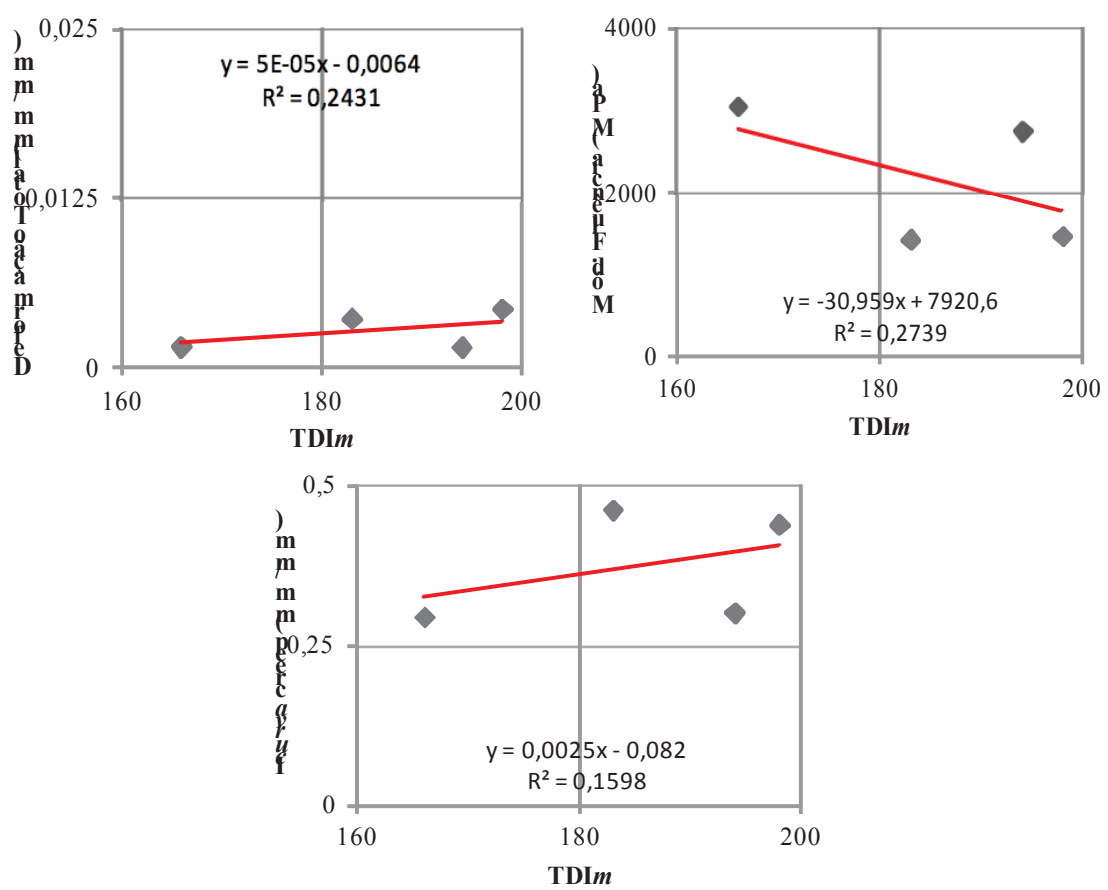

Figura 39 - Correlações entre TDIm e de creep dinâmico.

As variáveis $D_{T}, M_{F}, I_{\text {curva }}$ de fluência e TDI $I_{m}$ correlacionadas, não apresentaram um bom ajuste da linha de tendência, indicando não haver sensibilidabe entre estes parâmetros. O TDI dá indícios da estabilização da mistura asfáltica quando solicitada pelas cargas de tráfego, valores altos de TDI indicaria maior resistência a formação de trilhas de roda.

Novamente, a tendência delineada pelo ajuste não pode ser explicada pelo comportamento mecânico típico das misturas asfálticas, porque com o aumento de TDI não implicou menor tendência de deformação permanente, ao contrário, com o aumento de TDI houve redução de $\mathrm{M}_{\mathrm{F}}$ e aumento de $\mathrm{D}_{\mathrm{T}}$.

A Figura 40 apresenta as relações entre o parâmetro de densificação LP e parâmetros do creep dinâmico. As tentativas de correlações entre o locking point e os parâmetros de creep dinâmico foram muito fracas (como observado nas com creep estático), onde o valor de $\mathrm{R}^{2}$ chegou muito próximo de zero. $\mathrm{O}$ esforço de se correlacionar um parâmetro de compactação, que indica o ponto de travamento do esqueleto pétreo da mista asfáltica, com os parâmetros de ensaio de deformação 
permanente, não foram bem sucedidos, devido às reduzidas condicões de contorno do experimento.
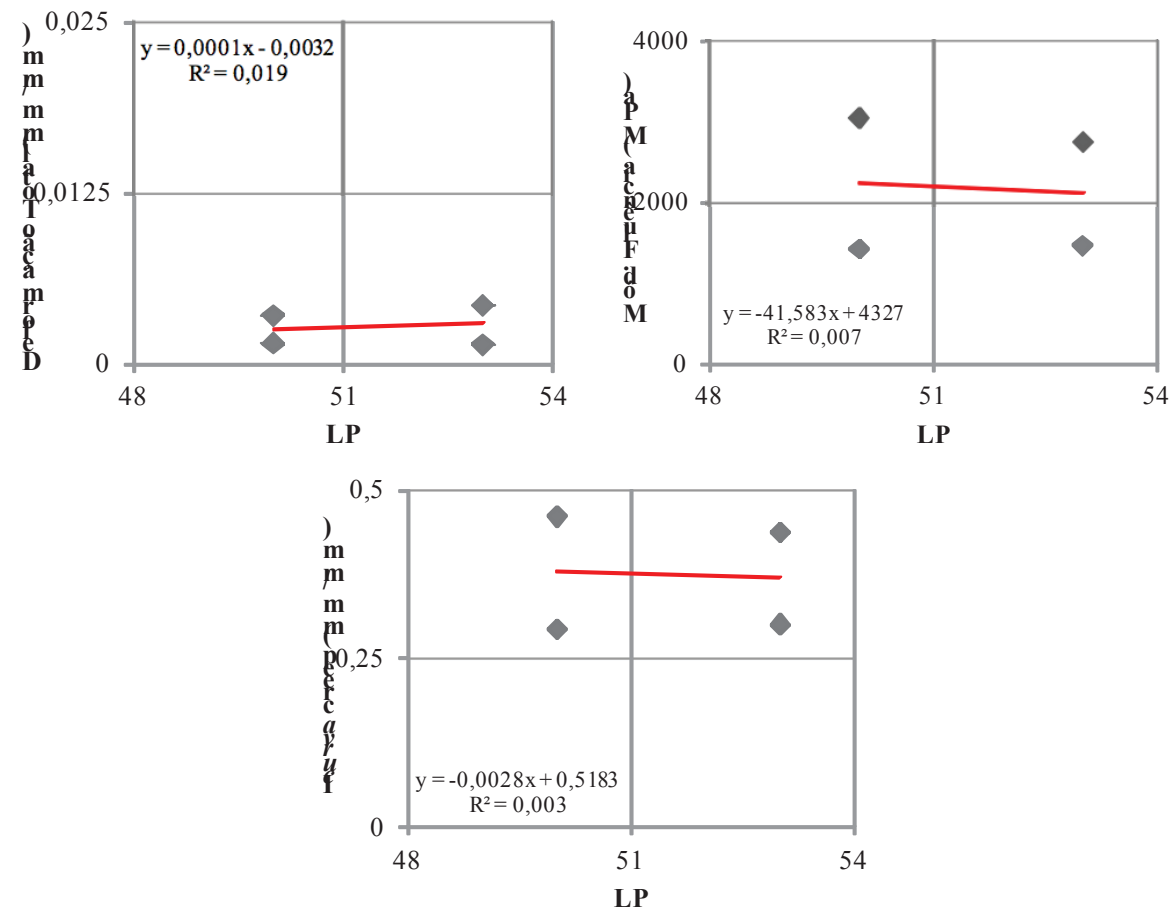

Figura 40 - Correlações entre LP e de creep dinâmico.

No geral, os parâmetros do creep dinâmico não demostraram ser sensíveis aos parâmetros de compactação, uma vez que não foram identificados padrões de comportamento. 
CÁPITULO 6

\section{CONCLUSÕES E SUGESTÕES}

\subsection{CONCLUSÕES}

Nesta pesquisa foram avaliados 8 tipos de misturas asfálticas, variando-se $o$ volume de vazios, o tipo de asfalto e a presença de aditivo. Estes fatores experimentais foram adotados com o intuito de entender o comportamento das misturas asfálticas quanto à compactação e à deformação permanente e posteriormente estudar a relação entre características de compactação e de deformação permanente.

Vale ressaltar que os resultados obtidos são limitados às condições de contorno desta pesquisa. Alguns parâmetros de compactação foram obtidos somente para misturas asfálticas com $V v=4 \%$ e não foi possível fazer um comparativo em relação às misturas com $\mathrm{Vv}=7 \%$. $E$ ainda, as condições experimentais podem ter sido insuficientes para uma boa relação entre parâmetros.

Diante do exposto, à luz dos ensaios de compactação giratória foi possível concluir que as misturas asfálticas com $\mathrm{V} v=4 \%$ apresentaram menor trabalhabilidade que as de $7 \%$ e que a cal modifica algumas características das curvas de compactação, indicando uma maior trabalhabilidade (baseado nos valores de CDI) e maior resistência à densificação em serviço.

No que se refere à deformação permanente, observou-se que misturas asfálticas com $V_{v}=4 \%$ apresentaram menor acúmulo de deformação permanente e maiores módulos de fluência que as com $V v=7 \%$. As misturas asfálticas modificadas com SBS também apresentaram melhor resistência à deformação permanente do que as misturas convencionais, mas esse efeito ficou evidente somente em ensaios de creep dinâmico.

As relações entre parâmetros de compactação e deformação permanente não demonstraram resultados promissores. As correlações apresentaram baixos valores de $R^{2}$ e não exibiram um padrão de comportamento condizente com os típicos de misturas asfálticas, à exceção das relações do creep estático: 
i) $\quad$ CDI versus recuperação $\left(R^{2}=0,48\right)$;

ii) $\quad \operatorname{TDI}_{\mathrm{m}}$ versus deformação total $\left(\mathrm{R}^{2}=0,51\right)$.

Apesar dos resultados não serem animadores, acredita-se que não se deve descartar a possibilidade de correlacionar parâmetros de compactação com os de deformação permanente. Acredita-se também que respostas promissoras podem estar relacionadas a um programa experimental maior que considere misturas asfálticas de variados composições granulométricas e tamanhos máximos nominais.

\subsection{SUGESTÕES À TRABALHOS FUTUROS}

- Utilização de um simulador de tráfego do tipo Laboratoire Central des Ponts et Chaussées (LCPC) para a determinação de parâmetros de deformação permanente, a fim de propor relações com parâmetros de compactacao e de comparar com os resultados obtidos em ensaios de creep estático e dinâmico.

- Execução de ensaio de creep estático e dinâmico até a ruptura dos corpos de prova, com a finalidade de observar o estágio terciário de fluência e obter os parâmetros flow time (FT) e flow number (FN). Sugere-se que estes parâmetros sejam confrontados com os parâmetros de compactação giratória Superpave ${ }^{\circledR}$. 


\section{REFERÊNCIAS BIBLIOGRÁFICAS}

Anderson, R. M.; Turner, P. A.; Peterson, R. L.; Mallick, R. B.; 2002, Relationship of superpave gyratory compaction properties to HMA rutting behavior, National Cooperative Highway Research Program - NCHRP Report 478, Washington, D. C., EUA.

Anguas, P.G.; López, J.A.G.; Alamilla, H.D.; 2003. Algunos aspectos de la densificación de mezclas asfálticas con el compactador giratório. Publicação técnica, $\mathrm{n}^{\circ}$ 228. Instituto Mexicano de transportes. ISSN: 0188-7297.

Asphalt Institute, 1989, The Asphalt Handbook. Edição 1989. Asphalt Institute (MS-4). Lexington, KY, EUA.

Bahia, H. U.; Friemel ,T. P.; Peterson, P.A.; Russell, J. S.; and Poehnelt, B.,1998. Optimization of Constructibility and Resistance to Traffic: A New Design Approach for HMA Using the Superpave Compactor. Asphalt Paving Technology, Journal of the Association of Asphalt Paving Technologists.

Bardini, V. S. S; Klinsky, L. M.G.; Fernandes Jr, J. L., 2010. A importância do fíler para o bom desempenho de misturas asfálticas. Revista Minerva. Disponível em: < http://www.fipai.org.br >

Berger, E., Huege, F., 2006. The use of hydrated lime in hot mix asphalt. Disponível em : $<w w w$.internationallime.org $>$. Acesso em 02/2014.

Bernucci, L. B.; Motta, L. M. G.; Ceratti. J. A. P.; Soares. J. B., 2007. Pavimentação asfáltica: Formação básica para engenheiros. Rio de Janeiro: PETROBRAS: ABEDA.

Chen, J., Lin, C., Stein, E. and Hothan, J. (2004). "Development of a Mechanist- Empirical Model to Characterize Rutting in Flexible Pavements". Journal of Transportation Engineering, American Society of Civil Engineers.

Coelho,V.; Sória, M.H.A.; 1994. Influência de temperaturas dos corpos de prova nos resultados do ensaio Marshall. In: REUNIÃO ANUAL DE PAVIMENTAÇÃO, 28 ${ }^{\mathrm{a}}$, Belo Horizonte-MG, Associação Brasileira de Pavimentação-ABPv, Anais. v. 1, p. 317 -348.

Dantas, G. H. S., 2012. Estudo do emprego do Compactador Giratório Superpave na compactação de um solo argiloso. Dissertação (mestrado) - Escola de Engenharia de São Carlos, Universidade de São Paulo. São Carlos, SP.

Delage, K. P., 2000, The Effect of Fine Aggregate Angularity on Hot Mixture Asphalt Performance. Tese de M.Sc., Department of Civil and Environmental Engineering - University of WisconsinMadison. Madison, Wisconsin, EUA. Novembro.

DNER (1994). Método de ensaio DNER - ME 78/94. Agregado graúdo - adesividade a ligante betuminoso. Departamento Nacional de Estradas e Rodagem. Rio de Janeiro.

DNER (1994). Método de ensaio DNER - ME 84/95. Agregado miúdo - adesividade a ligante betuminoso. Departamento Nacional de Estradas e Rodagem. Rio de Janeiro.

Dessouky, S.; Masad, E.; Asce, A. M. et al., 2002, Prediction of hot-mix asphalt stability using the Superpave gyratory compactor, Journal of materials in civil engineering, Vol. 16, EUA.

Furlan, A.P., 2006. Considerações acerca da adesão e da suscetibilidade à umidade de misturas asfálticas densas à luz de algumas propriedades mecânicas. Tese (Doutorado) - Escola de Engenharia de São Carlos, Universidade de São Paulo. São Carlos, SP.

Foretti, A.C., 1999. Estudo de misturas preparadas com asfalto convencional e asfalto modificado com polímeros. Dissertação de M. Sc., Escola de Engenharia de São Carlos - Universidade de São Paulo, São Carlos, SP.

Gouveia, L. T., 2006, Contribuições ao estudo da influência de propriedades de agregados no comportamento de misturas asfálticas densas. Tese de D.Sc., Universidade de São Paulo EESC, São Carlos, SP, Brasil.

Harman, T., Bukowski, J. R., Moutier, F., Huber, G. e MCG Sennis, R., 2002. History and Future Challenges of Gyratory Compaction - 1939 to 2001. Transportation Research Record 1789.

Huber, G., 1996. Development of the Superpave Gyratory Compactor. Heritage Research. Indianapolis, Indiana. 
Huber, G.A., 1999. Methods to achieve rut-resistant durable pavements. Synthesis of Highway Practice 274. National Cooperative Highway Research Program. Transportation Research Board. Washington, D.C. Dissertação (Mestrado). Faculdade de Engenharia, Universidade do Porto.

Leiva, F., West, R. C., 2006. Analysis of hot mix asphalt lab compactability using lab compaction parameters and mix characteristics. Transportation Research Record: Journal of the Transportation Research Board,No. 2057, Transportation Research Board of the National Academies, Washington, D.C., 2008, pp. 89-98.

Leiva-Villacorta, F., 2007. Relationships between laboratory measured characteristics of HMA and field compactability. Dissertação (Mestrado). Faculty of Auburn University. Alabama, E.U.A.

Little, D. N., Epps, J. A., The benefits of hydrated lime in hot mix asphalt.National Lime Association, The Versatile Chemical, 2001.

Lopes, M.M.; Linhares, M.; Vasconcelos, K.L.; Bernucci, L.L.B.; 2011. Estudo do processo de densificação e da deformação permanente de misturas asfálticas. ANPET. Escola Politécnica da Universidade de São Paulo, São Paulo, SP.

Marques, G.L.O., 2004. Utilização do módulo de resiliência como critério de dosagem de mistura asfáltica, efeito da compactação por impacto e giratório. Tese (Doutorado) Universidade Federal do Rio de Janeiro, COPPE/UFRJ, Rio de Janeiro, RJ.

Micaelo, R. A. L. B., 2008. Compactação de misturas betuminosas: ensaios de compactação e modelagem numérica. Dissertação (Mestrado). Faculdade de Engenharia, Universidade do Porto. Porto, Portugal.

Mohamed, E.H.H.; YUE. Z., 1994. Criteria for evaluation of rutting potential based on repetitive uniaxial compression test. Transportation Research Record 1454, p.7481. Washington, D.C.

Mahmoud, A.F.F. e BAHIA, H.; 2004. Using the gyratory compactor to measure mechanical stability of asphalt mixtures. Wisconsin Highway Research Program, Project Number 0092-01-02.

Motta, L. M. G., Tonial, I. , Leite, L. M., et al., 1996. Princípios do projeto e Análise SUPERPAVE de misturas asfálticas. Tradução comentada, Instituto Brasileiro do Petróleo - IBP.

Moura, E. D., 2010. Estudo de deformação permanente em trilha de roda de misturas asfálticas em pista e em laboratório. Tese de doutorado, Escola Politécnica da Universidade de São Paulo. São Paulo, SP.

Mugayar, A.N., 2004. Avaliação dos efeitos do tipo de asfalto e da distribuição granulométrica do agregado nas fluências estática e dinâmica de misturas asfálticas densas. Dissertação de Mestrado, Escola de Engenharia de São Carlos - Universidade de São Paulo, São Carlos, SP.

Nascimento, L. A. H., 2008. Nova abordagem da dosagem de misturas asfálticas densas com uso do compactador giratório e foco na deformação permanente. Dissertação de Mestrado, COPPE/UFRJ, Rio de Janeiro, RJ, 2008.

Neto, B. C., 2004. Avaliação do aproveitamento de areia de fundição como agregado em misturas asfálticas densas. Tese de Dr. Sc., Escola de Engenharia de São Carlos - Universidade de São Paulo, São Carlos, SP.

Onofre, F. C., Bessa, I.S., Castelo Branco, V.T.F., Soares, J.B.; 2011. Correlação entre variáveis de densificação do compactador giratório e resistência à deformação permanente de misturas asfálticas convencionais e com resíduos. Manuscrito recebido em 27/05/2010 e aprovado para publicação em 6/4/2011. Este artigo é parte de TRANSPORTES v. 19, n.1, 2011. P. 13-22. ISSN: 2237-1346.

Pine, W. J., 1997, Superpave Gyratory Compaction and the Ndesign Table. Relatório Illinois Department of Transportation. Illinois, EUA.

Prowell, B. D.; Brown, E. R., 2007, Superpave mix design: verifying gyration levels in the Ndesign table, National Cooperative Highway Research Program - NCHRP Report 573, Washington, D. C., EUA.

Santanna-Greco, J. A., 2004. Avaliação da influência de alguns fatores nas propriedade mecânicas de misturas asfálticas densas, à luz da técnica de planejamento e análise de experimentos fatoriais fracionários assimétricos. Tese de Dr. Sc., Escola de Engenharia de São Carlos Universidade de São Paulo, São Carlos, SP.

Sebaaly, P. E., 2006. The benefits of hydrated lime in hot mix asphalt.National Lime Association, The Versatile Chemical.

Souza, A. S., 2008. Avaliação da capacidade de escoamento da água em misturas asfáltica drenante: Proposta de ensaio de laboratório. Dissertação de M. Sc., Universidade Federal do Rio de Janeiro, Rio de Janeiro, RJ. 
Van de Loo, P. J., 1974. Creep testing, a simple tool to judge asphalt mix stability. Association of Asphalt Paving Technologists (AAPT), Proceedings, v. 43, p. 253-284.

Vavrik, W. R., and S. H. Carpenter. "Calculating Air Voids at Specified Number of Gyrations in Superpave Gyratory Compactor," Transportation Research Record 1630, Transportation Research Board, Washington, D. C., EUA.

Witczak, M. W., 2007, Specification criteria for simple performance tests for Rutting; Volume I: Dynamic Modulus $\left(\mathrm{E}^{*}\right)$; Volume II: Flow Number and Flow Time, National Cooperative Highway Research Program - NCHRP Report 580, Washington, D. C., EUA.

Witczak, M. W., Kaloush, K., Pellinem, T., El - Basyouny, M., Von Quintus, H., 2002, Simple performance test for superpave mix design - NCHRP Report 465, Washington, D. C., EUA.

Roberts, F.L., Kandhal, P.S., Brown, E.R., Lee, D-Y. e Kennedy, T.W. (1996). Hot Mix Asphalt Materials, Mixture, Design, and Construction. Segunda Edição, NAPA Education Foundation, Lanham, Maryland. 
ANEXO I - Valores das inclinações das curvas de compactação

\begin{tabular}{cc}
\hline $\mathbf{C P}$ & $\mathbf{I}_{\text {curva }}$ compactação \\
\hline 1 & 0,057 \\
2 & 0,059 \\
3 & 0,054 \\
4 & 0,056 \\
5 & 0,054 \\
6 & 0,055 \\
7 & 0,054 \\
8 & 0,054 \\
9 & 0,091 \\
10 & 0,093 \\
11 & 0,103 \\
12 & 0,107 \\
13 & 0,104 \\
14 & 0,101 \\
15 & 0,139 \\
16 & 0,141 \\
\hline
\end{tabular}


ANEXO II - Valores de LP das misturas asfálticas

\begin{tabular}{ccccc}
\hline \multicolumn{5}{c}{ Locking Point } \\
\multicolumn{5}{c}{ V $=\mathbf{4} \%$} \\
CP & Pine & Vv\%inicial & Vv\% & Vv\%final \\
\hline 1 & 54 & 19,8 & 5,3 & 3,6 \\
2 & 49 & 19,7 & 5,7 & 3,5 \\
3 & 49 & 20,2 & 5,9 & 3,8 \\
4 & 54 & 20,2 & 5,5 & 3,8 \\
5 & 56 & 20,2 & 5,4 & 3,7 \\
6 & 57 & 20,6 & 5,5 & 3,9 \\
7 & 51 & 19,9 & 5,9 & 4,0 \\
8 & 47 & 19,8 & 6,3 & 4,2 \\
9 & 52 & 19,7 & 6,0 & 4,1 \\
10 & 54 & 20,0 & 6,1 & 4,2 \\
11 & 51 & 20,1 & 6,3 & 4,3 \\
12 & 46 & 20,4 & 6,4 & 4,0 \\
13 & 54 & 20,3 & 5,8 & 4,1 \\
14 & 51 & 20,1 & 5,6 & 3,7 \\
15 & 55 & 19,8 & 5,0 & 3,4 \\
16 & 51 & 20,5 & 6,0 & 4,2 \\
\hline
\end{tabular}


ANEXO III - Valores de CDI e TDI ${ }_{m}$ das misturas asfálticas

\begin{tabular}{ccc}
\hline CP & CDI & TDIm \\
\hline 1 & 40 & 211 \\
2 & 44 & 203 \\
3 & 54 & 187 \\
4 & 50 & 191 \\
5 & 48 & 192 \\
6 & 47 & 188 \\
7 & 56 & 171 \\
8 & 60 & 180 \\
9 & 55 & 182 \\
10 & 46 & 205 \\
11 & 56 & 194 \\
12 & 55 & 195 \\
13 & 61 & 172 \\
14 & 64 & 176 \\
15 & 73 & 157 \\
16 & 72 & 160 \\
\hline
\end{tabular}


ANEXO IV - Valores do ensaio creep estático na temperatura de $40^{\circ} \mathrm{C}$

\begin{tabular}{ccccc}
\hline \multicolumn{5}{c}{ Estático $\mathbf{0 , 4} \mathbf{4 0}{ }^{\circ} \mathbf{C}$} \\
CP & Def. Total & Recup (\%) & MF & I \\
\hline 1 & 0,0014 & 96 & 266,58 & 0,0110 \\
2 & 0,0018 & 79 & 231,87 & 0,0225 \\
3 & 0,0008 & 100 & 484,16 & 0,1365 \\
4 & 0,0007 & 100 & 559,25 & 0,0263 \\
5 & 0,0008 & 172 & 462,81 & 0,1146 \\
6 & 0,0007 & 215 & 571,52 & 0,1098 \\
7 & 0,0009 & 147 & 418,49 & 0,0175 \\
8 & 0,0008 & 175 & 496,03 & 0,1387 \\
9 & 0,0016 & 105 & 249,86 & 0,0651 \\
10 & 0,0015 & 126 & 268,95 & 0,1058 \\
11 & 0,0017 & 100 & 273,33 & 0,0790 \\
12 & 0,0012 & 100 & 336,64 & 0,0916 \\
13 & 0,0013 & 100 & 300,82 & 0,1389 \\
14 & 0,0009 & 100 & 440,69 & 0,1440 \\
15 & 0,0011 & 100 & 371,59 & 0,1276 \\
16 & 0,0010 & 100 & 410,70 & 0,1641 \\
\hline
\end{tabular}


ANEXO V - Valores do ensaio creep estático na temperatura de $50{ }^{\circ} \mathrm{C}$

\begin{tabular}{ccccc}
\hline \multicolumn{5}{c}{ Estático $\mathbf{0 , 4 5 0} \mathbf{~} \mathbf{C}$} \\
CP & Def. Total & Recup (\%) & MF & Icurva \\
\hline 1 & 0,0018 & 89 & 217,22 & 0,0180 \\
2 & 0,0011 & 100 & 355,72 & 0,0327 \\
3 & 0,0019 & 87 & 204,47 & 0,0378 \\
4 & 0,0020 & 77 & 196,47 & 0,0201 \\
5 & 0,0016 & 67 & 250,50 & 0,0342 \\
6 & 0,0018 & 73 & 220,69 & 0,0278 \\
7 & 0,0013 & 75 & 295,90 & 0,0300 \\
8 & 0,0017 & 75 & 234,83 & 0,0378 \\
9 & 0,0029 & 53 & 133,96 & 0,1746 \\
10 & 0,0026 & 63 & 148,59 & 0,0313 \\
11 & 0,0018 & 81 & 217,98 & 0,0309 \\
12 & 0,0020 & 71 & 196,50 & 0,0014 \\
13 & 0,0016 & 83 & 241,48 & 0,0282 \\
14 & 0,0017 & 84 & 228,05 & 0,0342 \\
\hline
\end{tabular}


ANEXO VI - Valores do ensaio creep dinâmico na temperatura de $40{ }^{\circ} \mathrm{C}$

\begin{tabular}{cccc}
\hline \multicolumn{4}{c}{ Dinâmico $\mathbf{0 , 4} \mathbf{4 0 o C}$} \\
CP & Def. Total & MF & Icurva \\
\hline 1 & 0,0022 & 1732,8 & 0,3733 \\
2 & 0,0013 & 3023,4 & 0,2915 \\
3 & 0,0022 & 1753,7 & 0,3954 \\
4 & 0,0016 & 2170,5 & 0,3858 \\
5 & 0,0009 & 3625,7 & 0,2020 \\
6 & 0,0009 & 4043,8 & 0,1944 \\
7 & 0,0007 & 5123,5 & 0,2417 \\
8 & 0,0009 & 4088,6 & 0,1165 \\
9 & 0,0045 & 831,0 & 0,5184 \\
10 & 0,0047 & 758,2 & 0,5477 \\
11 & 0,0027 & 1305,2 & 0,4290 \\
12 & 0,0033 & 1068,8 & 0,4892 \\
13 & 0,0016 & 2220,9 & 0,2944 \\
14 & 0,0015 & 2411,1 & 0,2836 \\
15 & 0,0017 & 2034,7 & 0,3465 \\
16 & 0,0013 & 2780,0 & 0,3852 \\
\hline
\end{tabular}


ANEXO VII - Valores do ensaio creep dinâmico na temperatura de $50^{\circ} \mathrm{C}$

\begin{tabular}{cccc}
\hline \multicolumn{4}{c}{ Dinâmico $\mathbf{0 , 4} \mathbf{5 0 0 C}$} \\
$\mathbf{C P}$ & Def. Total & MF & Icurva \\
\hline 1 & 0,0069 & 567,0 & 0,5015 \\
2 & 0,0074 & 608,3 & 0,5922 \\
3 & 0,0083 & 442,3 & 0,6361 \\
4 & 0,0026 & 1380,0 & 0,4355 \\
5 & 0,0024 & 1514,3 & 0,4025 \\
6 & 0,0020 & 1869,0 & 0,4121 \\
7 & 0,0023 & 1565,8 & 0,3962 \\
8 & 0,0025 & 1457,7 & 0,4288 \\
9 & 0,0281 & 130,4 & 0,4860 \\
10 & 0,0248 & 144,9 & 0,9416 \\
11 & 0,0047 & 768,9 & 0,4857 \\
12 & 0,0033 & 1103,6 & 0,5593 \\
13 & 0,0060 & 635,3 & 0,5595 \\
14 & 0,0064 & 572,2 & 0,6000 \\
\hline
\end{tabular}

